\title{
JOIN THE CLUB: THE IMPLICATIONS OF THE ANTI-COUNTERFEITING TRADE AGREEMENT'S ENFORCEMENT MEASURES FOR CANADIAN COPYRIGHT LAW
}

\author{
ELIZABETH F JUDGE* AND SALEH AL-SHARIEH ${ }^{* *}$
}

\begin{abstract}
The Anti-Counterfeiting Trade Agreement (ACTA) is the most recent international agreement by which Canada and other countries have sought to strengthen the protection and enforcement of intellectual property rights. While it was originally feared that ACTA would impose obligations that are in tension with the principles of Canadian copyright law, the final outcome of the ACTA negotiations moderated or removed many of the most controversial provisions in the agreement and thus has alleviated many of the concerns about the impact of ACTA on Canadian copyright law. Canada has taken the first steps toward satisfying ACTA's copyright obligations with Bill C11, the Copyright Modernization Act, which addresses some of the agreement's digital copyright measures. Some legislative change still remains before Canada will have fully met ACTA's copyright obligations, in particular to enhance the powers of customs and border authorities to enforce intellectual property rights. This article discusses ACTA's evolution, negotiations, final text, and the extent of its rightsholder orientation. It then details the differences between ACTA's provisions and the current Canadian Copyright Act, as amended by the Copyright Modernization Act, identifies which obligations in ACTA require further amendment, and suggests how these obligations may best be implemented to reflect important values and principles underlying Canadian copyright law.
\end{abstract}

L'Accord commercial anti-contrefaçon (ACAC) est la toute dernière entente internationale dans le cadre de laquelle le Canada et d'autres pays cherchent à renforcer la protection et l'exécution des droits de propriété intellectuelle. Bien qu'on craignît à l'origine que l'ACAC impose des obligations tendues par rapport aux principes de la loi canadienne sur le droit d'auteur, l'aboutissement des négociations de l'ACAC a modéré nombre des dispositions les plus controversées de l'ACAC ou s'en est éloigné et ainsi a calmé les inquiétudes sur l'effet de l'ACAC sur la loi canadienne sur le droit d'auteur. Avec le projet de loi $C-11$, Loi sur la modernisation du droit d'auteur, le Canada a fait les premiers pas vers la conformité avec les obligations de l'ACAC à cet égard. La nouvelle loi aborde certaines mesures de l'ACAC qui ont trait au droit d'auteur dans un monde numérique.D'autres modifications législatives sont nécessaires pour que le Canada se conforme entièrement aux obligations de l'ACAC; il faudra tout particulièrement rehausser le pouvoir de la Douane et des autorités frontalières pour faire respecter les droits sur la propriété intellectuelle. Cet article porte sur les négociations et le texte final de l'ACAC ainsi que sur la portée de l'orientation des détenteurs de droits. Il décrit aussi en détail les différences entre les dispositions de l'ACAC et la loi canadienne sur le droit d'auteur actuelle qui est devenue la Loi sur la modernisation du droit d'auteur, identifie les obligations de l'ACAC qui nécessitent des modifications et suggèrent des moyens de mettre en œuvre ces obligations de manière à refléter les valeurs et principes importants du droit d'auteur canadien.

\section{TABLE OF CONTENTS}

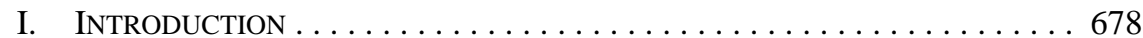

II. THE EVOLUTION OF ACTA . . . . . . . . . . . . . . . 683

III. ACTA's CONTENT AND RIGHTS-HOLDER ORIENTATION $\ldots \ldots \ldots \ldots 689$

A. ACTA's TRIPS-PLUS MODEL $\ldots \ldots \ldots \ldots \ldots \ldots 6 . \ldots \ldots$

B. ACTA's REGIME SHIFT $\ldots \ldots \ldots \ldots \ldots \ldots \ldots . \ldots \ldots \ldots$

C. ACTA's DisCOURSE . . . . . . . . . . . . . . . . . . . 694

* $\quad$ Elizabeth F. Judge is a Professor of Law at the Faculty of Law at the University of Ottawa. She is a member of the Centre for Law, Technology and Society and an affiliate member of the Institute for Science, Society and Policy at the University of Ottawa. We gratefully acknowledge support from the GEOIDE Network, the Social Sciences and Humanities Research Council of Canada, and the Law Foundation of Ontario.

** Saleh Al-Sharieh is a Doctoral Candidate at the Faculty of Law at the University of Ottawa. 
D. ACTA as a Minimum Standards AgreEment . . . . . . . . . 695

E. ASYMMETRY BETWEen INTELLECTUAL PROPERTy RightS

VERSUS DEFENCES, EXCEPTIONS, AND OTHER RightS . . . . . . . 698

IV. ACTA AND COPYRIGHT REFORM . . . . . . . . . . . . . . . . . . 699

V. THE IMPACT OF ACTA's LEGAL FRAMEWORK

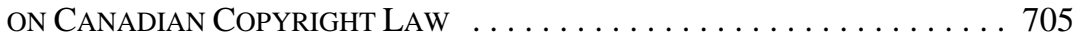

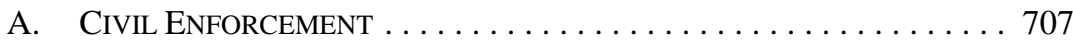

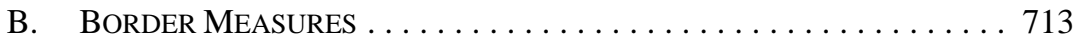

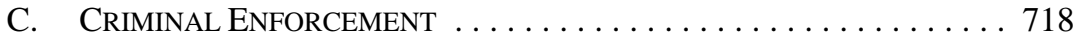

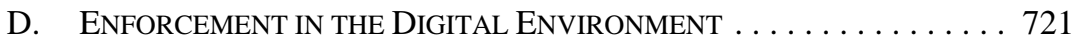

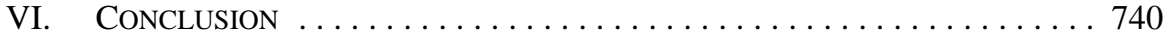

\section{INTRODUCTION}

At the same time that Canada's Parliament was debating amendments to modernize the Canadian Copyright Act, ${ }^{1}$ the Canadian government joined several nations in the negotiations for a new intellectual property agreement, the Anti-Counterfeiting Trade Agreement (ACTA). ${ }^{2}$ ACTA aims to enhance the enforcement of intellectual property rights and combat "counterfeit trademark goods" and "pirated copyright goods." ${ }^{3}$ Notably, ACTA is a plurilateral agreement negotiated only among select members of the World Trade Organization (WTO), ${ }^{4}$ consisting principally of countries with strong intellectual property portfolios who share a keen interest in strengthening enforcement against counterfeit and pirated goods and who are frustrated by the lack of international cooperation thus far. ${ }^{5}$ ACTA

RSC 1985, с C-42.

Anti-Counterfeiting Trade Agreement, Australia, Canada, the European Union, Japan, the Republic of Korea, Mexico, Morocco, New Zealand, Singapore, Switzerland, and United States, 1 May 2011 (signed by Canada on 10 October 2011), online: European Commission <http://trade.ec.europa.eu/doclib/ docs/2011/may/tradoc_147937.pdf> [ACTA]. Canada officially announced its intention to join the negotiations on 23 October 2007 and remained an active participant in all 11 rounds of ACTA negotiations, which came to an end in October 2010 in Tokyo, Japan. Foreign Affairs and International Trade Canada, "Anti-Counterfeiting Trade Agreement (ACTA)," online: Foreign Affairs and International Trade Canada <http://www.international.gc.ca/trade-agreements-accords-commerciaux/fo/ intellect_property.aspx?view $=\mathrm{d}>$.

ACTA, ibid, art 5(d):

counterfeit trademark goods means any goods, including packaging, bearing without authorization a trademark which is identical to the trademark validly registered in respect of such goods, or which cannot be distinguished in its essential aspects from such a trademark, and which thereby infringes the rights of the owner of the trademark in question under the law of the country in which the procedures set forth in Chapter II (Legal Framework for Enforcement of Intellectual Property Rights) are invoked [emphasis omitted].

Ibid, art 5(k):

pirated copyright goods means any goods which are copies made without the consent of the right holder or person duly authorized by the right holder in the country of production and which are made directly or indirectly from an article where the making of that copy would have constituted an infringement of a copyright or a related right under the law of the country in which the procedures set forth in Chapter II (Legal Framework for Enforcement of Intellectual Property Rights) are invoked [emphasis omitted].

These definitions are consistent with the definitions of the same terms in the World Trade Organization (WTO), Agreement on Trade-Related Aspects of Intellectual Property Rights, Annex 1C of the Marrakesh Agreement Establishing the World Trade Organization, 15 April 1994, WTO Doc LT/UR/A1C/IP/1, 33 ILM 1197, art 51, n 14(a)-(b), online: WTO <http://www.wto.org/english/docs_e/legal_ e/27-trips.pdf $>$ [TRIPS or TRIPS Agreement].

4 WTO, online: WTO < wWw.wto.org $>$.

5 Plurilateral agreements are open to only a limited number of countries, as distinct from multilateral agreements such as the WTO's TRIPS Agreement, supra note 3, to which all members of the WTO are parties. See ACTA, supra note 2, for a list of the nations that are signatories to ACTA as of October 2011. For a list of nations that signed ACTA after this article went to press, see the discussion in note 60, infra. 
aims to meet this objective by creating a new international legal framework of best practices for combating counterfeiting and piracy. The agreement establishes uniform standards for the enforcement of intellectual property rights through enhanced border measures, civil and criminal enforcement measures, specific practices for the digital environment, and increased international cooperation between enforcement agencies and right holders. ACTA's Preamble indicates that its member countries designed the agreement to address the cross-border trade problem of weak intellectual property rights enforcement by setting norms that would be taken up globally and not merely by its member nations. ${ }^{6}$

ACTA's scope encompasses intellectual property broadly defined and is co-extensive with the subject matter covered by TRIPS (namely, copyright and related rights, industrial design, trademarks, geographical indications, patents, integrated circuit topographies, and undisclosed information). ${ }^{7}$ ACTA's obligations apply generally to all intellectual property rights infringement, unless the agreement provides otherwise. Thus the agreement imposes an obligation on its parties to ensure that enforcement procedures are made available under national laws "so as to permit effective action against any act of infringement of intellectual property rights covered by this Agreement." ${ }^{8}$ However, the cumulative effect of ACTA's provisions is more limited in several key respects. First, a party has no obligation to apply measures to an intellectual property right if the party's national laws do not protect that right (for example, geographical indications). ${ }^{9}$ Second, ACTA's specific provisions on border measures, civil enforcement (including injunctions and damages), and criminal offences provisions are narrower in application; although the wording varies, the effect is that none of these sections is obligatory for patents and undisclosed information. ${ }^{10}$ Third, several provisions are further restricted in application to only "counterfeit trademark goods" and "pirated copyright goods," which are more narrowly defined than the categories of trademark or copyright infringement. ${ }^{11}$ Fourth, in the criminal enforcement section, parties are obliged only to provide criminal procedures and penalties for "wilful trademark counterfeiting or copyright or related rights piracy on a commercial scale," 12 and thus parties may decide whether to extend the criminal enforcement provisions to non-wilful, non-commercial, trademark and copyright infringements and to other intellectual property rights infringements.

See ACTA, ibid, Preamble, paras 1-2:

Noting that effective enforcement of intellectual property rights is critical to sustaining economic growth across all industries and globally;

Noting further that the proliferation of counterfeit and pirated goods, as well as of services that distribute infringing material, undermines legitimate trade and sustainable development of the world economy, causes significant financial losses for right holders and for legitimate businesses, and, in some cases, provides a source of revenue for organized crime and otherwise poses risks to the public [emphasis added].

$7 \quad$ Ibid, art 5(h): "all categories of intellectual property that are the subject of Sections 1 through 7 of Part II of the TRIPS Agreement."

ACTA, ibid, art 6.1.

Ibid, art 3.2.

Patents and undisclosed information are expressly excluded from the scope of the border measures provisions: ibid, art 13, n 6. Parties may exclude patents and undisclosed information from the scope of the civil enforcement provisions: ibid, s 2, n 2. Parties "shall” apply the criminal provisions "at least" to "wilful trademark counterfeiting or copyright or related rights piracy on a commercial scale," and thus parties could, but need not, include patents and undisclosed information in the scope of their criminal procedures and penalties: ibid, art 23.1 [emphasis added].

11 Ibid, art 5(d), sub verbo "counterfeit trademarked goods"; ibid, art 5(k), sub verbo "pirated copyrighted goods.” See also TRIPS, supra note 3, art 51, n 14 (same definitions for these terms). ACTA, ibid, art 23.1 [emphasis added]. 
From the start of negotiations in 2007, ACTA has been assailed by criticisms, especially from academics, civil society groups, and developing countries. Their concerns particularly emphasized the lack of transparency in the agreement's negotiating procedures, the lack of consultation with the public and lack of access for the media, the selectiveness of the participating countries (which comprise mainly developed countries with strong intellectual property portfolios and exclude almost all newly industrialized and developing countries, including the notable omission of Brazil, Russia, India, and China), the negotiating countries' decision to negotiate and administer the resulting agreement apart from existing multilateral forums such as the WTO, and the content of the agreement's obligations. ${ }^{13}$

It no doubt stoked anxiety among observers that the first official draft of the agreement was issued only after the eighth round of negotiations, following nearly two years of negotiations. ${ }^{14}$ As a July 2011 study on ACTA by the European Parliament observed, the prolonged secrecy "was to prove a significant handicap to public understanding and support for the treaty" because it "allowed significant misapprehensions to develop, while making it difficult for negotiators to communicate the actual scale and content of what was being achieved."15

Another troubling aspect for many observers was that the agreement signals yet another regime change by certain developed countries. As Laurence Helfer details, the WTO's TRIPS Agreement ${ }^{16}$ constituted a regime change from the soft power of the World Intellectual Property Organization (WIPO) ${ }^{17}$ to the enforcement mechanisms of the WTO. ${ }^{18}$ However, net intellectual property exporters have grown increasingly pessimistic about the likelihood that vigorous norms for the enforcement of intellectual property rights will be established (and conformed to) by the member nations in either WIPO or the WTO, given the voting

In Canada, see e.g. Letter from Charlie Angus, MP, to Peter Van Loan, Minister of International Trade (26 January 2010), online: Straight.com <http://www.straight.com/article-282136/vancouver/ndp-mpcharlie-angus-raises-questions-about-anticounterfeiting-trade-agreement>; Letter from David Fewer, Canadian Internet Policy and Public Interest Clinic (CIPPIC), to the Department of Foreign Affairs and International Trade Canada (DFAIT) (30 April 2008), online: CIPPIC <http://www.cippic.ca/uploads/ CIPPIC_LT_DFAIT-ACTA-30\%20April\%2008.pdf >; Canadian Library Association (CLA), "Brief to Foreign Affairs and International Trade Canada on the Anti-Counterfeiting Trade Agreement" (30 April 2008), online: CLA <http://www.cla.ca/AM/Template.cfm?Section=News1\&CONTENTID=5012\& TEMPLATE=/CM/ContentDisplay.cfm>; Michael Geist, "The ACTA Threat: My Talk on Everything You Need To Know About ACTA, But Didn’t Know To Ask” (12 November 2009), online: Michael Geist <http://www.michaelgeist.ca/content/view/4530/408/>. See also David S Levine, "Transparency Soup: The ACTA Negotiating Process and ‘Black Box’ Lawmaking” (2011) 26:3 Am U Int’l L Rev 811 (arguing that had ACTA negotiations been more transparent, both the general public and rights holders would have benefited more because transparency would have saved the resources wasted on maintaining secrecy, produced a more balanced substance of ACTA, and decreased opposition to the agreement). Anti-Counterfeiting Trade Agreement, Public Predecisional/Deliberative Draft, April 2010, online: USTR < http://www.ustr.gov/webfm_send/1883> [ACTA: April 2010 Consolidated Text].

15 Directorate-General for External Policies of the Union, European Parliament, The Anti-Counterfeiting Trade Agreement (ACTA): An Assessment (July 2011) at 6, online: La Quadrature du Net <http://www. laquadrature.net/files/INTA\%20-\%20ACTA\%20assessment.pdf > [ACTA Assessment].

16 TRIPS, supra note 3.

17 World Intellectual Property Organization (WIPO), online: WIPO <http://www.wipo.int/portal/index. html.en>.

18 Laurence R Helfer, "Regime Shifting: The TRIPS Agreement and New Dynamics of International Intellectual Property Lawmaking” (2004) 29:1 Yale J Int'l L 1 at 14-20 [Helfer, “Regime Shifting”] (defining regime shifting as "an attempt to alter the status quo ante by moving treaty negotiations, lawmaking initiatives, or standard setting activities from one international venue to another” (ibid at 14), and stating the factors that motivated developed countries to shift negotiating intellectual property norms from WIPO to the WTO: "The first [factor] related to dissatisfaction with treaty negotiations hosted by WIPO. The second focused on institutional features of the GATT that facilitated adoption of more stringent intellectual property protection standards that these states favored” (ibid at 20)). 
strength of developing and newly industrialized countries in those forums. ${ }^{19}$ Thus, the new suspicion about regime change is that the cadre of developed countries negotiating ACTA have grown increasingly dissatisfied with the enforcement mechanisms available through the WTO and are moving away from the international intellectual property consensus that TRIPS was supposed to represent, instead gravitating toward an untested forum in ACTA. ${ }^{20}$

ACTA's negotiations took place outside the known forums for intellectual property protection norm-setting, such as WIPO and the WTO, where a certain level of transparency, democracy, and accountability is supported. ${ }^{21}$ Not only was ACTA negotiated independently of the auspices and norms of WIPO and the WTO, but it also will be administered through a newly created body. ${ }^{22}$ Unlike the previous major multilateral intellectual property agreements that are administered within the established forums of either WIPO (which administers the oldest copyright and industrial property treaties - the Berne Convention ${ }^{23}$ and the Paris Convention ${ }^{24}$ ) or the WTO (which administers TRIPS), ACTA will create its own governing body, whose norms and practices at this early stage are inchoate and difficult to predict. The ACTA Committee, on which all parties have a representative and which makes all decisions by consensus, has a limited mandate. ${ }^{25}$ The Committee will consider matters related to the agreement's implementation and operation, may endorse best practices, and may share information with third parties about reducing intellectual property infringements. ${ }^{26}$ However, the Committee is explicitly not a dispute resolution forum. ${ }^{27}$ Even though dispute resolution would seem to be integral to ACTA's goal of strengthening enforcement, the agreement diverges from the practice in regional and bilateral trade agreements of providing

In WIPO, issues pertaining to the enforcement of intellectual property rights are discussed only by an advisory committee. On the mandate of the WIPO Advisory Committee on Enforcement, see WIPO, General Assembly, Report adopted by the Assembly (held 23 September to 10 October 2002), WO/GA/28/7, 28th Sess, online: <http://www.wipo.int/meetings/en/doc_details.jsp?doc_id=14890>. For the more proactive approach used by developing countries at the WTO to influence intellectual property rights enforcement norms, see WTO, TRIPS Council, Minutes of Meeting (held on 8-9 June 2010), IP/C/M/63. See also Peter K Yu, “TRIPS and Its Achilles’ Heel,” (2011) 18:2 J Intell Prop L 479. Jeffery Atik, “ACTA and the Destabilization of TRIPS” in Hans Henrik, Jeffery Atik \& Tu Thahn Nguyen, eds, Sustainable Technology Transfer [Kluwer, forthcoming] ch 6, online: Social Science Research Network (SSRN) <http://ssrn.com/ abstract=1856285>.

21 See Eddan Katz \& Gwen Hinze, "The Impact of the Anti-Counterfeiting Trade Agreement on the Knowledge Economy: The Accountability of the Office of the U.S. Trade Representative for the Creation of IP Enforcement Norms Through Executive Trade Agreements” (2009) 35 Yale J Int'l L (Online) 24 at 26, online: Yale Journal of International Law < http://www.yjil.org/online>; Robin Gross, “IP Justice White Paper on the Proposed Anti-Counterfeiting Trade Agreement (ACTA)" (25 March 2008) at 5, online: IP Justice <http://ipjustice.org/wp/wp-content/uploads/IPJustice_ACTA-white-papermar2008.pdf $>$ [Gross, "On the Proposed ACTA"]. Many commentators had criticized moving the intellectual property norm-setting from WIPO to the WTO; this criticism is also applicable to ACTA. See TN Srinivasan, Developing Countries and the Multilateral Trading System: From the GATT to the Uruguay Round and the Future (Boulder, Colo: Westview Press, 1998) (arguing, inter alia, that there was no real rationale for dealing with intellectual property issues under the trade umbrella in light of the presence of WIPO, the organization of the most relevant expertise); Peter M Gerhart, "The Tragedy of TRIPS” (2007) 1 Michigan State Law Review 143 at 183 (arguing that the WTO is not the right forum for making intellectual property laws since no balance between rights holders and users can be achieved in that forum due to wealth differences "within countries and between countries”). See ACTA, supra note 2, ch V especially Article 36 on the ACTA Committee. Berne Convention for the Protection of Literary and Artistic Works, 9 September 1886, 828 UNTS 221 (amended on 28 September 1979), online: WIPO <http://www.wipo.int/treaties/en/ip/berne/trtdocs wo001.html> [Berne Convention].

Paris Convention for the Protection of Industrial Property, 20 March 1883, 828 UNTS 305 (as amended 28 September 1979), online: WIPO <http://www.wipo.int/treaties/en/ip/paris/trtdocs_wo020.html> [Paris Convention].

ACTA, supra note 2 , art 36.

Ibid, arts 36.1-36.4.

Ibid, art 36.11 provides: "For greater certainty, the Committee shall not oversee or supervise domestic or international enforcement or criminal investigations of specific intellectual property cases.” 
detailed rules about dispute procedures, and there are few indications as to the actual mechanisms for dispute resolution that members should pursue. Each ACTA party is required to "designate a contact point to facilitate communications between the Parties" about ACTA matters. ${ }^{28}$ Parties may request "consultations” with another party about any matter affecting the agreement's implementation, to which request the other party "shall accord sympathetic consideration ..., provide a response, and afford adequate opportunity to consult." ${ }^{29}$ These consultations, including the parties' respective positions, are confidential, though by mutual consent the parties may notify the Committee of the consultation results. ${ }^{30}$ The consultations are also without prejudice to the parties' rights and positions in any other proceeding, including WTO dispute settlements. ${ }^{31}$ Parties may take a dispute to a court or tribunal, but the agreement leaves it to the parties to choose a forum.

Finally, the strengthened enforcement of intellectual property rights incorporated in ACTA is thought to go hand-in-hand with a broader maximalist agenda for the increased substance of intellectual property rights and to indicate the negotiating countries' desire to elevate intellectual property protection and enforcement beyond the levels of TRIPS. ${ }^{32}$ ACTA emphasizes that it is an agreement about enforcement of intellectual property rights. Hence, the Preamble's first statement notes that the "effective enforcement of intellectual property rights is critical to sustaining economic growth across all industries and globally." 33 Further, Article 3.1 expressly states that the agreement "shall be without prejudice" to a member's laws "governing the availability, acquisition, scope, and maintenance of intellectual property rights." 34 Although ACTA is intended only to strengthen the enforcement of intellectual property rights without expanding the intellectual property rights themselves, which are set out in national laws, its effect may be that ACTA not only strengthens enforcement but also adds to the rights that copyright owners can wield. Assessed from a Canadian perspective, there are arguably provisions in ACTA that constitute an enlargement of substantive intellectual property rights, such as the sections protecting technological protection measures (TPMs) and rights management information (RMI). ${ }^{35}$

However, it is also important to emphasize that ACTA incorporates many safeguards to protect those who are subject to the agreement's enforcement mechanisms. These provisions have not been as emphasized in commentary about the agreement, which may in part be attributable to ACTA's drafting style. Whereas TRIPS tends to reiterate protections, defences, and exceptions alongside the specific rights throughout the agreement, ACTA mostly includes safeguards in its Preamble and the initial provisions in Section 1. These safeguards are generally applicable to any of the enforcement sections, but, especially in the civil and criminal enforcement sections, they tend not to be repeated in the individual sections that

Ibid, art 37.

Ibid, art 38.1.

Ibid, arts 38.2-38.3.

Ibid, art 38.2.

See e.g. Global Congress on Intellectual Property and the Public Interest, “The Washington Declaration on Intellectual Property and the Public Interest” (conclusions from the Global Congress on Intellectual Property and the Public Interest held at American University Washington College of Law, 25-27 August 2011) at 4, online: Infojustice <http://infojustice.org/washington-declaration> (stating that "[t]he maximalist intellectual property agenda includes a push at all levels for stronger enforcement”).

ACTA, supra note 2, Preamble, para 1 [emphasis added].

Ibid, art 3.1.

Ibid, arts 27.5-27.7. 
follow. ACTA, for example, makes explicit references to privacy, confidentiality, balancing, procedural rights, and avoiding barriers to trade. ${ }^{36}$ Thus, although ACTA largely omits illustrating or contextualizing how these general obligations apply to each enforcement section, which is especially true in the civil and criminal enforcement sections, it is incumbent on member states to ensure that these safeguards are nonetheless carefully considered when implementing ACTA's specific obligations.

In this article, we consider the implications for Canada's Copyright Act if ACTA should come into force and Canada as a signatory ratify the agreement. The article thus does not address ACTA's impact on Canadian laws on trademark, patents, or other intellectual property rights. This article is divided into five parts: following this introduction, Part II analyzes the origins and evolution of ACTA; Part III discusses the content of the agreement and the scope of its rights-holder orientation; Part IV discusses the guiding principles of the Canadian Copyright Act and copyright reform process; and Part V evaluates the implications of ACTA's legal framework on Canadian copyright law. At the time that Canada signed ACTA, amendments to the Copyright Act were required before Canada could consent to be bound by the treaty by depositing an instrument of ratification. The fifth part of this article details the differences between ACTA's provisions and the current Canadian Copyright Act, as amended by the proposed Copyright Modernization $A c t,{ }^{37}$ identifies which obligations in ACTA require further amendment before Canada will be in compliance, and suggests how these amendments may best be implemented to reflect important values and principles underlying Canadian copyright law.

\section{THE EVOLuTION OF ACTA}

One of the most frequent complaints against ACTA targets the club-like nature of the negotiating countries as, from its inception, ACTA's insiders have been a select group of developed countries with strong intellectual property portfolios. Introducing an anticounterfeiting trade agreement was originally a Japanese idea, which overlapped with the desire of other like-minded countries for stronger enforceability of intellectual property rights as expressed in different initiatives, forums, and events. ${ }^{38}$ Japan, the United States, the EU, Canada, and Switzerland carried out initial discussions between 2006 and 2007, and the

See e.g. ibid, Preamble, paras 5-6; arts 1, 2.3, 4, 6.2-6.3, 27.2-27.4, 27.8.

Bill C-11, An Act to amend the Copyright Act, 1st Sess, 41st Parl, No 60 (first reading 29 September 2011), [Bill C-11 or Copyright Modernization Act].

38 See e.g. Global Congress Combating Counterfeiting \& Piracy (Global Congress), “The Second Global Congress on Combating Counterfeiting and Piracy: The Lyon Declaration” (15 November 2005), online: Global Congress <http://www.ccapcongress.net/archives/Lyon/files/OutcomesStatement20051115.pdf> (considering Japan's proposal for a new international treaty addressing counterfeiting and piracy); G8 Summit, “Combating IPR Piracy and Counterfeiting” (St. Petersburg, Russia, 16 July 2006), online: G8 <http://en.g8russia.ru/docs/15.html> (reaffirming the group's commitment to fight piracy and counterfeiting); Office of the US IPR Coordinator, "Bush Administration Strategy for Targeting Organized Piracy" (September 2007), online: EFF <http://www.eff.org/sites/default/fiels/filenode/ EFF_PK_v_USTR/foia-ustr-acta-response1-doc13.pdf > (discussing the “Stop!” initiative, which was launched by the Bush administration in 2004 to harmonize the efforts of a number of federal agencies and engage the American industry and the US trading partners in strengthening the enforcement of intellectual property rights in the US and abroad); EC, "Strategy for the enforcement of intellectual property rights in third countries” [2005] OJ, C129/3 (26 May 2005), online: EC <http://trade.ec.europa. eu/doclib/docs/2010/december/tradoc_147070.pdf > (proposing a set of actions to overcome the problem of intellectual property violations). For a complete account of ACTA's origins, see Peter K Yu, "Six Secret (and Now Open) Fears of ACTA,” (2011) 64:3 SMU L Rev 975 [Yu, “Six Secret Fears”]. 
official launch of the negotiations for ACTA was in June 2008. ${ }^{39}$ As the rounds of negotiations progressed, the roster expanded to include more countries, including Australia, Mexico, Morocco, New Zealand, Singapore, and the Republic of Korea. ${ }^{40}$ The goal of the participating countries was to reach an agreement by the end of $2010 .{ }^{41}$ The eleventh and final round of negotiations in Tokyo took place from 23 September to 2 October 2010 with participation from 38 parties, including Australia, Canada, the EU (represented by the European Commission and the EU Presidency (Belgium) and the EU Member States), Japan, South Korea, Mexico, Morocco, New Zealand, Singapore, Switzerland, and the US. ${ }^{42}$

In the first seven rounds of the negotiations, held between June 2008 and January 2010, officials of the participating countries negotiated the treaty under a veil of secrecy, ${ }^{43}$ with the US and EU explaining that, for efficiency, it was normal and "accepted practice” in the early stages of international negotiations that economic matters not be carried out in public and for

See Office of the United States Trade Representative (USTR), “The Anti-Counterfeiting Trade Agreement - Summary of Key Elements Under Discussion” (6 November 2009), online: USTR <http://www.ustr.gov/webfm_send/1479> [USTR, "Summary of Key Elements”]; USTR, Press Release, “Ambassador Schwab Announces U.S. Will Seek New Trade Agreement to Fight Fakes” (23 October 2007), online: USTR <http://www.ustr.gov/ambassador-schwab-announces-us-will-seek-new-tradeagreement-fight-fakes>.

40 See USTR, "Summary of Key Elements," ibid. Some countries that participated in first rounds of the negotiations, specifically Jordan, the United Arab Emirates and Uruguay, dropped out; see "EU ACTA Negotiator Confirms EU Wants Patent Provisions In ACTA” (2009) 27:18 Inside US Trade 11, online: Inside US Trade <http://lists.essential.org/pipermail/a2k/2009-May/004427.html>; Charles R McManis, “The Proposed Anti-Counterfeiting Trade Agreement (ACTA): Two Tales of A Treaty” (2009) 46:4 Hous L Rev 1235 at 1239 [McManis, “The Proposed ACTA”].

41 See USTR, “Summary of Key Elements,” supra note 39.

42 The full list of participants in the negotiations for the final agreement is: Australia, Austria, Belgium, Bulgaria, Canada, Cyprus, Czech Republic, Denmark, Estonia, EU, Finland, France, Germany, Greece, Hungary, Ireland, Italy, Japan, Korea, Latvia, Lithuania, Luxembourg, Malta, Mexico, Morocco, Netherlands, New Zealand, Poland, Portugal, Romania, Singapore, Slovakia, Slovenia, Spain, Sweden, Switzerland, United Kingdom, and the US. ACTA, supra note 2, art 39, n 17. According to the "Technology Balance of Payments," which is issued by the Organization for Economic Co-operation and Development (OECD) and which measures "disembodied international technology transfers: licence fees, patents, purchases and royalties paid, know-how, research and technical assistance,” the EU, Austria, Norway, Czech Republic, Denmark, Finland, France, Germany, Italy, Japan, Netherlands, Portugal, Sweden, UK, Canada, and US are net exporters of technology. On the other hand, Australia, New Zealand, Korea, Mexico, Spain, Greece, Slovakia, Ireland, Poland, Luxembourg, Hungary and Switzerland are net importers of technology; OECD, Measuring Globalisation: OECD Economic Globalisation Indicators 2010 (OECD Publishing, 2010) at 128-29. Countries with a negative technology balance of payments might have participated in ACTA negotiations due to their high involvement in trade with the US and Japan, as is the case for Mexico, Australia, and New Zealand, or due to the influence of their membership in the EU.

43 Negotiators of ACTA agreed that all the documents exchanged in the course of the negotiations will be classified as “Confidential Foreign Government Information”; Memorandum for All Anti-Counterfeiting Trade Agreement Negotiators from Warren Maruyama, General Counsel, USTR (8 February 2008), online: Electronic Frontier Foundation (EFF) <http://www.eff.org/files/filenode/EFF_PK_v_USTR/ maruyama_decl.pdf $>$. Trying to get information on ACTA's negotiations, the EFF and Public Knowledge (PK) submitted a request to the USTR, under the US Freedom of Information Act, 5 USC § 552, seeking the release of records on the proposed agreement and the negotiations pertinent thereto. The request was ignored by the USTR and, as a result, the EFF and PK initiated a suit against the USTR on 17 September 2008 requesting that the Court order the USTR to respond to their request; see EFF, "AntiCounterfeiting Trade Agreement (ACTA),” online: EFF < http://www.eff.org/cases/eff-and-publicknowledge-v-ustr>; Electronic Frontier Foundation $v$ Office of the United States Trade Representative (Civil Action 08-1599 (DDC)) (17 September 2008), online: JD Supra <http://www.jdsupra.com/post/ documentViewer.aspx?fid=0a48a9c9-adea-4d21-b192-2fe34a88412b>. Eventually, the EFF and PK dropped the suit on the ground that courts have little power to force the executive branch to release documents classified confidential on national security grounds and after the Obama administration showed its support for the classification; "EFF and Public Knowledge Reluctantly Drop Lawsuit for Information About ACTA” (17 June 2009), online: EFF <https://www.eff.org/press/archives/2009/ 06/17>. 
negotiators to adhere to "a certain level of discretion." ${ }^{44}$ No official text of the treaty was released throughout these seven rounds; the countries merely distributed a document summarizing the major elements being discussed under the treaty ${ }^{45}$ while rejecting the reliability of any leaked draft text of the treaty. ${ }^{46}$ This early lack of transparency in ACTA's negotiations triggered severe criticism from civil society and academics and also caused tension between executive and legislative branches of government. ${ }^{47}$ For example, the European Parliament approved a resolution calling upon the EC to publicly reveal all documents pertinent to ACTA negotiations and to promote adherence to transparency with respect to the negotiations and their outcome. ${ }^{48}$

Following the European resolution and the proliferation of leaks of ACTA documents, the most significant of which was the 18 January 2010 treaty draft, ${ }^{49}$ the negotiating countries released an official draft text of the treaty after the eighth round of the negotiations held in Wellington, New Zealand, in April 2010. ${ }^{50}$ Unlike the January 2010 leak of the agreement, the first official draft of ACTA did not identify the positions of the countries with respect to the controversial provisions; instead, each different proposition of the participating countries was left in square brackets without reference to the country to which this proposition belonged. In the ninth round of negotiations held in Lucerne, Switzerland, from 28 June to 1 July 2010, the participating countries did not release a new draft of the agreement;

EC, "The Anti-Counterfeiting Trade Agreement Fact Sheet" (November 2008) at 4, online: EC <http:// trade.ec.europa.eu/doclib/docs/2008/october/tradoc_140836.11.08.pdf> [EC, "Fact Sheet"]; USTR, "Summary of Key Elements," supra note 39; see contra, EFF et al, Memorandum, "Transparency in Negotiations Involving Norms for Knowledge Goods: What Should USTR Do?” (21 July 2009) at Attachment 1, “ACTA is Secret. How Transparent are Other Global Norm Setting Exercises?” online: Knowledge Ecology International < http://www.keionline.org/misc-docs/4/attachment1_transparency_ ustr.pdf>.

45 USTR, “Summary of Key Elements,” ibid.

$46 \quad$ EC, "Fact Sheet," supra note 44.

47 See e.g. Roberto D'Erme et al, “Opinion of European Academics on Anti-Counterfeiting Trade Agreement,” (open for signature until 7 February 2011, when it was submitted to the European Parliament and other relevant European and national institutions), online: Institute for Legal Informatics <http://www.iri.uni-hannover.de/tl_files/pdf/ACTA_opinion_200111_2.pdf> (reviewing the 3 December 2010 draft) ["Opinion of European Academics”]; Sean Flynn, "Statement to the Obama Administration on the Constitutional Problem with ACTA,” available online: Infojustice <http://infojustice.org/ archives/1115>; Margot Kaminski, "The Origins and Potential Impact of the Anti-Counterfeiting Trade Agreement (ACTA)” (2009) 34:1 Yale J Int'l L 247 at 247, describing ACTA, due to its lack of transparency, as "a black box that could contain a bomb”; Michael Geist, “ACTA Guide, Part Three: Transparency and ACTA Secrecy” (27 January 2010), online: Michael Geist < http://www.michaelgeist. $\mathrm{ca} /$ content/view/4737/125/> (summarizing the public concern over the secrecy of ACTA, identifying the sources of this secrecy, and arguing that secrecy is not the standard in negotiations involving international norms setting); James Love, "Transparency of FTAA Negotiations, Compared to ACTA" (7 December 2009), online: Knowledge Ecology International <http://keionline.org/node/715> (arguing that it is not the standard to negotiate treaties in secret); Robert Weissman, "Secret Counterfeiting Treaty Public Must be Made Public, Global Organizations Say” (15 September 2008), online: Essential Action $<$ http://www.essentialaction.org/access/?p=153>.

$48 \quad$ European Parliament, "European Parliament resolution of 10 March 2010 on the transparency and state of play of the ACTA negotiations" (10 March 2010), online: European Parliament <http://www. europarl.europa.eu/sides/getDoc.do?pubRef=-//EP//TEXT+TA+P7-TA-2010-0058+0+DOC+XML +V0//EN> [European Parliament, "Resolution of 10 March 2010”]. The European Parliament had earlier called upon the European Commissioner to make available all the documents relating to the ACTA negotiations; see "Access to documents: The European Parliament demands more transparency" (3 November 2009), online: European Parliament <http://www.europarl.europa.eu/news/expert/infopress_ page/019-51409-068-03-11-902-20090310IPR51408-09-03-2009-2009-false/default_es.htm>. online: La Quadrature du Net <http://www.laquadrature.net/files/201001_ACTA.pdf> [ACTA: January 2010 Leaked Draft].

50 ACTA: April 2010 Consolidated Text, supra note 14. 
however, a major leak of the draft resulting from that round shortly followed.${ }^{51}$ Similarly, absent an official release of the agreement at the end of the tenth round of the negotiations, another leak of the draft became available..$^{22}$ The 6 October 2010 release of an official text, soon after the conclusion of the final round of negotiations held in Tokyo, ended the series of ACTA text leaks. ${ }^{53}$ According to the negotiating countries, there were still a "small number of outstanding issues that require[d] further examination in their own countries with a view to finalizing the text of the agreement as promptly as possible." ${ }^{.54}$ After these issues were resolved, a text was released on 15 November $2010,{ }^{55}$ although this text still needed to go through a legal review. Upon completion of the legal review three weeks after, a final text of ACTA with a date of 3 December 2010 was released. ${ }^{56}$ However, that text has been succeeded by yet another one, formally adopted by participants on 15 April 2011, which removed the December 2010 date and moved the signature window two months later. ${ }^{57}$

This final text provides that ACTA became open for signature on 1 May 2011 and will remain so until 1 May 2013 for negotiating participants and other WTO members to whom the participants agree "by consensus." ${ }^{58}$ On 1 October 2011, at a signing ceremony in Tokyo, Canada, along with Australia, Korea, Japan, Morocco, New Zealand, Singapore, and the US, became the first signatories to the agreement. ${ }^{59}$ None of the EU member states nor Mexico joined that initial group of signatories, although in a joint statement the EU, Mexico, and Switzerland affirmed their support for the agreement and their intentions to sign "as soon as practicable." ${ }^{\circ 0}$ ACTA states that the agreement will "enter into force thirty days after ... the sixth instrument of ratification, acceptance, or approval" is deposited by any of the signatories ${ }^{61}$ For a signatory depositing its ratification, acceptance, or approval after this

Anti-Counterfeiting Trade Agreement, Informal Predecisional/Deliberative Draft (1 July 2010), online: La Quadrature du Net <http://www.laquadrature.net/files/acta_consolidatedtext_EUrestricted130710. pdf> [ACTA: July 2010 Leaked Draft]. online: Knowledge Ecology International < http://keionline.org/sites/default/files/acta_aug25_dc.pdf > [ACTA: August 2010 Leaked Draft].

Anti-Counterfeiting Trade Agreement, Consolidated Text (2 October 2010), online: USTR <http:// www.ustr.gov/webfm_send/2338> [ACTA: October 2010 Consolidated Text].

See USTR, Press Release, "Statement from Ambassador Ron Kirk Regarding the Public Release of ACTA Text” (October 2010), online: USTR <http://www.ustr.gov/about-us/press-office/pressreleases/2010/october/statement-ambassador-ron-kirk-regarding-public-rel> . USTR, Previous ACTA Texts, online: USTR <http://www.ustr.gov/trade-topics/intellectual-property/ anti-counterfeiting-trade-agreement-acta/previous-acta-texts $>$. Anti-Counterfeiting Trade Agreement (3 December 2010), online: USTR <http://www.ustr.gov/web fm_send/2417> [ACTA: December 2010].

ACTA, supra note 2.

Ibid, art 39. After the expiration of this period, WTO member states may apply to accede to ACTA according to art 43.

59 Department of Foreign Affairs and International Trade Canada (DFAIT), News Release, "Canada Signs Historic Anti-Counterfeiting Trade Agreement," (30 September 2011), online: DFAIT <http://www. international.gc.ca/media_commerce/comm/news-communiques/2011/280. aspx?lang=eng\&view=d>. "Joint Press Statement of the Anti-Counterfeiting Trade Agreement Negotiating Parties," Press Release (1 October 2011), online: METI <http://www.meti.go.jp/english/press/2011/0930_04.html>. After this article went to press, ACTA attracted additional signatories. On 16 December 2011, The Council of the European Union adopted a decision authorizing its member states to sign ACTA. Council of the European Union, Press Release (15-16 December 2011), online: <http://www.consilium.europa.eu/ uedocs/cms_data/docs/pressdata/en/agricult/127031.pdf>. On 26 January 2012, the EU and 22 of its member states (Austria, Belgium, Bulgaria, Czech Republic, Denmark, Finland, France, Greece, Hungary, Ireland, Italy, Latvia, Lithuania, Luxemburg, Malta, Poland, Portugal, Romania, Slovenia, Spain, Sweden, and the United Kingdom) signed ACTA. "Signing Ceremony of the EU for the AntiCounterfeiting Trade Agreement (ACTA) (Outline)” (26 January 2012), online: <http://www.mofa.go.jp/ policy/economy/i_property/acta1201.html $>$. The EU countries that did not sign ACTA at that time were Germany, the Netherlands, Estonia, Cyprus and Slovakia. ACTA, supra note 2, art 40.1. 
date, the agreement will enter into force as to that signatory 30 days after that signatory's deposit of its instrument. ${ }^{62}$ Even though more than six parties have already signed the agreement, ACTA is not yet in force because most countries require that the agreement be ratified, which in turn requires that any necessary domestic legislative changes first be enacted.

Giving force to ACTA seems to be as controversial as its multiple rounds of negotiations. In the US, the Obama administration's intention to treat the agreement as a "sole executive agreement," which, unlike a treaty, does not need to be approved by Congress, has been criticized on constitutional grounds. ${ }^{63}$ Additionally, some EU Parliamentarians tabled a motion for a resolution to request the opinion of the European Court of Justice on whether or not ACTA is compliant with EU intellectual property law. ${ }^{64}$ Likewise in Canada, the Report of the Standing Committee on Canadian Heritage examining ACTA expressed caution that the agreement's implementation should not affect Canada's existing international obligations nor infringe the purview of domestic policy. The Report's third recommendation

calls on the Government of Canada to ensure that ... Canada's commitments to the implementation of the Anti-Counterfeiting Trade Agreement (ACTA) are limited to the agreement's focus on combating international counterfeiting and commercial piracy efforts; and that the Government of Canada retains the right to maintain domestic copyright policies that have been developed within the framework of its commitments to the World Intellectual Property Organization and the Berne Convention. ${ }^{65}$

Moreover, given that Canada signed the WIPO Copyright Treaty (WCT) ${ }^{66}$ and WIPO Performance and Phonograms Treaty, ${ }^{67}$ collectively referred to as the "WIPO Internet Treaties,"68 back in 1997 but did not enact amendments to ratify them until the reintroduction of the Copyright Modernization Act in 2011, some speculation is warranted as to whether ACTA will similarly languish between the signatory and ratification stage.

See Sean Flynn et al, ACTA's Constitutional Problem: Submission of Legal Academics to the Office of the United States Trade Representative Economic and Trade (USTR-2010-0014) at 12, online: Infojustice <http://infojustice.org/wp-content/uploads/2011/02/ACTA-Comment-Thirty-ProfessorsUSTR-2010-0014.pdf>; Jack Goldsmith \& Lawrence Lessig, "Anti-Counterfeiting Agreement Raises Constitutional Concerns,” Op-Ed, The Washington Post (26 March 2010), online: Washington Post <http://www.washingtonpost.com/wp-dyn/content/article/2010/03/25/AR2010032502403.html>. European Parliament, Motion for a Resolution pursuant to Rule 90(6) of the Rules of Procedure on the Compatibility of the Anti-Counterfeiting Trade Agreement (ACTA) with the Treaties, B7-0283/2011 (4 May 2011), online: European Parliament < http://www.europarl.europa.eu/sides/getDoc.do?pubRef=//EP//NONSGML+MOTION+B7-2011-0283+0+DOC+PDF+V0//EN>. See also, "Opinion of European Academics," supra note 47 at 2-4 (stating that "certain ACTA provisions are not entirely compatible with EU law and will directly or indirectly require additional action on the EU level” (ibid at 2)).

House of Commons, Standing Committee on Canadian Heritage, The Canada-European Union Comprehensive Economic and Trade Agreement, The Anti-Counterfeiting Trade Agreement and Issues Regarding Cultural Diversity (March 2011), (Chair Michael Chong) at 11-12, online: Government of Canada <http://publications.gc.ca/collections/collection_2011/parl/XC61-403-1-1-04-eng.pdf > [Report of the Standing Committee on Canadian Heritage]. WIPO Copyright Treaty, 20 December 1996, 36 ILM 65, online: WIPO <http://www.wipo.int/treaties/ en/ip/wct/trtdocs_wo033.html> [WCT].

WIPO Performances and Phonograms Treaty, 20 December 1996, 36 ILM 76, online: WIPO $<$ http://www.wipo.int/treaties/en/ip/wppt/trtdocs_wo034.html> [WPPT]. Canada is already compliant with most provisions of WIPO Internet Treaties, by virtue of having implemented TRIPS, supra note 3 and the Berne Convention, supra note 23. However, WIPO Internet Treaties imposed new obligations, such as protections for TPMs and RMI, which required implementing legislation. wct_wppt/wct_wppt.html> [WIPO Internet Treaties]. 
Nevertheless, a number of factors support ACTA coming into force. Only six signatories must ratify the agreement for it to come into force, which in part reflects the relatively small number of negotiating countries, comprising only a subset of the total WTO membership. ${ }^{69}$ In the US, giving force to ACTA is an explicit objective in President Obama's 2011 trade agenda. ${ }^{70}$ At the same time, the USTR, which is the agency within the US executive branch with responsibility for trade and which negotiates with foreign governments to create trade agreements, takes the expeditious position that ACTA need not be approved by Congress since it is a "sole executive agreement" (as opposed to a treaty which would require Senate approval), and that US law is already compliant with its provisions. ${ }^{71}$ On the European side, the European Parliament has approved a free trade agreement with South Korea with intellectual property law provisions similar to ACTA's provisions. ${ }^{72}$ Given this, it would appear unlikely that the European Parliament would endorse an argument that ACTA goes beyond the intellectual property law of the EU. In fact, a resolution of the European Parliament, issued when ACTA's final text was going through legal review, described the treaty as "a step in the right direction" and stated that ACTA will not change EU intellectual property law. ${ }^{73}$ However, more recently, in its July 2011 assessment of ACTA, the European Parliament's Directorate-General for External Policies was much more qualified, with a primary recommendation that "unconditional consent would be an inappropriate response from the European Parliament given the issues that have been identified with ACTA [as] it stands." 74 This cautious stance is reflected in the lack of any EU representation in the composition of the initial signatory countries to ACTA. In Canada, the first steps toward

\section{$69 \quad$ ACTA, supra note 2, art 40.1.}

70 USTR, “The President's 2011 Trade Policy Agenda” (2011) at 11, online: USTR <http://www.ustr.gov/ webfm_send/2587>; see also Executive Office of the President of the United States, "Administration's White Paper on Intellectual Property Enforcement Legislative Recommendations” (March 2011), online: Executive Office of the President of the United States <http://www.whitehouse.gov/sites/default/ files/ip_white_paper.pdf $>$ (identifying specific recommended legislative changes to increase the effectiveness of US efforts to enforce intellectual property rights, including increasing the statutory maximum for certain offenses, increasing the sentencing guideline range for intellectual property offenses, amending legislation to provide more tools to enforcement agencies to combat infringement, amending legislation to allow the Department of Homeland Security to share information about enforcement activities with right holders, amending legislation to improve enforcement efforts involving pharmaceuticals including counterfeit drugs, amending Customs and Border Protection (CBP) administrative penalties to increase CBP's authority, and amending legislation to provide a right of public performance to improve international enforcement efforts).

71 United States Senate, Committee on Finance-Hearing on the 2011 Trade Agenda (9 March 2011), online: Knowledge Ecology International <http://keionline.org/sites/default/files/RonKirk_SFC_9Mar 2011.pdf > at 27-28. See also Sean Flynn, "ACTA's Constitutional Problem: The Treaty is Not a Treaty" (2011) 26:3 Am U Int'l L Rev 903 (arguing that ACTA could pose a unique US constitutional problem, which would arise if the President approved the agreement as a sole executive agreement without seeking Congressional consent; in that event, ACTA could be a binding treaty under international law and yet not be a treaty under US constitutional law because the President lacks constitutional authority to bind the US to the agreement without congressional consent).

72 See Monika Ermert, “Stronger IP Rights In EU-Korea FTA: Precedent For Future FTAs?” (20 February 2011), online: Intellectual Property Watch <http://www.ip-watch.org/weblog/2011/02/20/stronger-iprights-granted-in-eu-korea-fta-precedent-for-future-ftas/>; Letter from intellectual property lobby groups to Jerzy Buzek, President of the European Parliament (20 April 2011), online: Scribd <http://www. scribd.com/doc/54799890/ACTA-Lobby-Letter>.

73 European Parliament, "European Parliament resolution of 24 November 2010 on the Anti-Counterfeiting Trade Agreement (ACTA),” B7 0618/2010, (24 November 2010), online: European Parliament <http:// www.europarl.europa.eu/sides/getDoc.do?pubRef=-//EP//TEXT+TA+P7-TA-2010-0432+0+DOC+ $\mathrm{XML}+\mathrm{V0} / / \mathrm{EN}>$. See also EC, Commission Services Working Paper, "Comments on the 'Opinion of European Academics on Anti-Counterfeiting Trade Agreement”" (27 April 2011) at 1, online: EC <http://trade.ec.europa.eu/doclib/docs/2011/april/tradoc_147853.pdf> (stating “After close examination of the Opinion, we believe that the opinion fails to demonstrate, in a convincing manner, that ACTA is not in line with the relevant Community acquis or that it raises legitimate concerns as regards certain fundamental rights”) [Commission Services Working Paper]. ACTA Assessment, supra note 15 at 66. 
ACTA ratification have begun with Bill C-11, the Copyright Modernization Act, which addresses some of the agreement's digital copyright measures. ${ }^{75}$ However, ACTA ratification will require further legislative changes, in particular to enhance the powers of custom and border authorities to enforce intellectual property rights.

\section{ACTA's CONTENT AND RIgHTS HOLDER ORIENTATION}

Over the course of the negotiations, many of the most controversial provisions in ACTA were either deleted or narrowed in scope. Yet the agreement retains its focus as a rightsholder oriented agreement that strengthens the enforcement and protection of intellectual property rights. As such, the criticism that the agreement does not always sufficiently attend to other rights and interests still has resonance. Further, many of the provisions that originally attracted concern are still in the agreement, albeit couched as non-binding provisions. Although these provisions are permissive, they nonetheless enjoy the soft power of being incorporated in the agreement.

ACTA's claimed purpose is that it is an agreement to combat copyright piracy and trademark counterfeiting. However, many perceive ACTA to be representative of a larger movement endemic to international agreements on intellectual property, whereby the agreement is one step in an overall progression toward stronger control by rights holders. In the wake of TRIPS, developing countries and public domain advocates have argued that industrial countries aim to achieve a goal of ratcheting up international intellectual property protection and enforcement, while simultaneously deflecting changes that would support greater user access and the interests of developing countries. ${ }^{76} \mathrm{~A}$ number of indicators support the characterization of ACTA as embracing a protectionist agenda for more rigorous control of intellectual property by rights holders: ACTA's TRIPS-plus model; the regime shift to a new forum; the discourse to promote ACTA; the choice of a minimum-standards agreement; and the recognition of new rights without a perfect corollary of defences, exceptions, and recognition of other interests.

\section{A. ACTA's TRIPS-PLUS MODEL}

Foremost, ACTA's level of intellectual property protection and enforcement exceeds that of TRIPS. That is, ACTA is a TRIPS-plus agreement, defined as a model that "requires a Member to implement a more extensive standard; or which eliminates an option for a Member under a TRIPS standard." "77 TRIPS-plus protection is permitted by TRIPS, which provides that members may implement more extensive protection than TRIPS requires, as long as that protection does not contravene the provisions in TRIPS. ${ }^{78}$ TRIPS exists as an

$75 \quad$ Bill C-11, supra note 37.

See e.g. Peter M Gerhart, "Why Lawmaking for Global Intellectual Property is Unbalanced” (2000) 22 EIPR 309 at 309 (arguing that the international mechanism of intellectual property norm-setting "is not designed to give us a global system that comes anywhere near a socially optimum system”).

See Peter Drahos, "BITs and BIPs: Bilateralism in Intellectual Property” (2001) 4:6 J World Intell Prop L 791 at 793 [Drahos, "BITs and BIPs”]. "The term 'TRIPS-plus' is used to cover two different types of consequences in this article. TRIPS confers on its Members the discretion to implement 'more extensive protection' than is conferred by TRIPS standards (see Article 1.1). TRIPS also allows members to qualify the operation of some standards, to choose amongst standards or to choose when to adopt standards ('option-creating standards')” (ibid at 792). 
international intellectual property agreement establishing a global "one-size-fits all”79 mode of protection ${ }^{80}$ to which all WTO members are subject. TRIPS already establishes minimum standards for the protection of intellectual property rights, sets out rules for the enforcement of intellectual property rights, and makes available the WTO's dispute resolution mechanism for intellectual property disputes between member countries. ${ }^{81}$ TRIPS addresses the enforcement of intellectual property rights in Part III of the agreement, with a general obligation that its specified enforcement procedures be available under a member's law "so as to permit effective action against any act of infringement of intellectual property rights covered by this Agreement, including expeditious remedies to prevent infringements and remedies which constitute a deterrent to further infringements," but "shall be applied in such a manner as to avoid the creation of barriers to legitimate trade and to provide for safeguards against their abuse." 82 Thus ACTA exists as an overlay to the enforcement provisions already established in TRIPS.

Moreover, ACTA was negotiated in the aftermath of regional and bilateral trade agreements that have spread the TRIPS-plus model of protection and enforcement. The US and EU came to the ACTA negotiations after they respectively had already achieved a TRIPSplus model of intellectual property protection and enforceability in a bundle of bilateral and

Peter K Yu, “The International Enclosure Movement” (2007) 82:4 Ind LJ 827 at 832 [Yu, “ International Enclosure Movement”]; Peter K Yu, “The Objectives and Principles of the TRIPS Agreement” (2009) 46:4 Hous L Rev 979 at 981 [Yu, “Objectives and Principles of TRIPS”]; James Boyle, “A Manifesto on WIPO and the Future of Intellectual Property" (2004) 9 Duke L \& Tech Rev 1 at 3-4. This one-sizefits-all result was earlier warned against by Paul A David, "Intellectual Property Institutions and the Panda's Thumb: Patents, Copyrights, and Trade Secrets in Economic Theory and History” in Mitchel B Wallerstein, Mary Ellen Mogee \& Roberta A Schoen, eds, Global Dimensions of Intellectual Property Rights in Science and Technology (Washington, DC: National Academy Press, 1993) 19 at 54-55 (showing pessimism with respect to the practicality of establishing a uniform international intellectual property system and predicting that the efforts to establish such a system may result in an intellectual property regime suitable to serve the interests and policies of one or a group of countries that are to be enforced on countries that do not have similar interests or policies).

$80 \quad$ See Understanding on Rules and Procedures Governing the Settlement of Disputes, Annex 2 of the Marrakesh Agreement, Establishing the World Trade Organization, 15 April 1994, 33 ILM 1125 [DSU]. The DSU has been described as the "teeth" that have overcome the enforceability difficulties that the Berne Convention suffered from; see Laurence R Helfer, "Toward a Human Rights Framework for Intellectual Property” (2007) 40:3 UC Davis L Rev 971 at 984-85; Daniel J Gervais, The TRIPS Agreement: Drafting History and Analysis, 2nd ed (London: Sweet \& Maxwell, 2003) at 124.

TRIPS, supra note 3, Part III: Enforcement of Intellectual Property Rights; DSU, ibid. See Rochelle Cooper Dreyfuss, “TRIPS-Round II: Should Users Strike Back?” (2004) 71:1 U Chicago L Rev 21 at 21 (arguing that the TRIPS Agreement is mainly designed to serve the interests of rights holders with little attention to the interests of users) [Dreyfuss, “TRIPS-Round II”]; Graeme B Dinwoodie \& Rochelle Cooper Dreyfuss, "International Intellectual Property Law and the Public Domain of Science” (2004) 7:2 J Int'l Econ L 431 at 448 (stating “[t]o put it another way, because the TRIPS Agreement was negotiated with the goal of promoting international trade, the goals of substantive balance common to domestic intellectual property systems are barely discernible in its provisions”) [Dinwoodie \& Dreyfuss, "International Intellectual Property Law”]; Frederick M Abbott, “The Enduring Enigma of TRIPS: A Challenge for the World Economic System” (1998) 1:4 J Int’l Econ L 497 at 499 (arguing that TRIPS is a global intellectual property regime that meets the interests of intellectual property industries in the developed world) [Abbott, "Enduring Enigma of TRIPS"]. Even prior to introducing the TRIPS Agreement, industrial countries had sought to revise international intellectual property conventions in order to expand the level and scope of intellectual property protection and enforceability as, for example, with the Berne Convention, supra note 23. See Peter Burger, "The Berne Convention: Its History and Its Key Role in the Future” (1988) 3 JL \& Tech 1 at 7; Ruth Okediji, "Toward an International Fair Use Doctrine” (2000) 39:1 Colum J Transnat'l L 75 at 104-105, stating:

The minimalist nature of the [Berne Convention] obfuscated the real, if yet unrealized, triumph for high-protectionist states, namely that international copyright could only get stronger. Highprotectionist countries, such as France, incurred short-term costs in not obtaining higher levels of protection at the Conventions' inception but, for the long term, the fact that there was an international agreement that, by its terms, contemplated future revisions to improve the system and make the rights more secure, was by far the most vital victory. 
regional trade agreements with other, largely developing, nations. ${ }^{83}$ Although early drafts of ACTA suggested it would take the form of a more extreme "TRIPS-plus-plus" model that would usher in a new stage for international intellectual property, ${ }^{84}$ the final version is more accurately described as another TRIPS-plus agreement. With the shifting of ACTA's more controversial provisions to permissive obligations, ACTA's softened final version is often weaker and less comprehensive than these existing regional and bilateral free trade agreements. $^{85}$ The July 2011 ACTA study sponsored by the European Parliament even suggests that ACTA's norms will be influential globally precisely because they are weaker than those that the US and EU were able to secure in regional and bilateral free trade agreements, giving new partners an incentive to push for ACTA's standards as an "alternative and less stringent” starting point than the standards in existing trade agreements. ${ }^{86}$

\section{B. ACTA's REGIME SHIFT}

ACTA's regime shift is also indicative of the agreement's rights-holder orientation. As noted, ACTA's move toward an independent governing body and away from both WIPO and the WTO is an example of the kind of regime-shifting that had earlier caused developed countries, with the vocal urging of major industries, to move international intellectual property norm-setting from WIPO to the WTO (with TRIPS), ${ }^{87}$ and then to rely on a net of bilateral and regional trade agreements to establish tougher intellectual property protection standards than TRIPS. With ACTA, the international intellectual property regime has shifted

83 See e.g. Agreement between the United States of America and the Hashemite Kingdome of Jordan on the Establishment of a Free Trade Area, (US and Jordan) 24 October 2000, 41 ILM 63; United StatesChile Free Trade Agreement, (US and Chile) 6 June 2003, 42 ILM 1026 (entered into force 1 January 2004); United States-Singapore Free Trade Agreement, (US and Singapore) 6 May 2003, 42 ILM 1026 (entered into force 1 January 2004); United States-Morocco Free Trade Agreement, (US and Morocco) 15 June 2004, 44 ILM 544 (entered into force 1 January 2006); Euro-Mediterranean Agreement establishing an Association between the European Communities and their Member States, of the one part, and the Hashemite Kingdom of Jordan, of the other part, 2002/357/EC, 45 OJL 129. For a comprehensive discussion of the role of bilateralism in the international intellectual property regime, see Drahos, "BITs and BIPs," supra note 77 at 803 (discussing bilateralism as a major mechanism that the US and the EU are utilizing to oblige developing countries to adhere to levels of intellectual property higher than the standards required by multilateral instruments of intellectual property protection and warning developing countries that they are being led "into a highly complex multilateral/bilateral web of intellectual property standards that are progressively eroding not just their ability to set domestic standards, but also their ability to interpret their application through domestic administrative and judicial mechanisms”); Ruth L Okediji, "Back to Bilateralism? Pendulum Swings in International Intellectual Property Protection” (2003-2004) U Ottawa L Tech J 125 [Okediji, “Back to Bilateralism”] (arguing that bilateralism has always been a mechanism used in regulating international relations; however, while the old bilateralism tended to confer mutual benefits on both contracting members, the new bilateralism that the US is adopting now in its foreign trade relations resembles a regime-shifting tactic that aims at developing an expansive intellectual property protection model free of the limitations required by the TRIPS Agreement).

84 See Susan K Sell, "The Global IP Upward Ratchet, Anti-Counterfeiting and Piracy Enforcement Efforts: The State of Play" (9 June 2008), online: IQsensato <http://www.iqsensato.org/pdf/Sell_IP_ Enforcement_State_of_Play-OPs_1_June_2008.pdf $>$ [Sell, “Global IP”].

85 ACTA Assessment, supra note 15 at 16: "ACTA standards are generally not as strong or as extensive as the standards that both the US and the EU have been pushing in their bilateral FTAs”; Kimberlee Weatherall, “ACTA as a New Kind of International IP Lawmaking,” (2011) 26:3 Am U Int’l L Rev 839 at $874-75$.

86 ACTA Assessment, ibid at 16.

87 See Helfer, "Regime Shifting," supra note 18 at 19; Susan K Sell, Private Power, Public Law: The Globalization of Intellectual Property Rights (Cambridge, UK: Cambridge University Press, 2003) at 96-120 (discussing the consensus amongst major industries in Japan, US, and the EU on seeking IP multilateral agreements and their input in the TRIPS negotiations). 
again to a plurilateral "club," ${ }^{\text {„8 }}$ whereby only a select few from WTO’s multilateral diverse membership are invited. This has led some commentators to conclude that ACTA's negotiations deliberately eschewed the multilateral regimes' intellectual property normsetting in order to escape global accountability. ${ }^{89}$ By avoiding WIPO and the WTO as norm-setting forums, the ACTA negotiations denuded the role of developing countries, which have recently started to take a more active role in these organizations' governance and norm production. $^{90}$

One example of developing countries' recent success at reforming the international intellectual property regime in forums outside of ACTA materialized in the adoption of the WIPO Development Agenda. ${ }^{91}$ The WIPO Development Agenda has 45 recommendations categorized under six clusters (A-F). ${ }^{92}$ Under these clusters some recommendations pointedly recognize the danger of excessive levels of intellectual property protection. For example, Cluster A, Recommendation 10 calls for "making national intellectual property institutions more efficient and promot[ing] fair balance between intellectual property protection and the public interest." 93 Cluster B, Recommendation 15 calls for WIPO's norm-setting to take into consideration "different levels of development" and "a balance between costs and benefits."94 Further, Cluster B, Recommendation 16 calls for "the preservation of the public domain within WIPO's normative processes" and to "deepen the analysis of the implications and benefits of a rich and accessible public domain." 95 Cluster C, Recommendation 25 calls for "promot[ing] the transfer and dissemination of technology, to the benefit of developing countries and to take appropriate measures to enable developing countries to fully understand and benefit from different provisions, pertaining to flexibilities provided for in international agreements, as appropriate." ${ }^{\text {"6 }}$ Perhaps most salient to the policy issues raised by ACTA, Cluster F, Recommendation 45 calls for the "societal interests" and the "developmentoriented concerns" of developing countries to be taken into consideration when approaching intellectual property rights enforcement. The same recommendation emphasizes that " "the protection and enforcement of intellectual property rights should contribute to the promotion of technological innovation and to the transfer and dissemination of technology, to the

Daniel Gervais, "China - Measures Affecting the Protection and Enforcement of Intellectual Property Rights” (2009) 103:3 AJIL 549 at 555 (stating that ACTA's approach to international intellectual property norm-setting “is a 'club approach' in which like-minded jurisdictions define enforcement 'membership' rules and then invite other countries to join, presumably via other trade agreements”). "See “The Proposed Anti-Counterfeiting Trade Agreement (ACTA): Global Policy Implications” (2 June 2008) 2:8 In Focus 1 at 7, online: IQsensato <http://www.iqsensato.org/pdf/InFocus\%20-ACTA \%20-\%20Vol\%202\%20-Issue\%208.pdf> [Proposed ACTA: “Global Policy Implications”].

See Sell, "Global IP,” supra note 84; Kaminski, supra note 47 at 247 (describing the shift of norm setting from WIPO and the WTO as "a form of international bullying"); Gross, "On the Proposed ACTA,” supra note 21 at 5-6; Michael Geist, “Canada’s ACTA Briefing, Part One: ACTA is a Response to WIPO Gridlock” (6 April 2009), online: Michael Geist <http://www.michaelgeist.ca/content/view/ $3830 / 125 />$

91 WIPO, Assemblies of the Member States of WIPO, General Report, A/43/16, 43rd Series of Meetings (Geneva, 24 September to 3 October 2007), online: WIPO <http://www.wipo.int/edocs/mdocs/gov body/en/a_43/a_43_16-main1.pdf> [WIPO Development Agenda].

92 Cluster A: Technical Assistance and Capacity Building; Cluster B: Norm-setting, flexibilities, public policy and public domain; Cluster C: Technology Transfer, Information and Communication Technologies (ICT) and Access to Knowledge; Cluster D: Assessment, Evaluation and Impact Studies; Cluster E: Institutional Matters including Mandate and Governance; and Cluster F: Other Issues: WIPO, "The 45 Adopted Recommendations under the WIPO Development Agenda," online WIPO <http:// www.wipo.int/ip-development/en/agenda/recommendations.html>.

Ibid, Recommendation 10.

Ibid, Recommendation 15.

Ibid, Recommendation 16.

Ibid, Recommendation 25. 
mutual advantage of producers and users of technological knowledge and in a manner conducive to social and economic welfare, and to a balance of rights and obligations', in accordance with Article 7 of the TRIPS Agreement." 97

Developing countries have advocated using the WIPO Development Agenda as a measure to achieve a fairer international intellectual property regime that recognizes the interests of both net exporters and net importers of intellectual property. ${ }^{98}$ However, the recent history of international intellectual property law-making — in particular the regime shifts first away from WIPO toward the WTO TRIPS Agreement and now toward ACTA, the TRIPS-plus level of protection in post-TRIPS regional and bilateral agreements, the TRIPS-plus level of protection through enhanced enforcement in ACTA, and the exclusion of most developing countries from the ACTA negotiations - suggests industrial countries are less than eager to endorse initiatives to reform the international intellectual property regime in light of a development purpose. ${ }^{99}$

While some developing countries were invited to the ACTA negotiations, the major developing countries that have been actively negotiating to reshape international intellectual property norms and advocating for a balanced international intellectual property regime were not invited, including China, India, and Brazil. ${ }^{100}$ Even when the idea of ACTA was raised at the G8 summits, Russia was left out of the discussions since it does not share the same perspective as other G8 countries on the enforcement of intellectual property. ${ }^{101}$ For an agreement that aspires to strengthen intellectual property rights enforcement, it is interesting that the main sources of origin for "counterfeit trademark goods" and "pirated copyright goods” are not among ACTA’s participants.

The decision of the founders of ACTA to invite certain developing countries and to exclude others leads to three observations. First, these developed countries sought an agreement that reflects their interests as net exporters of intellectual property subject matter. Second, at that stage, the developed countries were not concerned about the number of countries joining the negotiations because, as in the case of TRIPS, they thought they

$97 \quad$ Ibid, Recommendation 45.

98 See Peter K Yu, “A Tale of Two Development Agendas” (2009) 35:2 Ohio NUL Rev 465 (arguing that the efforts taken by less-developed countries through advancing development agendas at WIPO, the WTO, and other international fora to develop an innovation and intellectual property regime considerate of their development needs are "remarkably similar" in motives and goals to their efforts taken between the period of 1960-1970) (ibid at 467).

99 An earlier example is when the Stockholm Protocol that developing countries introduced failed after developed countries refrained from ratifying it. The Stockholm Protocol Regarding Developing Countries, 14 July 1967, 828 UNTS 281 [Stockholm Protocol]. See Valerio De Sanctis, "The International Copyright Conventions” (1978) 14 Copyright 254 at 258; Burger, supra note 81 at 20. On ACTA and the WIPO Development Agenda, see e.g. Michael Geist, "The ACTA Threat to the Future of WIPO” (14 April 2009), online: IP Watch < http://www.ip-watch.org/weblog/2009/04/14/the-acta-threatto-the-future-of-wipo/> (arguing that ACTA poses a serious danger to the success of the WIPO Development Agenda).

100 See Gross, “On the Proposed ACTA,” supra note 21 at 2; Kaminski, supra note 47 at 254-55. Michael Geist reported that Brazil expressed its wish to join ACTA's negotiations to one of the negotiating countries, but the Brazilian request had not received an answer. Michael Geist, "ACTA Update: New Meetings, New Partners, New Issues” (30 June 2009), online: Michael Geist <http://www.michael geist.ca/content/view/4092/408>.See also Monika Ermert, "Indian Official: ACTA Out of Sync with TRIPS and Public Health” (5 May 2010), online: IP Watch <http://www.ip-watch.org/weblog/2010/ 05/05/indian-official-acta-out-of-sync-with-trips-and-public-health>, which reported that Ashutosh Jindal, advisor at the Embassy of India to the EU, stated that India had not been invited to ACTA's negotiations.

101 See Yu, "Six Secret Fears," supra note 38 at 982. 
practically had enough mechanisms to impose ACTA's norms on developing countries, regardless of whether or not the latter participated in the ACTA negotiations or agreed with the outcome. ${ }^{102}$ As suggested by the ACTA Preamble's reference to the "world economy" and the importance of effective intellectual property rights enforcement to sustain economic growth "globally," 103 the participating countries expect that over time ACTA's norms are likely to be influential for subsequent regional and bilateral agreements, later multilateral discussions, and as a source of norms for international dispute resolution. Third, by inviting specific developing countries to the negotiations, the founding developed countries could destigmatize the agreement as one that was negotiated merely amongst developed nations and could assign participating developing countries the role of promoting the agreement in their regions. ${ }^{104}$

\section{ACTA'S DISCOURSE}

The discourse to promote ACTA has also been framed in support of rights holders' interests. ${ }^{105}$ In their launch of the ACTA negotiations, the participating developed countries argued that counterfeit and pirated goods in international trade had been causing intellectual property rights holders economic losses, hindering the sustainable development of both developed and developing countries, and risking consumers' safety; therefore, they posited, the solution was a new agreement embodying international cooperation toward stronger intellectual property rights enforcement. ${ }^{106}$ This argument shares many similarities with the reasoning that the US and other developed countries publicized to introduce the TRIPS Agreement. ${ }^{107}$ However, the developed countries in the ACTA negotiations placed more emphasis on the security and safety aspects of the enforcement issue. ${ }^{108}$ Such a framing tactic was aimed at generating public support for stronger enforcement of intellectual property rights and at involving a network of actors, both national and international and both private

See Kaminski, supra note 47 at 250; Gross, “On the Proposed ACTA,” supra note 21 at 4-5 (arguing that ACTA is an "undemocratic" and "imperialistic" treaty since ACTA will ultimately be imposed on countries that have not participated in the negotiations of its provisions, mainly developing countries); see also Peter K Yu, “TRIPS and its Discontents” (2006) 10 Marq Intell Prop L Rev 369 (providing four different narratives of the origins of the TRIPS Agreement: the bargain narrative, the coercion narrative, the ignorance narrative, and the self-interest narrative); Peter Drahos, "Global Property Rights in Information: The Story of TRIPS at the GATT" (1995) 13:1 Prometheus 6 at 16 (arguing that "[t]he intellectual property story [including its TRIPS segment] is one of coercion, but it is economic rather than military in kind").

ACTA, supra note 2, Preamble, paras 2, 1.

After the US signed its Free Trade Agreement with Jordan, the US presented Jordan to the Arabic World as a role model that should be followed. See Embassy of the United States in Abu Dhabi, UAE, Press Release, "U.S.-UAE Free Trade Agreement Press Conference" (8 March 2005), online: Embassy of the United States in Abu Dhabi <http://web.archive.org/web/20100527110336/http://abudhabi.usembassy. gov/pr_10mar2005.html>; "US Negotiators Open Free Trade Talks With UAE," Dow Jones International News (8 March 2005).

Peter Drahos defines "framing" as "a form of public dialogue in which actors wishing to change political processes offer an alternative conceptual scheme through which to reinterpret those processes." Peter Drahos, "Does Dialogue Make a Difference? Structural Change and the Limits of Framing" (2008) 117 Yale LJ (Pocket Part) 268. See USTR, "Summary of Key Elements," supra note 39.

See Amy Kapczynski, "The Access to Knowledge Mobilization and the New Politics of Intellectual Property" (2008) 117:4 Yale LJ 804 at 848 (describing the "public interest" frame in which the American industry lobby presented the issue of intellectual property protection in order to show the need for the TRIPS Agreement). 
and public, to achieve this goal. ${ }^{109}$ An example of this network-based partnership toward stronger intellectual property rights enforcement is embodied in the Global Congress on Combating Counterfeiting and Piracy, which was launched in 2004 to address the problem of trade in counterfeit and pirated goods as a health hazard and a source of funding for organized crime. ${ }^{110}$ This conference initiated the very early thoughts of ACTA and continues to support it.

\section{ACTA AS A Minimum STANDARDS AgREEMENT}

Another aspect supporting rights holders' interests, and which will likely contribute to a general ratcheting up of international intellectual property norms, is that ACTA sets out only minimal levels of protection and enforcement, and thus countries are free to adopt stronger measures of enforcement. ${ }^{111}$ Similarly, TRIPS is a minimum standards agreement since it permits more extensive protection as long as the protection does not contravene its provisions. ${ }^{112}$ However, whereas TRIPS permits member countries to implement more extensive protection for intellectual property, ACTA permits its parties to implement more extensive enforcement of intellectual property rights. ${ }^{113}$ Both agreements include the proviso that such increased scope in protection (in the case of TRIPS) or in enforcement (in the case of ACTA) must not contravene the respective agreement. ${ }^{114}$ Both agreements also provide that countries "shall be free to determine the appropriate method of implementing the provisions" in their "own legal system and practice." intellectual property rights reflects an infrastructural bias in the international intellectual property regime generally, and in ACTA specifically, toward rights holders and at the expense of users of intellectual property. ${ }^{116}$

All ACTA parties are also members of the WTO and therefore must comply with TRIPS. ACTA's Preamble asserts that the parties intend to "provide effective and appropriate means, complementing the TRIPS Agreement, for the enforcement of intellectual property rights,

Ibid; Proposed ACTA: "Global Policy Implications," supra note 89 at 6; Peter Drahos, "Securing the Future of Intellectual Property: Intellectual Property Owners and Their Nodally Coordinated Enforcement Pyramid” (2004) 36 Case W Res J Int'l L 53 at 54 (arguing that “nodal coordination of an international enforcement pyramid offers non-state actors the possibility of securing compliance by states with emerging global standards of intellectual property rights"). See "Global Congress on Combating Counterfeiting and Piracy," online: Global Congress <http://www. ccapcongress.net/index.htm>.

ACTA, supra note 2, art 2.1.

TRIPS, supra note 3, art 1.1.

Ibid. Article 1.1 provides:

Members shall give effect to the provisions of this Agreement. Members may, but shall not be obliged to, implement in their law more extensive protection than is required by this Agreement, provided that such protection does not contravene the provisions of this Agreement. Members shall be free to determine the appropriate method of implementing the provisions of this Agreement within their own legal system and practice.

ACTA, supra note 2, art 2.1 provides:

Each Party shall give effect to the provisions of this Agreement. A Party may implement in its law more extensive enforcement of intellectual property rights than is required by this Agreement, provided that such enforcement does not contravene the provisions of this Agreement. Each Party shall be free to determine the appropriate method of implementing the provisions of this Agreement within its own legal system and practice. ACTA, ibid, art 2.1; TRIPS, ibid, art 1.1.

ACTA, ibid; TRIPS, ibid.

See Drahos, "BITs and BIPs," supra note 77 at 798 (stating that integrating a "minimum standard" mode of protection in international intellectual property agreements is an element in the efforts toward ratcheting up the protection and enforceability of intellectual property). 
taking into account differences in their respective legal systems and practices.”117 This suggests that ACTA is intended to serve as an overlay to fill in gaps or uncertainties in TRIPS about intellectual property rights enforcement; however, because ACTA parties must also comply with TRIPS, it is just as important that TRIPS fill in any gaps and uncertainties in ACTA's text, especially TRIPS's limitations on rights holders and user safeguards. ACTA's text provides scant interpretive guidance about how the two agreements relate to one another, especially the interplay between ACTA and TRIPS Part III on enforcement, and how parties should implement ACTA in a TRIPS-compliant manner.

Article 1 of ACTA explicitly references TRIPS in noting that “[n]othing in this Agreement shall derogate from any obligation of a Party with respect to any other Party under existing agreements, including the TRIPS Agreement." ${ }^{118}$ ACTA also explicitly adopts the principles referenced in Articles 7 and 8 of the TRIPS Agreement. ${ }^{119}$ Article 7 of TRIPS specifically refers to a "balance of rights and obligations" in the protection and enforcement of intellectual property rights, whereas Article 8 permits member states to adopt measures necessary to protect public health and nutrition and prevent restraint of trade "provided that such measures are consistent with the provisions of this Agreement." ${ }^{\prime 20}$ These articles in TRIPS, which are cross-referenced in ACTA, incorporate some flexibilities within TRIPS's overall one-size-fits-all regime and were intended to reflect developing countries' concerns. ${ }^{121}$ Additionally, ACTA's Preamble makes reference to non-rights holders' interests, with the parties' recognition that "measures and procedures to enforce intellectual property rights" should "not themselves become barriers to legitimate trade"122 and that measures to address intellectual property rights infringements in the digital environment should be done in a "manner that balances the rights and interests of the relevant right holders, service providers, and users.”123

Even though ACTA nominally endorses the TRIPS flexibilities and pays heed in the Preamble to balancing and to users' interests, concerns still circulate about ACTA's negative implications for access to information. First, the TRIPS flexibilities have been interpreted narrowly by WTO panels. ${ }^{124}$ Second, although ACTA members must comply with any

ACTA, supra note 2, Preamble, para 4 [emphasis added].

Ibid, art 1.

Ibid, art 2.3.

TRIPS, supra note 3. Article 7 provides: "The protection and enforcement of intellectual property rights should contribute to the promotion of technological innovation and to the transfer and dissemination of technology, to the mutual advantage of producers and users of technological knowledge and in a manner conducive to social and economic welfare, and to a balance of rights and obligations." Article 8.1 of TRIPS, provides: "Members may, in formulating or amending their laws and regulations, adopt measures necessary to protect public health and nutrition, and to promote the public interest in sectors of vital importance to their socio-economic and technological development, provided that such measures are consistent with the provisions of this Agreement." Article 8.2 provides: "Appropriate measures, provided that they are consistent with the provisions of this Agreement, may be needed to prevent the abuse of intellectual property rights by right holders or the resort to practices which unreasonably restrain trade or adversely affect the international transfer of technology." See also Yu, "Objectives and Principles of TRIPS," supra note 79.

121 Carlos M Correa, Trade Related Aspects of Intellectual Property Rights: A Commentary on the TRIPS Agreement (New York: Oxford University Press, 2007) at 91-92 [Correa, Trade Related Aspects of Intellectual Property Rights]. ACTA, supra note 2, Preamble, para 5.

Ibid, Preamble, para 6.

See e.g. WTO, Canada - Patent Protection of Pharmaceutical Products: Complaint by the European Communities and their member States, WT/DS114/R (17 March 2000), online: WTO <http://www.wto. org/english/tratop_e/dispu_e/7428d.pdf> (ruling, against Canada, that the stockpiling exception in section 55.2(2) of the Patent Act, RSC 1985, c P-4, was inconsistent with TRIPS). The WTO Panel wrote 
mandatory obligations under TRIPS, ${ }^{125}$ they may derogate from safeguards in TRIPS that are merely permissive. Third, it is feared that, by surpassing the established enforcement mechanisms in TRIPS, ACTA endangers TRIPS's balance of rights and obligations. Both China and India, supported by a number of developing countries, expressed grave concerns to the WTO's Council on TRIPS in June 2010 about ACTA's effect on developing countries, arguing that agreements like ACTA might conflict with TRIPS, threatened to undermine the flexibilities in TRIPS, and could create trade barriers and distort trade. ${ }^{126}$ The European Parliament's July 2011 study of ACTA cautioned that, although ACTA “does not entail such a significant shift in the EU Acquis" and "while it is not fundamentally in conflict with the TRIPS Agreement, it is significantly more stringent and rightholder friendly than the TRIPS Agreement.” ${ }^{127}$ Fourth, ACTA has been criticized for giving insufficient consideration to the considerable resource outlay that such enforcement measures require. TRIPS and ACTA include identical wording that nothing in the agreements "creates any obligation with respect to the distribution of resources as between enforcement of intellectual property rights and enforcement of law in general." ${ }^{\text {"128 }}$ Nonetheless, ACTA compliance, which imposes a burden to dedicate public resources to the enforcement of what are private rights, could have a serious economic impact not only on developing countries but on developed countries - a caution that has previously been expressed about TRIPS-plus bilateralism. ${ }^{129}$

Many of ACTA's obligations may be expected to impose a significant administrative burden and financial cost on member countries, as for example when customs procedures are enhanced to comply with ACTA's requirements for border searches and seizures, and this would limit public resources to fund other projects, such as initiatives to support access to information. ${ }^{130}$ ACTA's Chapter III on Enforcement Practices and Chapter IV on International Cooperation alone entail significant financial and time commitments for ACTA's members. For example, members are required to encourage their competent authorities to develop specialized expertise for enforcing intellectual property rights. ${ }^{131}$ They must "promote the collection and analysis of statistical data" on intellectual property rights infringements and on best practices for preventing and combating infringements, promote "internal coordination" and "joint actions, by its competent authorities responsible for the enforcement of intellectual property rights," and try to promote formal and informal mechanisms for competent authorities to receive rights holders' and other stakeholders' views. ${ }^{132}$ Members must engage in public educational efforts not only to make information available that

that the societal interests that are protected by TRIPS art 8.1 might be protected by measures that are already present in the agreement, such as art 30 (permitting members to provide limited exceptions to patent rights providing certain conditions are met).

ACTA, supra note 2 , art 1 .

WTO, "Council debates anti-counterfeiting talks, patents on life" (8-9 June 2010), online: WTO <http:// www.wto.org/english/news_e/news10_e/trip_08jun10_e.htm>; India intervention on TRIPS-Plus IPR Enforcement, delivered to WTO Council on TRIPS (9 June 2010), online: Knowledge Ecology International <http://keionline.org/node/864>; China Intervention on TRIPS Enforcement Trend (8-9 June 2010), online: Knowledge Ecology International <http://keionline.org/node/883>.

ACTA Assessment, supra note 15 at 6.

ACTA, supra note 2, art 2.2; TRIPS, supra note 3, art 41.5 .

See Okediji, "Back to Bilateralism," supra note 83 at 141 (arguing that bilateralism expanded intellectual property protection and enforceability "at the expense of the public interest both in developed and developing countries").

See McManis, “The Proposed ACTA,” supra note 40 at 1237; Gross, “On the Proposed ACTA,” supra note 21 at 6.

ACTA, supra note 2, art 28.

Ibid, art 28. 
publicizes the legal framework and procedures pertaining to the enforcement of intellectual property rights (presumably aimed at making rights holders more aware of their enforcement options), ${ }^{133}$ but also information that publicizes the "importance of respecting intellectual property rights and the detrimental effects of intellectual property rights infringement" (presumably aimed at deterrence). ${ }^{134}$ Members are also obliged to promote cooperation between countries' competent authorities responsible for enforcing intellectual property rights. ${ }^{135}$ They are required to "endeavour to exchange” information about statistical data, best practices, and legal and regulatory measures. ${ }^{136}$ Additionally, each member "shall endeavour to provide" assistance for capacity building and technical assistance to improve intellectual property rights enforcement. ${ }^{137}$

\section{E. Asymmetry Between Intellectual Property Rights VERSUS DEFENCES, EXCEPTIONS, AND OTHER RIGHTS}

Finally, evidence for ACTA being weighted toward rights holders' interests can be found in the agreement's recognition of new rights, such as the right to protect TPMs and RMI. ${ }^{138}$ Although Article 3.2 of ACTA provides that the agreement does "not create any obligation on a Party to apply measures where a right in intellectual property is not protected under its laws and regulations," 139 presumably that refers to instances where a country has no laws protecting a category of intellectual property rights, such as geographical indications, rather than where the agreement imposes an additional exclusive right for a holder of an intellectual property right, such as copyright, which a member state's law already does protect. Although measures such as the protection of TPMs and RMI arguably constitute an expansion of substantive intellectual property rights if the member country's law did not previously incorporate analogous provisions, these obligations would nevertheless seem to apply to any ACTA member country as long as they have laws protecting copyright, despite the saving clause in Article 3.2. ${ }^{140}$

A related criticism is that $A C T A$ generally imports strong rights-holder provisions without also importing the defences, exceptions, and other laws (for example, privacy and free expression) that leaven those exclusive rights. ${ }^{141}$ As US-based civil society and academic groups remarked while the negotiations were ongoing, ACTA could skew non-US countries' copyright regimes by exporting stringent enforcement provisions from US copyright law that are oriented toward rights holders, while excluding the user protections, such as fair use, free

\footnotetext{
$133 \quad$ Ibid, art 30.

$134 \quad$ Ibid, art 31.

$135 \quad$ Ibid, art 33.

$136 \quad$ Ibid, art 34.

$137 \quad$ Ibid, art 35.

138 Ibid, arts 27.5-27.8.

139 Ibid, art 3.2.
}

140 See e.g. Kimberlee G Weatherall, “ACTA: Australian Section by Section Analysis,” (2010) at 2-3, online: BePress < http://works.bepress.com/kimweatherall/21> [Weatherall, "ACTA: Australian Section by Section Analysis"] (explaining why certain features of Australian law render parts of ACTA "more onerous for Australian businesses, consumers and alleged infringers" (ibid at 2)). member to disclose information if the disclosure would be contrary to its laws, including privacy laws or international agreements to which it is a party, nor to disclose confidential information where the disclosure would impede law enforcement, be contrary to the public interest, or "prejudice the legitimate commercial interests of particular enterprises, public or private.” 
expression, and privacy. ${ }^{142} \mathrm{~A}$ joint opinion of European academics expressed similar reservations during the negotiations about ACTA's relationship with European and international law, opining that "certain ACTA provisions do not ensure a balance between the interests of different parties, since they either eliminate safeguards existing under international law or, after strengthening enforcement measures, fail to introduce corresponding safeguarding measures."

In light of ACTA's rights-holder orientation, Parts IV and V address the procedure and substance of what it specifically means for Canada to adhere to this agreement.

\section{ACTA AND COPYRIGHT REFORM}

In Canada, the ratification of a treaty follows Parliament's passage of any required implementing legislation and Canada's agreement to be bound by the treaty. ${ }^{144}$ Canada signed ACTA on 1 October 2011, but legislative amendments are required before the agreement can be ratified. Canada's most recent copyright amendments in the proposed Copyright Modernization Act, which had its first reading in Parliament a day before the ACTA signing ceremony, was initially drafted to satisfy Canada's obligations under the WIPO Internet Treaties rather than ACTA. However, ACTA was certainly in mind both when Parliament debated the Copyright Modernization Act as Bill C-32 $2^{145}$ in 2010 and when the majority Conservative Government reintroduced it as Bill C-11 in $2011 .{ }^{146}$ The reforms in Bill C-11 address many, though not all, of Canada's obligations under ACTA. Subsequent

Center for Democracy \& Technology, “ACTA Debate Gets Specific,” (18 May 2010), online: CDT $<$ http://www.cdt.org/print/15108>; Program on Information Justice and Intellectual Property (PIJIP), “ACTA Section Analysis,” online: PIJIP IP Enforcement Database <http://sites.google.com/site/iip enforcement/acta-section-analysis>.

143 "Opinion of European Academics," supra note 47 at 5.

144 On the Canadian practice regarding the negotiation and adoption of international treaties, see Daniel Dupras, “International Treaties: Canadian Practice,” PRB 00-04E (3 April 2000), online: Government of Canada, <http://dsp-psd.pwgsc.gc.ca/Collection-R/LoPBdP/BP/prb0004-e.htm\#C.\%C2\%A0Making \%20and\%20Signing\%20a\%20Treaty\%28txt\%29>.

145 Bill C-32, An Act to amend the Copyright Act, 3rd Sess, 40th Parl, 2010, first reading 2 June 2010 [Bill C-32].

146 The Canadian Government referred to ACTA during the 2010 Parliamentary debates on copyright reform and noted that the proposed Copyright Modernization Act (in then Bill C-32, which is identical to Bill C-11 introduced the following year) was compliant with ACTA. See Report of the Standing Committee on Canadian Heritage, supra note 65 at 7 (Minister of International Trade, Peter Van Loan, stating before the Committee, "Bill C-32, as it currently sits, supports the obligations that come under ACTA"). Minister Van Loan observed before the Standing Committee on Canadian Heritage both that Canada's ACTA negotiations were guided by the proposed Copyright Modernization Act (then Bill C-32) and that the progress of that bill would influence the timing of Canada signing ACTA":

We have governed our negotiating position based on Canada's existing law as well as legislation on copyright that is going through the parliamentary process.

We participated in the negotiations [of ACTA]. What was arrived at is an agreement that by and large corresponds with those parameters that will allow for more effective cooperation with other countries in enforcing those intellectual property rights-again, to the benefit of the creators. We are waiting to see what happens to our own legislative processes before we proceed to the final stages of signing, because in order to sign we would obviously have to be comfortable that we can support that treaty with Canadian law.

Report of the Standing Committee on Canadian Heritage, ibid at 6-7 [footnote omitted], citing House of Commons, Standing Committee on Canadian Heritage, Minutes of Proceedings, 40th Parl, 3rd Sess, No 37 (31 January 2011) at 1550 [Minutes of Proceedings]. With respect to ACTA itself, Minister Van Loan stated: "The objective of the countries involved was to create a group that raises the bar for intellectual property rights and for intellectual property rights enforcement in particular. That was the motive behind the anti-counterfeiting agreement, the ACTA. Obviously we support that. We view ourselves as being among those who place a higher value on creators' rights. That was the reason for involvement.” Report of the Standing Committee, ibid at 7, citing Minutes of Proceedings, ibid at 1555. 
legislative changes required to meet the remaining copyright enforcement obligations imposed by ACTA will likely be addressed in an omnibus bill that incorporates all the statutory changes required for Canada to adhere to the agreement, including amendments to other intellectual property statutes.

The Copyright Modernization Act is part of the third phase of Canada's copyright reform process, which is intended to address advancements in technology, especially digital copyright issues, and to satisfy Canada's existing obligations under the WIPO Internet Treaties. Three sets of proposed amendments in 2005, 2008, and 2010 to address these issues all died on the order paper before Bill C-11, which was introduced by the majority Conservative Government in September 2011. ${ }^{147}$ Bill C-11's amendments, which mirror the immediately preceding Bill C-32, are designed to implement the WIPO Internet Treaties and deal with other challenges of digital technologies.

Adherence to ACTA would impose additional legislative obligations that have not been included in the copyright reform efforts to date. The most recently proposed copyright reform statute addresses digital copyright enforcement to comply with existing obligations under the WIPO Internet Treaties and, in so doing, also satisfies ACTA's digital copyright enforcement obligations. However, Canada would still be required to enact legislation to provide border authorities with ex officio powers to seize goods allegedly infringing copyright. Canada may also be required to expand the criminal sanctions for copyright infringement to comply fully with ACTA's obligations to criminalize aiding, enticing, and abetting copyright infringement.

Due care must be taken that any amendments to the Copyright Act to comply with ACTA do not distort important principles of Canadian copyright policy and that they satisfy international human rights principles. Since 2002, the Supreme Court of Canada has "repeatedly held that the overarching purposes of the Copyright Act are twofold: promoting the public interest in the encouragement and dissemination of artistic and intellectual works, and justly rewarding the creator of the work," that is, to balance the interests of rights holders and users. ${ }^{148}$ Equally important, the Supreme Court has held that the fair dealing provisions are user rights, not only exceptions to infringement. ${ }^{149}$ Viewed holistically, the Supreme Court's copyright cases over the last decade remind us that it is as important to recognize that copyright law provides rights for authors and owners as it is to recall that the statute includes user rights, defences, and exceptions to those economic and moral rights that are accorded to owners and authors. The Supreme Court has articulated this principle of copyright balance

See Bill C-60, An Act to Amend the Copyright Act, 1st Sess, 38th Parl, 2005 (first reading 20 June 2005) [Bill C-60]; Bill C-61, An Act to amend the Copyright Act, 2nd Sess, 39th Parl, 2008 (first reading 12 June 2008) [Bill C-61]; Bill C-32, supra note 145; Bill C-11, supra note 37. Bill C-32 died on the order paper when the May 2011 elections were called, which brought in a majority Conservative Government. That government then introduced Bill C-11 in the fall of 2011, which is identical to Bill C-32. Phases One and Two of the copyright reform process addressed previous treaty obligations, including those incurred under TRIPS, and updated the Copyright Act to account for earlier technological advancements that affected copyright, such as providing for copyright protection of computer software. That series of amendments concluded in 1997. part on the cross-appeal)]; See Théberge v Galerie d'Art du Petit Champlain Inc, 2002 SCC 34, [2002] 2 SCR 336 [Théberge]; CCH Canadian Ltd v Law Society of Upper Canada, 2004 SCC 13, [2004] 1 SCR 339 [CCH]; Society of Composers, Authors and Music Publishers of Canada v Canadian Association of Internet Service Providers, 2004 SCC 45, [2004] 2 SCR 427 [SOCAN]. $\mathrm{CCH}$, ibid at para 48. 
in a trilogy of cases: "the purpose of copyright law [is] to balance the public interest in promoting the encouragement and dissemination of works of the arts and intellect and obtaining a just reward for the creator."150 The "proper balance ... lies not only in recognizing the creator's rights but in giving due weight to their limited nature." 151 Integral to the notion of copyright balance then is that rights holders should not be overprotected at the expense of users, and that users should be recognized as rights holders. ${ }^{152}$

This principle of balance in Canada's national copyright law accords with international human rights agreements, which emphasize that states have these two competing but reconcilable obligations to both authors and users. As the United Nations Committee on Economic, Social and Cultural Rights has iterated, states are "obliged to strike an adequate balance" between their obligations to authors, on the one hand, and to users on the other, "with a view to promoting and protecting the full range of rights" 153 guaranteed in the International Covenant on Economic, Social and Cultural Rights. ${ }^{154}$ "In striking this balance, the private interests of authors should not be unduly favoured and the public interest in enjoying broad access to their productions should be given due consideration." ${ }^{155}$ Canada's copyright law therefore must ensure that both users' human rights, to "participate in the cultural life of the community, to enjoy the arts and to share in scientific advancement and its benefits," and authors' human rights, to enjoy "the protection of the moral and material interests” resulting from their intellectual production, are equally recognized. ${ }^{156}$

No doubt the process of satisfying these dual allegiances to authors and to users can at times resemble a pushmi-pullyu, ${ }^{157}$ and, like many other countries, Canada has had a mixed history in this respect. Canada's approach to international copyright law might be described as unpredictable, if not contradictory, with notable moments of strong support for rights holders, authors, developed countries, and intellectual property industries, while at other times there are striking moments of strong support for users, developing countries, and access to knowledge. ${ }^{158}$ On the one hand, Canada's participation in the ACTA negotiations may be

CCH, ibid at para 23. See also Théberge, supra note 148 at paras 30-32; SOCAN, supra note 148 at para 40. For a full discussion of the principle of balance in Canadian copyright law, see Daniel J Gervais, “The Purpose of Copyright Law in Canada” (2005) 2:2 U Ottawa L Tech J 315.

Théberge, ibid at para 31 .

See $C C H$, supra note 148 at para 48.

UNESC, Committee on Economic, Social and Cultural Rights, General Comment No 17: The right of everyone to benefit from the protection of the moral and material interests resulting from any scientific, literary or artistic production of which he or she is the author (article 15, paragraph (1)(c) of the Covenant), 35th Sess, UN Doc E/C.12/GC/17 (2006) at paras 4, 35 [UNESC, General Comment]. International Covenant on Economic, Social and Cultural Rights, 16 December 1966, 993 UNTS 3, (entered into force 3 January 1976) [ICESCR].

UNESC, General Comment, supra note 153 at para 35:

States parties are therefore obliged to strike an adequate balance between their obligations under article 15, paragraph 1 (c), on one hand, and under the other provisions of the Covenant, on the other hand, with a view to promoting and protecting the full range of rights guaranteed in the Covenant. In striking this balance, the private interests of authors should not be unduly favoured and the public interest in enjoying broad access to their productions should be given due consideration.

See Resolution, Universal Declaration of Human Rights, GA Res 217(III), UNGAOR, 3d Sess, Supp No 13, UN Doc A/810, (1948) 71, art 27 [UDHR]. See also ICESCR, supra note 154, art 15.

Hugh Lofting, The Story of Doctor Doolittle (New York: Frederick A Stokes Company, 1920). The pushmi-pullyu was a four-legged creature with two heads on each end of its body that faced in opposite directions.

See Howard Knopf, “Towards A Positive Agenda for International Copyright Reform from a Developed Country's Perspective," (Paper delivered at the UNCTAD-ICTSD Dialogues on IPRs and Sustainable Development: Intellectual Property and Sustainable Development: Revising the Agenda in a New Context) (24-28 October 2005) at 4, online: IPRsonline.org <http://www.iprsonline.org/unctadictsd/ 
cited as compelling evidence of the country's support for stronger international copyright protection and enforcement. Indeed, intellectual property protection was singled out for mention in the 2010 Throne Speech, as Canada articulated its commitment to "strengthen laws governing intellectual property and copyright." 159 In the same vein of rights-holder oriented actions, Canada played a key role along with other Quad members (Japan, US, and EU) to structure the TRIPS Agreement to facilitate the interests of the intellectual property industry, ${ }^{160}$ signed the WIPO Internet Treaties, and subsequently introduced legislation designed to satisfy Canada's obligations under those treaties. ${ }^{161}$ Canada was one of nine countries to reject the Stockholm Protocol, the first practical attempt to make the Berne Convention more mindful of developing countries' interests in access to knowledge, ${ }^{162}$ and the country's position on the WIPO Development Agenda can be described as discouraging, if not opposing. ${ }^{163}$

On the other hand, one can point to Canadian positions that have been oriented toward users or have endorsed greater access to knowledge in international intellectual property. Early on, Canada took a strong stance in support of Canadian readers by threatening to withdraw from the Berne Convention, a move that would have endangered the first union for the protection of copyright. ${ }^{164}$ Although Canada signed the WIPO Internet Treaties in 1997, it is also true that necessary amendments to implement them were delayed for many years, accounting for one of the reasons that Canada regularly appears on the annual Special 301 Report, where the USTR identifies countries that do not provide adequate and effective protection for intellectual property rights or that fail to provide fair and equitable market access for companies relying on intellectual property rights. ${ }^{165}$ Canada has also been supportive of such international efforts as the free and open source movement in the World

bellagio/docs/KNOPFfinal.pdf> [Knopf, “Towards A Positive Agenda”]. Knopf describes Canada as a country of "a long history of ambivalence in its IP policies.” He gives the previous compulsory licencing regime for pharmaceuticals available in Canada up to 1987 and the lack of a retransmission regime in Canada prior to 1989 as examples of areas where Canada's protection of intellectual property was weak.

See "Speech from the Throne: A Stronger Canada, A Stronger Economy: Now and for the Future" (3 March 2010), online: Government of Canada <http://www.speech.gc.ca/eng/media.asp?id=1388>. See Report of the Standing Committee on Canadian Heritage, supra note 65 at 7 (Minister Van Loan emphasizing before the Committee Canada's commitment to provide strong protection of intellectual property rights). See Peter Drahos with John Braithwaite, Information Feudalism: Who Owns the Knowledge Economy? (London: Earthscan, 2002) at 128-37; see also Duncan Matthews, Globalising Intellectual Property Rights: The TRIPs Agreement (London: Routledge, 2002) at 38-39.

$161 \quad$ Bill C-11, supra note 37.

162 Stockholm Protocol, supra note 99. The other eight countries were: Denmark, Finland, West Germany, Israel, Spain, Sweden, Switzerland, and the UK. See Ruth L Okediji, "Sustainable Access to Copyrighted Digital Information Works in Developing Countries” in Keith E Maskus \& Jerome H Reichman, eds, International Public Goods and Transfer of Technology: Under a Globalized Intellectual Property Regime (Cambridge, UK: Cambridge University Press, 2005) 142 at 157.

See Sara Bannerman, “The Development Agenda at WIPO: Where Is Canada?” in Glen Toner, ed, Innovation, Science, Environment: Canadian Policies and Performance, 2008-2009(Montreal: McGillQueen's University Press, 2008) 190 at 200; James Love, "Canada, US and Italy on [Access to Knowledge] in PCDA discussions” (13 June 2007), online: Knowledge Ecology International <http://keionline.org/node/183>; Michael Geist, “Is Canada Against Access to Knowledge?” (13 June 2007), online: Michael Geist <http://www.michaelgeist.ca/content/view/2024/125/>. See Catherine Seville, The Internationalisation of Copyright Law: Books, Buccaneers and the Black Flag in the Nineteenth Century (New York: Cambridge University Press, 2006) at 117-18 (quoting Sir Henry Bergne, the British Delegate to the Berne Conference).

See e.g. USTR, 2011 Special 301 Report (2 May 2011), online: USTR <http://www.ustr.gov/ webfm_send/2841> at 27 [Special 301 Report] (placingApril 16, 2012 Canada on the priority watch list for, inter alia, not implementing the WIPO Internet Treaties). 
Summit on the Information Society (WSIS) ${ }^{166}$ and, with respect to patents, affordable access to essential medicines for developing and least developed countries. ${ }^{167}$ Finally, while the 2011 Throne Speech still included a reference to seeking "swift passage of copyright legislation," this time the speech appended the important qualification that it be legislation "that balances the needs of creators and users." 168

Joining the ACTA negotiations is no doubt more suggestive of a country whose international copyright policy overlaps with the agenda advanced by the agreement's other industrial countries, and the impact of this identification at the international level could lead to a shift in Canadian copyright policy at the national level. Recently, the then-Minister of Industry, Honourable Tony Clement, emphasized that Canada's copyright law compliance with international treaties would be "a made-in-Canada way," not merely an imitation of EU or US law. ${ }^{169}$ In the following Part, we engage in a detailed examination of ACTA's civil enforcement, border measures, criminal enforcement, and digital environment enforcement provisions and their implications for Canadian copyright law. We identify which of ACTA's obligations are satisfied by the Copyright Modernization Act and recommend "made-inCanada" ways to satisfy the mandates in a manner that will respect national and international principles of copyright balance. It must be borne in mind, however, that the flexibility to implement a made-in-Canada policy is of course limited by the mandatory obligations in ACTA, and that ACTA may fairly be described as having a strong rights-holder orientation both in its overall objectives and in its specific provisions. That is, a "made-in-Canada" implementation will not alter the overall TRIPS-plus model of intellectual property protection and enforcement in ACTA. As the European Parliament's July 2011 ACTA study noted, it is possible for a country to adhere to ACTA without jeopardizing its compliance with TRIPS, but because $A C T A$ is rights-holder oriented, incorporates non-binding provisions, and does not detail the relationship between ACTA and TRIPS, implementation demands special care

WSIS was held in Tunisia in November 2005. See William New, "Open Source Agreed In UN Information Society Summit Preparations” Intellectual Property Watch (10 October 2005), online: IP Watch <http://www.ip-watch.org/weblog/2005/10/10/open-source-agreed-in-un-information-societysummit-preparations/>. See also Knopf, "Towards A Positive Agenda for International Copyright Reform, supra note 158 at 5.

"Canada's Access to Medicines Regime (CAMR)," online: CAMR <http://www.camr-rcam.gc.ca/ index_e.html>. CAMR implemented the WTO's August 2003 decision on the Implementation of Paragraph 6 of the Doha Declaration on the TRIPS Agreement and Public Health: Decision of the General Council of 30 August 2003, (WT/L/540 and Corr.1), (1 September 2003), online: WTO <http://www.wto.org/english/tratop_e/trips_e/implem_para6_e.htm>). Under CAMR, Canada passed amendments to its Patent Act, supra note 124, and its Food and Drugs Act, RSC 1985, c F-27, allowing the issuance of compulsory licences, subject to certain conditions, to Canadian pharmaceutical companies to produce generic copies of essential drugs to be exported to some developing and least developed countries; see Bill C-9, An Act to amend the Patent Act and the Food and Drugs Act, 3d Sess, 37th Parl, 2004 (assented to 14 May 2004). Rwanda was the first country to benefit from the Canadian access to medicine regime. Rwanda-Notification under Paragraph 2(A) of the Decision of 30 August 2003 on the Implementation of Paragraph 6 of the Doha Declaration on the TRIPS Agreement and Public Health, (WTO Doc IP/N/9/RWA/1) (19 July 2007); Canada-Notification under Paragraph 2(C) of the Decision of 30 August 2003 on the Implementation of Paragraph 6 of the Doha Declaration on the TRIPS Agreement and Public Health, (WTO Doc IP/N/10/CAN/1) (5 October 2007). "Speech from the Throne: Here for all Canadians - Stability. Prosperity. Security" (3 June 2011), online: Government of Canada <http://www.speech.gc.ca/eng/media.asp?id=1390>. See "Power Play: Industry Minister Tony Clement" (video clip) (3 March 2010), online: CTV $<$ http://watch.ctv.ca/news/power-play/march-3/\#clip272152>. See also Jonathan Migneault, “Government will not accede to ACTA unless 'fully satisfied' that it's in best interest of Canadians: Van Loan” (27 January 2010), online: The Wire Report <http://www.thewirereport.ca/reports/content/10248government_will_not_accede_to_acta_unless_\%E2\%80\%98fully_satisfied\%E2\%80\%99_that_it\%E2\% 80\%99s_in_best_interest> (reporting that Minister Van Loan stated that "[t]he Anti-Counterfeiting Trade Agreement would comply with Canadian law," and that "[b]efore acceding to any agreement, our government would need to be fully satisfied that it reflects the best interests of Canadians"). 
by the legislature. ${ }^{170}$ Consequently, according to the study, although the "letter of the agreement is not incompatible with the [EU] Acquis ... there are no guarantees that its implementation will be": ${ }^{171}$

Parties can implement national legislation that complies with both the ACTA and the TRIPS Agreement. However, while ACTA purports to build on the TRIPS Agreement, it does not, except in the most general terms (Article 1 ACTA), establish a consistent and workable framework for reading the two agreements together. Thus what may first appear to be gaps in ACTA may actually be filled by the TRIPS Agreement. That these gaps always seem to be those that establish safeguards or limits on rightholder action only emphasize the importance to the EU legislator of ensuring a proper reading of the two agreements together. $^{172}$

Likewise, it is incumbent on Canada's Parliament when considering ACTA to ensure that the manner of implementation is TRIPS-compliant and that safeguards and limitations to protect the rights and interests of users are incorporated.

It is also important to note that, although copyright balance has international human rights dimensions, the principle of copyright balance that the Supreme Court of Canada has articulated is a judicial interpretation of principles in the existing Copyright Act, which was not overtly given a constitutional dimension by the Court. Further, this principle of Canadian copyright balance is a recently articulated judicial interpretation of the Canadian statute: a few decades ago the Supreme Court had held that the Copyright Act "was passed with a single object, namely, the benefit of authors of all kinds." Canadian copyright law can be changed by Parliament to comply with international copyright obligations, including to ratify a rights-holder oriented agreement such as ACTA, providing that the amendments do not conflict with Canadian constitutional law or international human rights law principles. Moreover, the Supreme Court has emphasized the role that international copyright law plays when Canadian courts interpret the Copyright Act. As Justice Binnie wrote in Théberge: "In light of the globalization of the so-called 'cultural industries', it is desirable, within the limits permitted by our own legislation, to harmonize our interpretation of copyright protection with other like-minded jurisdictions." ${ }^{174}$ Hence, while ACTA's immediate effect on Canadian copyright policy may be seen in the legislative amendments that are enacted for the agreement's ratification, ACTA's full impact, and the evidence of any practical shift in Canadian copyright policy, may be evident only over time, when the policies of like-minded jurisdictions and judicial interpretations may begin to draw closer together and perhaps a more pronounced rights-holder orientation emerges.

ACTA Assessment, supra note 15 at 8.

Ibid.

Ibid at 7.

See Bishop v Stevens, [1990] 2 SCR 467 at 478. See also Teresa Scassa, "Interests in the Balance" in Michael Geist, ed, In The Public Interest: The Future of Canadian Copyright Law (Toronto: Irwin Law, 2005) 41 at 45-46 (noting that from a constitutional perspective the legislator is free to draft legislation that expressly departs from the principle of balance, and that the repeated enunciation of the principle "reveals a lack of certainty as to both the precise interests in the balance and the rationale for balancing them").

174 Théberge, supra note 148 at para 6. See also Daniel J Gervais, "The Role of International Treaties in the Interpretation of Canadian Intellectual Property Statutes" in Oonagh E Fitzgerald, ed, The Globalized Rule of Law: Relationships between International and Domestic Law (Toronto: Irwin Law, 2006) 549 at 571 . 
The following Part provides a detailed comparison of ACTA's obligations and the Copyright Act, with special consideration of the amendments in the Copyright Modernization Act, and identifies which of ACTA's obligations require further amendments to Canada's copyright law. Drawing on the lessons from the lengthy digital copyright reform process that culminated in the introduction of Bill C-11's Copyright Modernization Act, we suggest how Canada could satisfy ACTA's requirements to protect and enforce copyright while respecting users' rights and preserving the principle of copyright balance.

\section{THE IMPACT OF ACTA'S LEGAL FRAMEWORK ON CANADIAN COPYRIGHT LAW}

The legal framework of ACTA unfolds in its second chapter, which includes a section of general principles and four other sections dealing with civil enforcement, criminal enforcement, border measures, and enforcement of intellectual property in the digital environment. According to the general principles provided in the first section of the second Chapter, the enforcement procedures adopted pursuant to the legal framework of the agreement need to be effective to an extent that deters future infringements of the intellectual property rights covered in the agreement. At the same time, these procedures also need to provide safeguards against abuse and should not stifle legitimate trade. ${ }^{175}$ They must be "fair and equitable," not "unnecessarily complicated or costly," and not involve "unreasonable time-limits or unwarranted delays." 176 Additionally, there is a proportionality principle requiring proportionality between these enforcement measures, the seriousness of the infringement, and the interests of third parties involved. ${ }^{177}$ This guiding principle on proportionality is applicable to the entire second Chapter, not merely to the civil and criminal enforcement sections as some negotiating countries had proposed in previous drafts of the agreement. ${ }^{178}$

ACTA, supra note 2, art 6.1:

Each Party shall ensure that enforcement procedures are available under its law so as to permit effective action against any act of infringement of intellectual property rights covered by this Agreement, including expeditious remedies to prevent infringements and remedies which constitute a deterrent to further infringements. These procedures shall be applied in such a manner as to avoid the creation of barriers to legitimate trade and to provide for safeguards against their abuse.

C.f. TRIPS, supra note 3, art 41.1:

Members shall ensure that enforcement procedures as specified in this Part are available under their law so as to permit effective action against any act of infringement of intellectual property rights covered by this Agreement, including expeditious remedies to prevent infringements and remedies which constitute a deterrent to further infringements. These procedures shall be applied in such a manner as to avoid the creation of barriers to legitimate trade and to provide for safeguards against their abuse.

ACTA, ibid, art 6.2: "Procedures adopted, maintained, or applied to implement the provisions of this Chapter shall be fair and equitable, and shall provide for the rights of all participants subject to such procedures to be appropriately protected. These procedures shall not be unnecessarily complicated or costly, or entail unreasonable time-limits or unwarranted delays.” C.f. TRIPS, ibid, art 41.2: "Procedures concerning the enforcement of intellectual property rights shall be fair and equitable. They shall not be unnecessarily complicated or costly, or entail unreasonable time-limits or unwarranted delays.” ACTA, ibid, art 6.3: "In implementing the provisions of this Chapter, each Party shall take into account the need for proportionality between the seriousness of the infringement, the interests of third parties, and the applicable measures, remedies and penalties.”

See e.g. ACTA: August 2010 Leaked Draft, supra note 52, ch 2, art 2.X(3); ACTA: July 2010 Leaked Draft, supra note 51, ch 2, art 2.X(3); ACTA: April 2010 Consolidated Text, supra note 14, ch 2, s 1, art 2.3(4) (discussing proportionality under the section of civil enforcement). See the Commission Services Working Paper, "Comment on the 'Opinion of European Academics on Anti-Counterfeiting Agreement'” (27 April 2011) at 8, online: EC < http://trade.ec.europa.eu/doclib/docs/2011/april/tradoc_ 147853.pdf> stating:

This general requirement [of the proportionality principle] applies to all parts of ACTA, a fortiori 
These general principles that start the legal framework of ACTA are borrowed from the TRIPS Agreement, ${ }^{179}$ and, at least facially, present ACTA as a regime that considers the interests of the intellectual property rights holders in conjunction with other interests. These principles are supposed to provide member states with some discretion to balance the conflicting interests and/or values underlying intellectual property infringement cases. However, in practice, it could be challenging for legislators both to give due respect to generally applicable principles in ACTA, such as the proportionality principle, ${ }^{180}$ and, at the same time, to fully enforce such substantive provisions as the ones pertinent to statutory damages. ${ }^{181}$ Notwithstanding the presence of comparable flexible provisions in TRIPS, for example, it is difficult to argue that TRIPS qualifies as a "balanced" regime. ${ }^{182}$ Indeed, the status quo of international copyright law indicates that practically reconciling the interests of rights holders with other interests and values (such as free expression and privacy) is challenging within an intellectual property norm-setting mechanism that is oriented toward rights holders. ${ }^{183}$

The four sections of ACTA's legal framework - civil enforcement, border measures, criminal enforcement, and enforcement in the digital environment - were the core focus for the ACTA negotiating countries and were constantly evolving over the course of the negotiations. Significantly, their prospective effect on Canadian copyright law gradually shrank over the rounds of negotiations, and some obligations related to digital copyright have already been addressed by the copyright reform amendments in Bill C-11, which was introduced after the ACTA negotiations were completed. However, ACTA ratification still requires that Canada enact further legislative changes respecting intellectual property enforcement. For each section of the legal framework, we describe ACTA's provisions and requirements and examine their effect on Canadian copyright law.

to all sections under Chapter II of ACTA on the "legal framework for enforcement of IPRs". During the negotiations, it was agreed among the Parties that making additional references to the proportionality principle in other provisions of ACTA was not only unnecessary but could also raise questions as to the applicability of the general requirement whenever a specific reference was lacking [emphasis omitted].

TRIPS, supra note 3, arts 41.1-41.2, 42. See also art 46 on “Other Damages”: "In considering such requests [for disposal of infringing goods and materials predominantly used to create infringing goods], the need for proportionality between the seriousness of the infringement and the remedies ordered as well as the interests of third parties shall be taken into account.”

ACTA, supra note 2 , art 6.3 , requiring proportionality between the seriousness of the infringement, the interests of third parties, and the applicable measures, remedies and penalties. Ibid, art 9.3.

182 See Gerhart, supra note 76; Yu, "International Enclosure Movement,” supra note 79; Dreyfuss, "TRIPSRound II," supra note 81; Dinwoodie \& Dreyfuss, supra note 81; Abbott, "Enduring Enigma of TRIPS," supra note 81. In the "grand bargain" of the GATT Uruguay Round of trade negotiations, which created the WTO and resulted in the TRIPS Agreement, developed countries agreed to open their markets for agriculture and textiles (which would advantage developing countries as exporters) in exchange for intellectual property rights being included in the international trade regime (which would favour developed countries). Developing countries have been disappointed with the subsequent market access for agriculture and textiles, and countries such as China and Brazil have since rigorously advocated that development issues (such as access to medicine) be considered in conjunction with intellectual property protection and enforcement.

183 Peter K Yu, "Currents and Crosscurrents in the International Intellectual Property Regime” (2004) 38:1 Loy LA L Rev 323 at 390-91. It should be noted that specific reference is made in ACTA's digital enforcement section to "fundamental principles such as freedom of expression, fair process, and privacy,” ACTA, supra note 2, arts 27.2-27.4, which is discussed in Part V.D. 


\section{A. CiVIL ENFORCEMENT}

Section 2 of ACTA's legal framework covers the availability of civil enforcement, injunctions, damages, other remedies, information related to infringement, and provisional measures. Given that intellectual property rights are private rights, ${ }^{184}$ most infringement of intellectual property rights will constitute a civil, rather than a criminal, cause of action, and thus be governed by this section. ACTA's civil enforcement requirements should not have a large impact on Canadian copyright law. The Copyright Act now provides rights holders with a wide range of remedies that include the measures that ACTA requires in its civil enforcement section. Copyright owners whose rights have been infringed are entitled to "all remedies,” including injunctions, compensatory and punitive damages, account of profits, and delivery up of infringing goods. ${ }^{185}$

One of the controversial issues under the civil enforcement section during the ACTA negotiations was the scope of the intellectual property rights to which it would apply: namely, whether its scope would be limited to "copyrights and related rights and trademarks," 186 an option that Canada favoured, or if it would be extended to cover all intellectual property. ${ }^{187}$ In the final compromise, the section covers all categories of “intellectual property," but member states are free to exclude patents and undisclosed information. ${ }^{188}$ Some civil enforcement provisions are further limited so they are obligatory only to copyright in some provisions, ${ }^{189}$ or to copyright, related rights, and trademarks in others. ${ }^{190}$ Another controversial matter was whether civil enforcement taken pursuant to this section would be an administrative or judicial procedure. In the final version, members are obliged to make civil judicial procedures for the enforcement of intellectual property rights available to rights holders, ${ }^{191}$ and, if civil remedies can issue from an administrative procedure on the merits of a case, those procedures must "conform to principles equivalent in substance" to those that are described for civil judicial proceedings. ${ }^{192}$

ACTA's injunctions provisions oblige member states to grant their judicial authorities the ability to issue an order against a party ${ }^{193}$ to desist infringing and to issue orders to parties, or, where appropriate, third parties over whom the court has jurisdiction, to keep infringing goods outside the channels of commerce. ${ }^{194}$ Earlier proposed language suggesting that injunctions could issue against intermediaries whose services are used by third parties to

TRIPS, supra note 3, Preamble.

Copyright Act, supra note 1, s 34(1). Section 35(1) provides that the copyright owner can ask for both damages and account of profits.

In addition to Canada, the US, New Zealand, Singapore, and Australia were in favour of this option; see ACTA: August 2010 Leaked Draft, supra note 52, ch 2, s 1, art 2.1(1); ACTA: July 2010 Leaked Draft, supra note 51, ch 2, s 1, art 2.1(1).

Japan, Switzerland, and the EU were in favour of this option. See ACTA: August 2010 Leaked Draft, ibid, ch 2, s 1, art 2.1(1); ACTA: July 2010 Leaked Draft, ibid, ch 2, s 1, art 2.1(1).

ACTA, supra note 2 , art 7.1 and $\mathrm{n} 2$.

See e.g. ibid, art 9.3(c).

See e.g. ibid, arts 9.2-9.3, 9.5.

Ibid, art 7.1

Ibid, art 7.2 .

The agreement uses "party" here, which differentiates it from references to the member states, which are referred to as "Party." C.f. ACTA, ibid, arts 12.1(a), 12.2.

ACTA, ibid, art 8.1. TRIPS, supra note 3 , art 44.1 on injunctions refers to infringing parties and not third parties. 
infringe intellectual property rights was deleted. ${ }^{195}$ In addition to standard injunctions, Canada's Copyright Act also provides for wide injunctions, whereby a court, when granting an injunction for copyright infringement, may further enjoin the defendant from infringing the copyright in any other work (including works that did not exist when the proceedings were commenced) if the plaintiff is the copyright owner of that work or has a grant of an interest by licence and "satisfies the court that the defendant will likely infringe the copyright in those other works or subject-matter unless enjoined by the court from doing so.”196

ACTA's damages provisions embrace both intentional and negligent infringement, but refrain from targeting innocent infringement, ${ }^{197}$ although the latter was once a possibility in an earlier draft. ${ }^{198}$ Article 9.1 of ACTA uses the same language to describe potential defendants as in TRIPS, which likewise refrains from targeting innocent infringement: "an infringer who knowingly, or with reasonable grounds to know, engaged in infringing activity." 199 However, the civil damages provisions of ACTA cover conscious infringement even when it is non-commercial in nature. ${ }^{200}$ Noticeably, even if ACTA had targeted innocent infringers, this would not have caused any noncompliance concerns for Canadian copyright law. Although the Copyright Act takes into consideration the knowledge or intention of the infringer in certain instances, such as in imposing criminal penalties and for certain remedies, Canadian copyright law as a general rule does not treat innocent infringement as a different category of infringement. The Copyright Act makes it an infringement to do, without the consent of the right holder, any of the exclusive rights granted to rights holders under the Copyright Act. ${ }^{201}$ Knowledge of the infringement or intention to infringe is not a condition to finding that infringement of copyright has been established. In fact, Canadian courts have found that "unconscious copying" may constitute infringement. ${ }^{202}$ However, innocent infringement does limit the plaintiff's remedies: if the defendant was not aware and had no reasonable ground for suspecting there was copyright, damages are not available and the plaintiff is entitled only to an injunction. ${ }^{203}$ This limitation does not apply if the copyright is registered. Further, the court may reduce the minimum award for statutory damages to \$200 for innocent infringement. ${ }^{204}$

According to Article 9.1 of ACTA, judicial authorities must have the authority to order infringers, who knowingly infringe or have reasonable grounds to know that they are infringing, to pay the right holder damages in an amount "adequate to compensate for the

See e.g. ACTA: August 2010 Leaked Draft, supra note 52, ch 2, s 1, art 2.X(2); ACTA: July 2010 Leaked Draft, supra note 51, ch 2, s 1, art 2.X(2); ACTA: April Consolidated Text, supra note 14, ch 2, s 1, art 2.X(2).

Copyright Act, supra note 1, s 39.1 .

ACTA, supra note 2, art 9.1.

See ACTA: April 2010 Consolidated Text, supra note 14, ch 2, s 1, art 2.2(1)(a).

TRIPS, supra note 3, art 45.1: "The judicial authorities shall have the authority to order the infringer to pay the right holder damages adequate to compensate for the injury the right holder has suffered because of an infringement of that person's intellectual property right by an infringer who knowingly, or with reasonable grounds to know, engaged in infringing activity.”

By contrast, parties are obliged to apply the criminal provisions only to "wilful trademark counterfeiting or copyright or related rights piracy on a commercial scale.” ACTA, supra note 2, art 23.1 [emphasis added].

Copyright Act, supra note 1, s 27(1).

Gondos v Hardy (1982), 64 CPR (2d) 145 (Ont H Ct J); see also Elizabeth F Judge \& Daniel J Gervais, Intellectual Property: The Law in Canada, 2d ed (Toronto: Carswell, 2011) at 157.

Copyright Act, supra note 1, s 39.

Ibid, ss 38.1-38.2, 38.5. 
injury the right holder has suffered as a result of the infringement."205 To determine that amount, courts may consider "any legitimate measure of value the right holder submits," including lost profit, the market price of the infringed goods or services, and their suggested sale price. ${ }^{206}$ Member states are also obliged to give courts the authority to order the infringer, at least in cases of trademark counterfeiting and copyright or related rights infringement, to pay the rights holders all the infringer's profit ensuing from the infringement. ${ }^{207}$ A party may presume that the infringer's profits are equal to the amount of damages as calculated in Article 9.1.

A major obligation that ACTA imposes on its members is to establish a system, at least for copyright, related rights, and trademark infringement, that provides rights holders with one or more of the following: statutory damages, presumptions for calculating damages, or, at least for copyright, additional damages. ${ }^{208}$ Where statutory damages or presumptions are made available by a party, either the right holder or the judicial authorities must be given the option to choose that as an alternative to damages or profits. ${ }^{209}$ Canadian copyright law is already compliant with this requirement. The Canadian Copyright Act has a statutory damages regime, which can be elected as an alternative to damages and profits. ${ }^{210}$ The current range of statutory damages is between $\$ 500$ and $\$ 20,000$ per work infringed. ${ }^{211}$ When the

ACTA, supra note 2, art 9.1.

Ibid. The ACTA Assessment, supra note 15 at 52 observes that market price and suggested retail price, both proxies for the idea that infringing product represents a lost sale, are novel problematic approaches that are not within the EU Intellectual Property Rights Enforcement Directive. Directives EC, Directive 2004/48/EC of the European Parliament and of the Council of 29 April 2004 on the enforcement of intellectual property rights, [2004] OJ, L 157/45 (30 April 2004), online: EUR-Lex <http://eur-lex. europa.eu/Result.do?RechType=RECH_celex\&lang=en\&ihmlang=en\&code=32004L0048>.

ACTA, supra note 2 , art 9.2 .

Ibid, art 9.3. Footnote 3 to article 9.3 provides with respect to presumptions:

The presumptions referred to in subparagraph 3(b) may include a presumption that the amount of damages is: (i) the quantity of the goods infringing the right holder's intellectual property right in question and actually assigned to third persons, multiplied by the amount of profit per unit of goods which would have been sold by the right holder if there had not been the act of infringement; or (ii) a reasonable royalty; or (iii) a lump sum on the basis of elements such as at least the amount of royalties or fees which would have been due if the infringer had requested authorization to use the intellectual property right in question.

Ibid, art 9.4.

Copyright Act, supra note 1, s 35 provides for damages and, in addition to damages, part of the infringer's profits "that were not taken into account in calculating the damages as the court considers just." Statutory damages are provided for in section 38.1 as an alternative that the right holder may elect in lieu of section 35 damages and profits. Section 38.1 provides:

(1) Subject to this section, a copyright owner may elect, at any time before final judgment is rendered, to recover, instead of damages and profits referred to in subsection 35(1), an award of statutory damages for all infringements involved in the proceedings, with respect to any one work or other subject-matter, for which any one infringer is liable individually, or for which any two or more infringers are liable jointly and severally, in a sum of not less than $\$ 500$ or more than $\$ 20,000$ as the court considers just.

Bill C-11 lowers the range of statutory damages for non-commercial uses to a ceiling of $\$ 5,000$ and a floor of \$100. Bill C-11, supra note 39, s 46, proposing amendments to ss 38.1(1)-(3). Unlike Bill C-60, Bill C-61 would have put a \$500 cap for the statutory damages that could be awarded to plaintiffs for non-commercial infringements. See Bill C-61, supra note 147, s 30(1), proposing amendments to s 38.1(2). The underlying policy behind the system of statutory damages is to overcome the economic and evidentiary hurdles that rights holders face in proving actual damages. See Telewizja Polsat SA v Radiopol Inc, 2006 FC 584, [2007] 1 FCR 444 at para 40 [Radiopol Inc]. See also, Judge \& Gervais, supra note 202 at 1046; Pamela Samuelson \& Tara Wheatland, "Statutory Damages in Copyright Law: A Remedy in Need of Reform” (2009) 51:2 Wm \& Mary L Rev 439 at 510. However, this system has been described as "frequently arbitrary, inconsistent, unprincipled, and sometimes grossly excessive" (ibid at 441).

See e.g. Louis Vuitton Malletier SA v Yang, 2007 FC 1179, 62 CPR (4th) 362, awarding the maximum statutory damages of $\$ 20,000$ for each of the two copyrighted works infringed by the defendants; Film City Entertainment Ltd v Chen, 2006 FC 1150, 300 FTR 94, awarding statutory damages in the amount of \$5,000 against the defendants who infringed the plaintiffs' copyright in a TV program; Nicholas $v$ 
court is convinced that the defendant was unaware of the infringement or had no reasonable grounds to believe that they were infringing copyrights, the court may reduce the minimum of the statutory damages to $\$ 200$ per work. ${ }^{212}$ In special cases, the Copyright Act allows courts to reduce the statutory damages awarded below the stated minimums ( $\$ 500$ and $\$ 200$ ) when the infringement both involves more than one work in one single medium and the awarding of these minimums would be "grossly out of proportion to the infringement." 213 The incorporation of such judicial discretion in the Canadian statutory damages system would not conflict with the obligations under ACTA, for the agreement does not require a specific mechanism for determining these damages. Further, such discretion is in harmony with the ACTA provisions that the measures adopted pursuant to the agreement's legal framework shall be "fair and equitable" and proportionate to the seriousness of the infringement and the rights of third parties involved. ${ }^{214}$

In addition to the system of statutory damages, Canadian copyright law allows additional damages in the form of punitive or exemplary damages. ${ }^{215}$ Indeed, section 38.1(7) of the Copyright Act expressly allows punitive damages to be awarded even if a plaintiff elects statutory damages in lieu of damages and profits. The Supreme Court of Canada (in a case that did not involve intellectual property) described punitive damages as an exceptional remedy that may be imposed only for "high-handed, malicious, arbitrary or highly reprehensible misconduct that departs to a marked degree from ordinary standards of decent behaviour."216 The Supreme Court emphasized that "proportionality" is the "key to the permissible quantum of punitive damages," 217 and that the amount should be "reasonably proportionate to such factors as the harm caused, the degree of the misconduct, the relative vulnerability of the plaintiff and any advantage or profit gained by the defendant." ${ }^{218}$ The Supreme Court went on to describe the "several dimensions" of "proportionality," including proportionality to the blameworthiness of the defendant's conduct, the degree of the plaintiff's vulnerability, the harm or potential harm directed specifically at the plaintiff, the need for deterrence, the other penalties (both civil and criminal) which have been or are likely to be inflicted on the defendant for the same misconduct, and the advantage wrongfully gained by a defendant from the misconduct. ${ }^{219}$ This measure should easily accord with ACTA's proportionality principle as two of the guidelines in ACTA are explicitly included by the Supreme Court (proportionality between the seriousness of the infringement and the applicable measures, remedies and penalties), and, although the Supreme Court does not expressly mention third party interests, that concept is implicated in the need for deterrence.

Canadian courts have approved punitive damages as a remedy in intellectual property infringement cases, although, as is true generally of punitive damages in Canada, they are

Environmental Systems (International) Ltd, 2010 FC 741, 87 CPR (4th) 83 (awarding only the lower end of the statutory damages scale (\$500)).

Copyright Act, supra note 1, s 38.1(2).

213 Ibid, s 38.1(3). See also Radiopol Inc, supra note 210 (awarding statutory damages at $\$ 150$ per each of the 2009 infringed works).

ACTA, supra note 2, arts 6.2-6.3.

Copyright Act, supra note 1, s 38.1(7).

Whiten v Pilot Insurance Co, 2002 SCC 18, [2002] 1 SCR 595 at para 94 [Whiten]. See also Hill v Church of Scientology of Toronto, [1995] 2 SCR 1130; Vorvis v Insurance Corp of British Columbia, [1989] 1 SCR 1085.

Whiten, ibid at para 111.

Ibid at para 94.

Ibid at paras 111-26. 
rarely awarded. ${ }^{220}$ Showing bad faith prior to or during the legal proceeding amounting to a "callous disregard" for the plaintiff's rights or judicial processes, such as when the defendants continue the infringement in spite of receiving a cease and desist letter, can constitute the requisite misconduct for an award of punitive damages. ${ }^{221}$

Other remedies stated in ACTA's civil enforcement section include granting courts the authority to award rights holders prevailing in a civil procedure costs, fees, and attorney's fees, ${ }^{222}$ which is in harmony with the provisions of the Canadian Copyright Act. ${ }^{223}$ Furthermore, member states' civil remedies must include destroying the infringing goods, ${ }^{224}$ at least in copyright and trademark infringement cases, and destroying the materials predominantly used to make infringing goods, or taking them out of the channels of commerce. ${ }^{225}$ The Copyright Act already grants rights holders the right to recover the infringing copies and the "plates used or intended to be used for the production of infringing copies." ${ }^{226}$ Courts have the power to issue an order for the seizure and destruction of the infringing copies or plates, or any other order that the court considers "appropriate in the circumstances," and shall take into consideration all the circumstances, including the relative value and importance of the infringing copy as compared to the substrate and whether the copy is severable from the substrate. ${ }^{227}$

ACTA also provides that member states must give courts the authority, on a justified request of the right holder, to oblige infringers to provide further information about the infringement, such as the source of the infringing goods, channels of distribution, and any third parties involved. ${ }^{228}$ ACTA maintains important safeguards by providing that such disclosure must not conflict with privilege, confidentiality, or privacy protections, protections that are incorporated not only in Article 11's provision on information related to infringement but are also expressly detailed in the initial provisions in Article 4, which are applicable to

Lubrizol Corp v Imperial Oil Ltd (1992), 45 CPR (3d) 449 (FCA) at para 33; Eli Lilly \& Co v Apotex Inc, (2000), 9 CPR (4th) 439 (FCA) at para 12; Profekta International Inc v Lee (1997), 75 CPR (3d) 369 (FCA) at paras 1-2, 4.

In Louis Vuitton Malletier SA v 486353 BC Ltd, 2008 BCSC 799 at para 86, Justice Boyd provided the following description of defendants' conduct that may be punished by punitive damages:

Punitive and exemplary damages have been awarded in cases of trade-mark and copyright infringement, where, for example, the conduct of the defendants was "outrageous" or "highly reprehensible", or where the defendant's actions constituted a callous disregard for the rights of the plaintiff or for injunctions granted by the Court. Similarly, in determining whether punitive and exemplary damages ought to be awarded, the Court will consider whether the defendant has little regard for the legal process, thus requiring the plaintiff to expend additional time and money in enforcing its rights.

See also Whiten, supra note 216, at para 113 listing factors considered by Canadian courts for the blameworthiness of the defendant's misconduct (which is one of the "dimensions" of proportionality discussed at paras 111-26): "whether the misconduct was planned and deliberate," the defendant's intent and motive, "whether the defendant persisted in the outrageous conduct over a lengthy period of time," "whether the defendant concealed or attempted to cover up its misconduct," "the defendant's awareness that what he or she was doing was wrong," "whether the defendant profited from its misconduct," and "whether the interest violated by the misconduct was known to be deeply personal to the plaintiff (e.g. professional reputation) or a thing that was irreplaceable” [reference omitted]. ACTA, supra note 2 , art 9.5 .

Copyright Act, supra note 1, s 34.3.

ACTA, supra note 2, art 10.1. TRIPS, supra note 3 , art 46 provides for infringing goods and materials used to create infringing goods to be disposed outside the channels of commerce. However, TRIPS art 46 does not provide, as ACTA art 10.3 does, that the remedy may be ordered to be carried out at the infringer's expense. 
the whole agreement. ${ }^{229} \mathrm{~A}$ right of information is also present in Article 47 of TRIPS to order the infringer to inform the right holder "of third persons involved in the production and distribution of infringing goods or services and of their channels of distribution," but TRIPS contains the important caveat "unless this would be out of proportion to the seriousness of the infringement." ${ }^{\text {"230 }}$ Although the Canadian Copyright Act does not have a specific procedural mechanism for such information disclosure, it is within the authority of Canadian courts by virtue of the Federal Courts Rules on examination for discovery. ${ }^{231}$

Finally, Article 12 of ACTA details the "prompt and effective" provisional measures that judicial authorities must be authorized to order, including those to prevent intellectual property infringement from taking place and to preserve relevant evidence relating to an alleged infringement. ${ }^{232}$ Judicial authorities must also have the authority to adopt provisional measures without hearing first from the other side (inaudita altera parte) when a delay is likely to cause irreparable harm to the right holder or where there is a demonstrable risk of evidence being destroyed. ${ }^{233}$ Although this is generally consistent with Article 50.2 of TRIPS, which under similar conditions permits provisional measures to be adopted without a hearing, TRIPS goes on to provide procedural protections that ACTA does not specifically mention under provisional measures; according to TRIPS Article 50.4, after the adoption of these measures, inaudita altera parte, the affected parties shall be given notice without delay, a review, and a right to be heard to decide whether the measures shall be modified, revoked or confirmed. ${ }^{234}$ However, Article 6 of ACTA, which provides general obligations that apply to the whole legal framework of Chapter II, including Article 12 on provisional measures, mandates that procedures "shall be fair and equitable, and shall provide for the rights of all participants subject to such procedures to be appropriately protected." ${ }^{, 235}$ It further provides that the "procedures shall not be unnecessarily complicated or costly, or entail unreasonable time-limits or unwarranted delays." ${ }^{.236}$ Additional safeguards are provided in Article 12.4 of ACTA whereby judicial authorities must have the authority to require an applicant for provisional measures to provide "any reasonably available evidence" to satisfy the court "with a sufficient degree of certainty" that the applicant's right is either being infringed or that infringement is imminent and that judicial authorities shall also have the authority "to order the applicant to provide a security ... sufficient to protect the defendant and to prevent abuse." ${ }^{237}$ This parallels the wording in Article 50.3 of TRIPS, except that ACTA adds a further clause to protect right holders that the security "shall not unreasonably deter recourse" to the procedures to obtain provisional measures. ${ }^{238}$ If the provisional measures are revoked or lapse because of the applicant's act or omission, ACTA provides that an applicant can be ordered to provide the defendant with "appropriate compensation” for injury caused by the provisional measures. ${ }^{239}$

Ibid, arts 4, 11.

TRIPS, supra note 3 , art 47

Federal Courts Rules, SOR/98-106, ss 2, 234, 240.

ACTA, supra note 2, art 12.1. TRIPS, supra note 3 , art 50.1 contains similar language but does not mention, as ACTA art 12.1 does, third parties over whom the judicial authority has jurisdiction.

ACTA, ibid, art 12.2.

TRIPS, supra note 3 , art 50.4 .

ACTA, supra note 2 , art 6.2 .

Ibid.

Ibid, art 12.4.

ACTA, ibid. TRIPS, supra note 3, art 50.3.

ACTA, ibid, art 12.5. 
Three significant provisional remedies in Canada for intellectual property cases are interlocutory injunctions, seizure before judgment, and Anton Piller orders. ${ }^{240} \mathrm{~A}$ three-prong test must be satisfied for interlocutory injunctions in Canada: (1) there must be a serious question to be tried in the main action; (2) the plaintiff will suffer irreparable harm in the absence of an interlocutory injunction; and (3) the balance of convenience as between the parties favours the grant of an injunction against the defendants. ${ }^{241}$ The Copyright Act also provides for a copyright owner to take proceedings for seizure before judgment of infringing copies and plates used or intended to be used to produce infringing copies, providing that the applicable federal or provincial law entitles the person to take those proceedings. ${ }^{242}$ Anton Piller orders, another example of a provisional measure for intellectual property cases, are ex parte interlocutory orders akin to a private search warrant that allow the plaintiff in a civil case to enter a defendant's premises without notice and to seize and preserve evidence. ${ }^{243}$ To be eligible for this extraordinary remedy, a plaintiff must satisfy four conditions. First, the plaintiff must have a strong prima facie case; second, the damage to the plaintiff from the defendant's potential or actual misconduct must be very serious; third, there must be convincing evidence that the defendant possesses incriminating documents or things; and fourth, there is a real possibility that the defendant may destroy such material before the discovery process can effect its purpose. ${ }^{244}$ In the intellectual property context, an Anton Piller order enables a plaintiff to inspect and remove potentially infringing articles. ${ }^{245}$

\section{B. BORDER MEASURES}

The border measures section in ACTA deals with member states' authority with respect to goods that are suspected of infringing intellectual property rights when they are imported, exported, in transit, or under customs supervision. ${ }^{246}$ According to Article 13 on the scope of border measures, members should provide effective enforcement of intellectual property rights "in a manner that does not discriminate unjustifiably between intellectual property rights and that avoids the creation of barriers to legitimate trade."247 Unlike some other sections in ACTA where application is mandatory only for copyright and trademark but can permissibly be applied to patents and undisclosed information, the border enforcement section provides categorically that patents and undisclosed information are excluded from its scope. ${ }^{248}$

Anton Piller KG v Manufacturing Processes Ltd (1975), 1 All ER 779 (CA) [Anton Piller]. RJR-MacDonald Inc v Canada (AG), [1994] 1 SCR 311 at para 29; Manitoba (AG) v Metropolitan Stores Ltd, [1987] 1 SCR 110.

Copyright Act, supra note 1 , s 38.1 .

See Anton Piller, supra note 240.

Celanese Canada Inc v Murray Demolition Corp, 2006 SCC 36, [2006] 2 SCR 189 at para 35 [Celanese Canada]. For the five criteria for a judicial determination as to whether to continue or vacate an issued Anton Piller order, see Netbored Inc v Avery Holdings Inc, 2005 FC 1405, 48 CPR (4th) 241 at paras 39-41.

See Celanese Canada, ibid at para 29 (stating that Anton Piller orders were "[o]riginally developed as an 'exceptional remedy' in the context of trade secrets and intellectual property disputes”).

ACTA, supra note 2, arts 16.1-16.2.

Ibid, art 13.

Ibid, art 13 and $\mathrm{n} 6$. Before patents were excluded from the border measures section, there were serious concerns about ACTA's potential adverse effect on access to medicine and the agreement's negative implications for the Doha Declaration on TRIPS and Public Health. See WTO, Ministerial Conference, Declaration on TRIPS Agreement and Public Health, WTO Doc WT/MIN(01) DEC/2, 4th Sess, 41 ILM 755 (2002) (adopted 14 November 2001) [Doha Declaration on TRIPS and Public Health]. The "Opinion of European Academics," supra note 47 at 3 cautions that even in its final wording, ACTA could be problematic for international trade in generic medicines, unless it is narrowly interpreted and implemented, because all trademark infringements are included in the scope of border measures, not 
For import and export shipments, member states are required to provide procedures enabling rights holders to ask customs authorities to suspend the release of the goods suspected of intellectual property infringement. ${ }^{249}$ Member states are also required to provide their competent authorities with ex officio authority ("may act upon their own initiative" without any request from rights holders) to suspend the release of the suspected infringing goods. ${ }^{250}$ The same required procedures are similarly available with respect to "in transit" shipments or shipments under customs control. ${ }^{251}$ The only difference in the latter context is that authorities, acting upon their own initiative or upon a request from a rights holder, additionally have the option of detaining the suspected infringing goods. ${ }^{252}$

During the ACTA negotiations, Canada favoured limiting the scope of these provisions to shipments suspected of including pirated copyright and counterfeit trademark goods. Canada also proposed to make these measures required only with regard to "import" shipments, but optional in regard to "export" and "in transit” shipments. ${ }^{253}$ The Canadian position, which was supported by New Zealand, Singapore, and Australia, almost mirrors the content of Article 51 of the TRIPS Agreement, which provides that members shall "adopt procedures to enable a right holder, who has valid grounds for suspecting that the importation of counterfeit trademark or pirated copyright goods may take place," to apply to have customs authorities suspend the release of those goods. ${ }^{254}$ However, Article 51 of TRIPS permits members to apply border measures to infringements of other intellectual property rights, as long as the conditions in that section are met. ${ }^{255}$

ACTA includes qualifying provisions to help protect defendants and authorities from abuse of procedures by rights holders. Rights holders must satisfy the competent authority that there is a prima facie case of an infringement of their intellectual property rights and are required "to supply sufficient information that may reasonably be expected to be within the right holder's knowledge to make the suspect goods reasonably recognizable by the competent authorities."256 This threshold accords with Article 52 of TRIPS, which details the application procedure for border measures. ${ }^{257}$ ACTA requires member states to give their competent authorities the power to require a reasonable security from right holders

merely counterfeiting, and thus generic medicine could be seized based on an "ordinary" trademark infringement. But see Commission Services Working Paper, supra note 73 at 9-11, addressing these concerns and identifying "several layers of safeguards [that] should allay the concerns of those who fear that ACTA could adversely affect access to medicines in developing countries" (ibid at 11). ACTA, ibid, art 16.1(b). See also art 17.1.

Ibid, art 16.1(a). On the other hand, granting custom authorities ex officio powers is optional under the TRIPS Agreement. See TRIPS, supra note 3, art 58:

Where Members require competent authorities to act upon their own initiative and to suspend the release of goods in respect of which they have acquired prima facie evidence that an intellectual property right is being infringed: (a) the competent authorities may at any time seek from the right holder any information that may assist them to exercise these powers; (b) the importer and the right holder shall be promptly notified of the suspension. Where the importer has lodged an appeal against the suspension with the competent authorities, the suspension shall be subject to the conditions, mutatis mutandis, set out at Article 55; (c) Members shall only exempt both public authorities and officials from liability to appropriate remedial measures where actions are taken or intended in good faith.

ACTA, supra note 2, art 16.2.

Ibid, arts 16.2(a)-(b).

See ACTA: August 2010 Leaked Draft, supra note 52, ch 2, s 2, art 2.6 (option 3), art 2.7 (option 3). TRIPS, supra note 3 , art 51 [footnote omitted].

TRIPS, ibid, referring to the requirements in TRIPS arts 52-58.

ACTA, supra note 2, art 17.1.

TRIPS, supra note 3 , art 52. 
requesting procedures to detain or suspend the release of goods suspected of infringing their intellectual property rights; however, such security must not "unreasonably deter recourse" to the procedures. ${ }^{258}$ It further gives customs authorities the ability to decide whether the suspended goods suspected of infringement are truly infringing or not. ${ }^{259}$ If the right holder abuses the procedures for suspending goods, member states may provide that the "competent authorities have the authority to deny, suspend, or void an application." 260

ACTA's provisions thus effectively allow the request for a suspension of goods to be initiated on the right holder's discretion if the right holder satisfies a prima facie showing of infringement and conveys enough information to the customs authorities so that the goods are "reasonably recognizable," and provides reasonable security when required to do so. ${ }^{261}$ By contrast, the agreement contains few explicit countervailing procedures for defendants to contest the suspension of goods apart from the general obligations in Article 6 that procedures be "fair and equitable" and that all participants' rights be "appropriately protected." The agreement does not specify that defendants have a right to challenge a suspension of goods before it occurs. Article 19 requires only that there be procedures "after the initiation" of the suspension procedures by which the authorities may determine "within a reasonable period" whether the suspect goods indeed did infringe an intellectual property right. ${ }^{262}$ Moreover, it is only permissive not obligatory for member states to address an applicant's abuse of the suspension procedures, and even there the authorities are authorized only to "deny, suspend, or void an application" and not to impose other penalties on the applicant as a form of deterrence. ${ }^{263}$

However, ACTA's suspension procedures must be interpreted alongside Section 4 of Part III of TRIPS, which contains special requirements for border measures, including safeguards for defendants. Under TRIPS, both the importer and applicant must be accorded notice that the release of goods has been suspended. ${ }^{264}$ TRIPS provides that the goods shall be released if proceedings to decide infringement on the merits have not been initiated within ten working days (which may be extended by another ten working days), and, once the proceedings have been initiated, the defendant has the right to request a review to decide if the suspension measures shall be modified, revoked, or confirmed, and a right to be heard at that review. ${ }^{265}$ If the goods have been wrongfully detained, the authorities also can order the applicant to pay the importer, consignees, and owner of the goods appropriate compensation for any injury. ${ }^{266}$

For remedies upon finding infringement, ACTA provides that authorities may order the destruction of the goods, or if the goods are not destroyed, the goods must be "disposed of

ACTA, supra note 2, art 18. See TRIPS, ibid, art 53 on Security or Equivalent Assurance.

ACTA, ibid, art 19.

Ibid, art 17.4 .

Ibid, arts 17-18.

Ibid, art 19.

Ibid, art 17.4.

TRIPS, supra note 3, art 54 .

Ibid, art 55. There are thus two distinct time periods referenced in TRIPS and ACTA: the ten working days in art 55 of TRIPS refers to the maximum time that the applicant has to initiate proceedings on the merits after the initial detention of the goods, whereas the timing of a "reasonable period" in ACTA, supra note 2 , art 19 refers to when a determination on the merits must be made after those proceedings have been initiated. TRIPS, ibid, art 56. 
outside the channels of commerce" to avoid harm to the rights holders. ${ }^{267}$ To identify infringing shipments, authorities may provide information to the rights holders about goods or specific shipments, as long as it is without prejudice to the countries' laws on privacy and confidential information. ${ }^{268}$ Such information may include the country of origin and the names and addresses of the consignor, importer, exporter, consignee, and the manufacturer. ${ }^{269}$

The border measures section does include an important public interest safeguard: it has a de minimis exception that would allow member states to exclude goods that are noncommercial in quantity and nature and contained in travellers' luggage from the actions described in this section. ${ }^{270}$ This exception quelled the concern that ACTA would subject travellers' luggage, portable computers, and portable media recorders to inspection for copyright-infringing materials. Small consignments of goods of a commercial nature are, however, explicitly excluded from the de minimis exception, and therefore are subject to the procedures described in the border measures section. ${ }^{271}$ ACTA is silent with respect to noncommercial goods sent in small consignments (as opposed to being carried in a traveller's personal luggage). That is, it is left to the member states to decide whether to subject these consignments to ACTA's border measures or to include them within the scope of the de minimis exception. A proposition to extend the de minimis exception to cover noncommercial goods sent in small consignments, which was speculated in some earlier drafts of ACTA, was closer to the larger scope of the de minimis exception under Article 60 of the TRIPS Agreement. ${ }^{272}$

Canada's Copyright Act includes some provisions on border measures. The Copyright Act prohibits certain acts of secondary infringement, including the importation of copies that would have infringed copyright if they had been made in Canada. ${ }^{273}$ The Copyright Act has procedural mechanisms for the copyright owner or exclusive licensee to apply for a court order to stop copies and related rights material at the border that would constitute secondary infringement by importation. ${ }^{274}$ The Copyright Act authorizes courts, as opposed to customs authorities, to order the Minister of Public Safety to take reasonable measures on the basis of information from the applicant to detain the work and to notify the applicant and importer of the detention and the reasons for it. ${ }^{275}$ Consistent with the safeguards in TRIPS, the Copyright Act provides that courts may require security from the applicant to cover the costs of storage and any damage the consignee, owner, or importer incurs as a result of the suspension. ${ }^{276}$ Additionally, if the applicant has not commenced proceedings for a final

ACTA, supra note 2, art 20.1.

Ibid, art 22.

Ibid, art 22(b).

Ibid, art 14.2.

Ibid, art 14.1 .

TRIPS, supra note 3, art 60: "Members may exclude from the application of the above provisions small quantities of goods of a non-commercial nature contained in travellers’ personal luggage or sent in small consignments."

Copyright Act, supra note 1, s 27(2).

Ibid, ss 44, 44.2, 44.4. Section 45 provides exceptions for individuals, government, libraries, archives, museums, and educational institutions to import copies if the relevant copyright owner where they were made consented and also provides exceptions for used books (excluding textbooks) to be imported.

Ibid, s 44.1(3).

Ibid, s 44.1(5). 
judicial determination on the merits within two weeks, the goods shall be released without notice to the applicant. ${ }^{277}$

However, ACTA's more expansive provisions for border measures are not included in Canada's current copyright statute, and thus the agreement could have a conspicuous impact on Canadian copyright law in this domain. The border measures requirements that ACTA is imposing, such as granting customs authorities with ex officio power to suspend the release of suspect goods, could be highly disruptive of established user rights and exceptions under Canadian copyright law, such as fair dealing, where the complex nature of the inquiry demands that the proper preserve for the inquiry be with the courts rather than customs officials. ${ }^{278}$ In addition to endangering the rights of users, ex officio measures also shift costs for enforcing the private rights of intellectual property onto public authorities and thus onto taxpayers. By contrast, ex officio powers for enforcement of intellectual property rights are not obligatory under TRIPS. ${ }^{279}$ The Preamble of TRIPS explicitly emphasizes that "intellectual property rights are private rights" in advance of recognizing the "underlying public policy objectives of national systems for the protection of intellectual property."280 This wording in TRIPS suggests "the desire to make clear that Members were not obliged to take action ex officio, and that title holders should bear the burden of exercising and defending their rights." ${ }^{281}$ As Peter Yu explains:

[U]nlike the heightened international intellectual property enforcement standards that developed countries are now pushing globally through ACTA and other bilateral, plurilateral, or regional trade agreements, the TRIPS Agreement — which codified internationally recognized minimum standards in the early 1990s — did not require the provision of ex officio authority to seize allegedly infringing goods. Indeed, article 58 of

Ibid, s 44.1(8). See also Canada Border Services Agency (CBSA), Memorandum, D19-4-3, “Copyright and Trademarks” (17 June 2008), online: CBSA < http://www.cbsa-asfc.gc.ca/publications/dm-md/d19/ d19-4-3-eng.pdf> [Memorandum D19-4-3] (summarizing the duties of the CBSA under the Copyright Act, the Trade-marks Act, RSC 1985, c T-13, and Customs Tariff, SC 1997, с 36, with regard to counterfeit trademark or pirated copyright goods).

As Howard Knopf aptly described some of the risk associated with granting custom authorities ex offico powers:

A judgment call about whether a particular product is "legal" or not is very often far from clear.

For example, running shoes or handbags may be made "illegally" on the same assembly lines as the "real" product "after hours" and be identical in all physical respects to the "real" product. How is the border official supposed to make the determination as to whether the goods are "legal" or not?... If the best lawyers and judges have to struggle intellectually about whether perfectly legitimate parallel import goods can be legally imported, are we ready to allow border guards with no legal education, and with no prior judicial oversight to make this initial determination and potentially tie up millions of dollars worth of merchandise for great lengths of time, forcing the importer to go to court to get the goods released? Border officials will inevitably be "educated" and provided with information about suspect shipments by those who may have a vested interest in keeping out parallel imports and may even have an interest in causing serious inconvenience to a legitimate competitor.

Howard Knopf, “ACTA, ‘Ex Officio’ Enforcement, and Parallel Imports” (8 September 2010), online: Excess Copyright, <http://excesscopyright.blogspot.ca/2010/09/acta-ex-officio-enforcement-and.html>. See also "International Experts Find that Pending Anti-Counterfeiting Trade Agreement Threatens Public Interests” (23 June 2010), online: American University Washington College of Law <http:// www.wcl.american.edu/pijip/go/acta-communique>.

TRIPS, supra note 3 , art 58 .

Ibid, Preamble [emphasis added].

Correa, supra note 121 at 10 [footnote omitted]. See also Xuan Li, "Ten General Misconceptions about the Enforcement of Intellectual Property Rights” in Xuan Li \& Carlos M Correa, eds, Intellectual Property Enforcement: International Perspectives (Cheltenham, UK: Edward Elgar, 2009) 14 at 27 (stating: "As with any other kind of private rights, the enforcement of IP rights is primarily a matter concerning the individual owners of these rights. It is the primary obligation of right-holders and not government to enforce their claimed rights and take necessary legal actions for protecting their own IPRs”). 
the TRIPS Agreement, which specifically deals with the situation where domestic laws provide for ex officio actions, was included only as a "may" provision. ${ }^{282}$

It should be noted that the US has regularly insisted that Canada provide its customs authorities with ex officio authority to seize goods suspected of infringing intellectual property rights. Canada's failure to do so has been one of the reasons for Canada being placed on the "priority watch list" of the Special 301 Report prepared by the USTR. ${ }^{283}$

\section{CRIMINAL ENFORCEMENT}

Criminal enforcement has been characterized as "easily the most ambitious" part of the ACTA negotiations, especially considered against the backdrop that there is only one article in TRIPS covering the area and no other international standards. ${ }^{284}$ ACTA's section on criminal enforcement obliges member states to criminalize at least "wilful trademark counterfeiting or copyright or related rights piracy on a commercial scale.”285 The scope of this provision is similar to the scope of Article 61 of the TRIPS Agreement, ${ }^{286}$ which has been described as a "flexible international minimum standard" for the criminal enforcement of intellectual property ${ }^{287}$ In an earlier draft of ACTA, it was proposed that the "commercial scale" requirement for the criminalization of copyright and related rights piracy is satisfied not only when piracy is for the purpose of "commercial advantage or financial gain" but also when it is "significant” and "willful," even if it does not have "direct or indirect motivation of financial gain." ${ }^{288}$ In the final version of the agreement, the scope of this provision is narrowed so that the commercial scale requirement is established "at least" in counterfeiting or piracy acts "carried out as commercial activities for direct or indirect economic or commercial advantage.”289 Put differently, according to ACTA’s final wording, member states may, but are no longer required to, criminalize significant wilful piracy or counterfeiting that has no economic or commercial benefit. The narrowed "commercial scale" requirement

Peter K Yu, “TRIPS Enforcement and Developing Countries” (2011) 26:3 Am U Int'l L Rev 727 at 1415, online: SSRN < http://papers.ssrn.com/sol3/papers.cfm?abstract_id=1736030 > [footnotes omitted]. See also Frederick M Abbott, “Trading's End: Is ACTA the Leading Edge Of A Protectionist Wave?” (6 May 2011), online: Intellectual Property Watch <http://www.ip-watch.org/weblog/2011/05/06/ trading\%E2\%80\%99s-end-is-acta-the-leading-edge-of-a-protectionist-wave/> (stating: "Probably the most problematic provisions mandate that customs authorities be enabled to act ex officio to seize 'suspect goods' at the border, without definition of the basis for suspicion, and without mandating that a determination be made regarding the offense the suspect goods allegedly commit”).

See e.g. 2011 Special 301 Report, supra note 165 at 27.

ACTA Assessment, supra note 15 at 55; TRIPS, supra note 3, art 61.

ACTA, supra note 2, art 23.1. This provision also criminalizes wilful importation or exportation of pirated or counterfeited goods on a commercial scale; see ACTA, ibid, art 23.1, n 9.

TRIPS, supra note 3 , art 61:

Members shall provide for criminal procedures and penalties to be applied at least in cases of

wilful trademark counterfeiting or copyright piracy on a commercial scale. Remedies available

shall include imprisonment and/or monetary fines sufficient to provide a deterrent, consistently

with the level of penalties applied for crimes of a corresponding gravity. In appropriate cases,

remedies available shall also include the seizure, forfeiture and destruction of the infringing goods and of any materials and implements the predominant use of which has been in the commission of the offence. Members may provide for criminal procedures and penalties to be applied in other cases of infringement of intellectual property rights, in particular where they are committed wilfully and on a commercial scale.

Henning Grosse Ruse-Khan, "From TRIPS to ACTA: Towards a New 'Gold Standard' in Criminal IP Enforcement?” Max Planck Institute for Intellectual Property and Competition Law Research Paper No 10-06 (17 June 2010) at 17, online: SSRN <http://papers.ssrn.com/sol3/papers.cfm?abstract_id= $1592104>$. 
emphasizes large-scale piracy and softens the impact on individuals who engage in activities with copyrighted works such as file sharing without accruing a benefit financially or commercially, who could have been captured in the initial broader scope of the criminal enforcement provisions.

These provisions in the criminal enforcement section in ACTA are not likely to require Canada to modify its current treatment of criminal remedies under its copyright law regime because the list of copyright-infringing activities subject to criminal sanctions in the Copyright Act covers ACTA's requirements to criminalize wilful copyright or related rights piracy. Section 42(1) of the Copyright Act criminalizes certain intentional and commercial copyright-infringing activities, including making, selling, renting, offering for sale or rent, exhibiting in public, and importing into Canada an infringing copy of a copyrighted work or other copyrighted subject matter. ${ }^{290}$ The Copyright Act arguably exceeds ACTA's current requirements regarding the scope of criminalization in that it criminalizes the distribution of infringing copies for commercial purposes or "to such an extent as to affect prejudicially the owner of the copyright." ${ }^{291}$ In other words, the non-commercial and not-for-profit distribution of copyright-infringing works that harms the interests of rights holders is a criminal act under Canadian copyright law but is not required to be criminalized under ACTA. ACTA instead focuses on the economic or commercial effect (that is, advantage) on the infringer. Furthermore, Canadian copyright law complies with ACTA's requirement to adopt measures to "establish the liability, which may be criminal, of legal persons" for copyright piracy offences. ${ }^{292}$ Sections 42 and 43 of the Copyright Act refer to "every" or "any” person committing the offences therein, in general without differentiating between natural or legal persons. ${ }^{293}$

Throughout the ACTA negotiations, the issue of criminalizing the unauthorized recording of a movie was controversial. Negotiating countries reached a compromise by making the criminalization of this copyright-infringing activity optional rather than obligatory. ${ }^{294}$

Copyright Act, supra note 1, ss 42.1(a), (b), (d), (e). See also section 42.2, which criminalizes: (a) the possession or making of plates "designed or adapted for making infringing copies" of copyrighted works; (b) causing the unauthorized performance of a copyrighted work in public for private profit; and section 43 , another criminal remedy, which makes guilty

(1) [a]ny person who, without the written consent of the owner of the copyright or of the legal representative of the owner, knowingly performs or causes to be performed in public and for private profit the whole or any part, constituting an infringement, of any dramatic or operatic work or musical composition in which copyright subsists in Canada... (2) [a]ny person who makes or causes to be made any change in or suppression of the title, or the name of the author, of any dramatic or operatic work or musical composition in which copyright subsists in Canada, or who makes or causes to be made any change in the work or composition itself without the written consent of the author or of his legal representative, in order that the work or composition may be performed in whole or in part in public for private profit.

All the offences referred to in sections 42.1-2 and 43 require that the accused have acted "knowingly," which means that these offences require proof of the accused's mens rea, that is, "the accused's actual or subjective state of mind.” See $R v$ Laurier Office Mart Inc (1994), 58 CPR (3d) 403 (Ont Prov Ct); see also $R v$ Biron (1992), 127 NBR (2d) 142 (Prov Ct); $R v$ Harris (1990), 34 CPR (3d) 392 (Nfld Prov $\mathrm{Ct})$.

291 Copyright Act, supra note 1, s 42.1(c).

292 ACTA, supra note 2, art 23.5.

293 See also $R v$ Borge, 2005 CarswellOnt 9080 (WL Can) (Ct J), aff'd $R v$ Borge, 2007 CarswellOnt 5469 (WL Can) (Ont Sup Ct J) (where a company was charged for knowingly selling and distributing infringing copies of works in which copyright subsisted and was sentenced to a fine of $\$ 15,000$ on each count (total $\$ 75,000)$ ).

294 ACTA, supra note 2, art 23.3. Article 23.3 does not expressly limit the optional camcording provision to only wilful and commercial-scale copying. 
Regardless, this act is already criminally prohibited in Canada by virtue of section 432 of the Criminal Code, which was added in 2007. ${ }^{295}$

For the crimes and offences included in the criminal enforcement section of ACTA, the agreement requires member states to impose penalties that include imprisonment, monetary fines, ${ }^{296}$ as well as the seizure, forfeiture, and destruction of the infringing goods. ${ }^{297}$ Although ACTA does not specifically identify the making or possession of materials used to create copyright-infringing works and subject matter as a criminal offence, the agreement does include as a remedy for a criminal offence of wilful copyright piracy the seizure of related materials used in the commission of the offence and the forfeiture and destruction of materials and implements predominantly used in the creation of pirated copyright goods without compensation to the infringer. ${ }^{298}$

The Canadian Copyright Act is compliant with ACTA's obligations for criminal penalties. A person found guilty of committing any of the criminal offences under section 42 of the Copyright Act is liable "on summary conviction, to a fine not exceeding twenty-five thousand dollars or to imprisonment for a term not exceeding six months or to both,” or "on conviction on indictment, to a fine not exceeding one million dollars or to imprisonment for a term not exceeding five years or to both."299 The Copyright Act is also compliant with ACTA's obligations for criminal remedies to include seizure, forfeiture, and destruction of not only the infringing copies but the material used to create infringing copies. The Copyright Act subjects both the infringing copies and the "plates in the possession of the offender predominantly used for making infringing copies" to destruction or delivery up. . $^{300}$ Additionally, section 42(2) criminalizes knowingly making or possessing a plate specifically designed or adapted for the purposes of making infringing copies. ${ }^{301}$

One more important obligation that ACTA's criminal enforcement section imposes on its member states and with which Canada complies is the obligation to provide the competent authorities in a member state with ex officio criminal enforcement powers, enabling criminal procedures to be initiated without having to be predicated on a complaint from rights holders. ${ }^{302}$ While the officials of Canada Border Services Agency (CBSA) have no ex officio competence under copyright law with respect to investigating and prosecuting offences pertinent to copyright infringement, ${ }^{303}$ the Royal Canadian Mounted Police (RCMP), by virtue of its mandate "in relation to the preservation of the peace, the prevention of crime and of offences against the laws of Canada and the laws in force in any province," has the

Ibid, s 42.2(a). Such possession is liable on summary conviction to a fine that does not exceed $\$ 25,000$ or imprisonment for no longer than six months or both, and on conviction on indictment to a fine not exceeding one million dollars or imprisonment for a term not exceeding five years or both.

See Memorandum D19-4-3, supra note 277 at para 8: "An IPR is a private right and the actions of the CBSA in dealing with copyright or trademark-infringing goods are initiated only by a private rights holder who begins action through the courts." 
authority to investigate the offences of the Copyright Act. ${ }^{304}$ The RCMP is a competent authority within the meaning of "competent authority" in ACTA, which includes "the appropriate judicial, administrative, or law enforcement authorities under a Party’s law.”305

Although the criminal sanctions in the Copyright Act generally comply with the measures that ACTA requires its members to adopt in regard to the criminal enforcement of copyrights, Canada may not be fully compliant in one area. ACTA criminalizes aiding and abetting all of the offences mentioned in the criminal enforcement section, whereas Canada's Copyright Act does not have a general provision that covers aiding and abetting the offences described in the criminal remedies sections. ${ }^{306}$ Nevertheless, the Copyright Act criminalizes the making or possession of "any plate that is specifically designed or adapted for the purpose of making infringing copies of” any copyrighted work, which is an infringement-aiding activity. ${ }^{307}$ Moreover, the Copyright Act provides for civil liability for secondary infringement, whereby further activities (such as selling, renting, distributing, or importing) with copyrighted works or related rights material that infringe copyright, or would have infringed copyright if made in Canada, are themselves an infringement of copyright. ${ }^{308}$ Bill C-11 also newly makes it a criminal offence for any person, except those acting on behalf of a library, archive, museum, or educational institution, to knowingly circumvent a TPM for commercial purposes, to provide services to circumvent TPMs, and to traffic in anti-circumvention devices and services. ${ }^{309}$ However, ACTA's general obligation to criminalize aiding and abetting copyright infringement may require that Canada expand the scope of its current provisions.

\section{ENFORCEMENT IN THE DIGITAL ENVIRONMENT}

ACTA's digital environment enforcement section unusually covers an area for which TRIPS does not provide minimum standards. Although the WIPO Internet Treaties address the enforcement of copyright and related rights online, those treaties have not been ratified by all the ACTA negotiating countries, and the manner of implementing them has varied widely among the countries that have ratified the treaties. ACTA's provisions are both more detailed and more stringent than those in the WIPO Internet Treaties and thus will provide the most complete international standard in this area when they are in force.

The section on the enforcement in the digital environment was contentious throughout the ACTA negotiations, and the final language not only evolved considerably from the version proposed in earlier drafts but the scope was considerably narrowed. The final version

See Royal Canadian Mounted Police Act, RSC 1985, c R-10, s 18. See also Royal Canadian Mounted Police (RCMP), "Intellectual Property Rights Crime,” online: RCMP <http://www.rcmp-grc.gc.ca/feppelf/ipr-dpi/index-eng.htm>; J Anthony VanDuzer, “The Impact of the Legal Regime” in Evan H Potter, ed, Economic Intelligence \& National Security (Ottawa: Carleton University Press, 1998) 129 at 148. ACTA, supra note 2, art 5(c).

Ibid, art 23.4; Copyright Act, supra note 1, ss 42-43.

Copyright Act, ibid, s 42(2).

Ibid, ss 27(2)-(5).

Bill C-11, supra note 37, s 48, proposing s 42(3.1):

Every person, except a person who is acting on behalf of a library, archive or museum or an educational institution, is guilty of an offence who knowingly and for commercial purposes contravenes section 41.1 and is liable

(a) on conviction on indictment, to a fine not exceeding $\$ 1,000,000$ or to imprisonment for a term not exceeding five years or to both; or

(b) on summary conviction, to a fine not exceeding $\$ 25,000$ or to imprisonment for a term not exceeding six months or to both. 
requires that members ensure that the civil and criminal enforcement procedures detailed in Sections 2 and 4 of the agreement's legal framework apply to intellectual property infringement that occurs in the digital environment, including "expeditious remedies to prevent infringement" and to "constitute a deterrent to further infringements." ${ }^{\text {" }}$ Early drafts and proposals had detailed language on Internet Service Provider (ISP) liability, ${ }^{311}$ noticeand-takedown, ${ }^{312}$ secondary liability, ${ }^{313}$ and three-strike provisions. ${ }^{314}$ These controversial provisions, which were heavily criticized by observers during the negotiations and attracted a great deal of commentary, ${ }^{315}$ were not included in the final agreement. It is also notable that

ACTA, supra note 2, art 27.1.

ACTA: July 2010 Leaked Draft, supra note 51 ch 2, s 4, art 2.18(3).

ACTA omitted including a duplicate of the safe harbour system found in the US Digital Millenium Copyright Act, 112 Stat 2860 (1998), with its “notice-and-take-down” component. Under the US regime, upon receiving a notice from rights holders, ISPs are required to remove or block access to the allegedly infringing content available on their systems or networks in order to benefit from the liability immunity provided in the safe harbor provisions; see 17 USC § 512(c); see also ACTA: July 2010 Leaked Draft, supra note 51, ch 2, s 4, art 2.18(3); ACTA: April 2010 Consolidated Text, supra note 14, ch 2, s 4, art 2.18(3). This would have required Canada to give up its "notice-and-notice" regime, in which ISPs merely forward the notifications of infringement allegations received from copyright holders to the relevant subscribers who are allegedly infringing copyrights through the ISPs' networks, rather than taking the content down. For the details of the mechanism of this system, see Canadian Association of Internet Providers (CAIP), “Code of Conduct,” principles 5-7, online: CAIP <http://www.cata.ca/ Communities/caip/codeofconduct/CodeConduct.html>; Sheryl N Hamilton, "Made in Canada: A Unique Approach to Internet Service Provider Liability and Copyright Infringement" in Michael Geist, ed, In The Public Interest: The Future of Canadian Copyright Law (Toronto: Irwin Law, 2005) 285 at 295-96; see also CAIP, "Submission re Paper on Digital Copyright Issues," (18 September 2001), online: Government of Canada <http:/www.ic.gc.ca/eic/site/crp-prda.nsf/eng/rp00314.html> (stating that a notice-and-take-down system contradicts the "fundamental principle of Canadian law that someone is innocent until proven guilty" and suggesting the codification of the voluntary notice-and-notice regime). ACTA: July 2010 Leaked Draft, supra note 51, ch 2, s 4, art 2.18(3); ACTA: April 2010 Consolidated Text, supra note 14, ch 2, s 4, art 2.18(3). The final version abandons the provisions that would have required Canada to adopt a US-style secondary liability system, under which an individual may be held liable for a copyright infringement committed by someone else, on the grounds of contributory infringement, inducement, or vicarious liability. By contrast to the situation in the US, which distinguishes vicarious and contributory infringement and recognizes that someone who does not directly infringe copyright may nevertheless infringe by contributing or encouraging infringement, Canadian copyright law has the single concept of secondary infringement in sections 27(2)-(5) of the Copyright Act, supra note 1 , which does not expressly include mere contribution to infringement and does not include inducement-based infringement. Canadian copyright law has a right to "authorize," which is included as one of the copyright owners' economic rights in section 3(1) of the Copyright Act, ibid, s 3(1). Under Canadian law, the statutory right to authorize the performance of an economic right is an autonomous right that is separate from the performance of those rights ( $C C H$, supra note 148 at para 37). Infringement of the authorization right is a primary type of infringement rather than secondary, and has a different meaning than the meanings afforded to it in other jurisdictions (Copyright Act, supra note 1, ss 3(1), 27; CCH, ibid at para 37: "Under s. 27(1) of the Copyright Act, it is an infringement of copyright for anyone to do anything that the Act only allows owners to do, including authorizing the exercise of his or her own rights.”) In $C C H$, ibid at para 38, the Supreme Court of Canada held that "[c]ountenance in the context of authorizing copyright infringement must be understood in its strongest dictionary meaning, namely, '[g]ive approval to; sanction, permit; favour, encourage.’” For a general comparison of American copyright law on secondary liability and Canadian copyright law, see generally Roderick G Dorman \& Howard P Knopf, Brief of Amicus Curiae Sharman Networks Limited in Support of Respondents in Metro-Goldwyn-Mayer Studios, Inc v Grokster Ltd, 380 F (3d) 1154 (9th Cir 2004), online: US Copyright Office <http://www.copyright.gov/docs/mgm/sharman-networks.pdf >; Jeremy de Beer, "Legal Strategies to Profit from Peer Production” (2008) 46 Can Bus LJ 269 at 272-75; Barry Sookman \& Eric J Schwartz, "Copyright Law in Canada and the United States: The Digital Challenge" (2009) 11 One Issue, Two Voices 1 at 29, online: Woodrow Wilson International Center for Scholars <http://www.wilsoncenter.org/topics/pubs/Copyright\%20final.pdf >.

These provisions cut off an alleged infringer's access to internet services. See European Union's Comments to the US Proposal: Special Requirements Related to the Enforcement of Intellectual Property Rights in the Digital Environment (29 October 2009), online: Digitale Linke <http://blog.dielinke.de/digitalelinke/wp-content/uploads/674b-09.pdf>.

See Canadian Library Association, "Brief to Foreign Affairs and International Trade Canada on the Anti-Counterfeiting Trade Agreement” (30 April 2008), online: DFAIT < http://www.international.gc.ca/ trade-agreements-accords-commerciaux/assets/pdfs/CLASubmissionanticounterfeiting080430.pdf> (criticizing the impact of the notice-and-takedown regime on free speech and urging the Canadian negotiators to reject its inclusion in ACTA); Weatherall, "ACTA: Australian Section by Section 
the digital enforcement section makes reference to rights and interests other than intellectual property rights more explicitly than is commonly seen in ACTA's other sections. ACTA, as noted, sets out general obligations in Article 6, such as the proportionality principle, which apply to the whole legal framework. ${ }^{316}$ In the civil and criminal enforcement sections, the protections in Article 6 tend not to be repeated or contextualized for those particular sections, which distinguishes ACTA from the style of drafting in TRIPS, where the individual articles often contain specific safeguards. ${ }^{317}$ By contrast to ACTA's civil and criminal enforcement sections, in ACTA's digital enforcement section there are several specific references to rights other than those belonging to the rights holder, including safeguards and rights that would be important for users of intellectual property. For example, Articles 27.2, 27.3, and 27.4 each speak of preserving "fundamental principles such as freedom of expression, fair process, and privacy." ${ }^{118}$ The agreement also states that enforcement procedures against copyright infringement on digital networks, including against the "unlawful use of means of widespread distribution for infringing purposes," shall be implemented to avoid creating barriers to legitimate activity, including electronic commerce, and, as an example, a note expressly permits members to adopt or maintain laws limiting ISP liability. ${ }^{319}$ Further, Article 27.8 expressly states that the obligations to protect TPMs and RMI are "without prejudice to the rights, limitations, exceptions, or defences to copyright or related rights infringement under a Party's law," and that members may "adopt or maintain appropriate limitations or exceptions" to the implementing measures. ${ }^{320}$ Indeed, this emphasis is highlighted as early as the Preamble's admonition that the problem of infringement of intellectual property rights, "including infringement taking place in the digital environment, in particular with respect to copyright or related rights," be addressed "in a manner that balances the rights and interests of the relevant right-holders, service providers, and users.”321 Accordingly, member states enjoy a fair amount of flexibility to determine the manner of applying the digital enforcement provisions in light of national laws and citizens' essential rights and freedoms.

Analysis," supra note 140 at 50-51 (arguing that the secondary liability provisions of ACTA should be rejected because they provide rights holders with new substantive rights while ACTA is supposed to be merely an enforcement agreement); European Parliament, "Resolution of 10 March 2010," supra note 48 (stating that the European Parliament "[c]onsiders that in order to respect fundamental rights, such as the right to freedom of expression and the right to privacy, while fully observing the principle of subsidiarity, the proposed agreement should not make it possible for any so-called 'three-strikes' procedures to be imposed" (ibid at L(11)). See also Frank La Rue, Report of the Special Rapporteur on the promotion and protection of the right to freedom of opinion and expression, UN Human Rights Counsel, 17th Sess, Agenda Item 3, UN Doc A/HRC/17/27 (2011) at paras 49-50, online: Office of the High Commissioner for Human Rights <http://www2.ohchr.org/english/bodies/hrcouncil/docs/17 session/A.HRC.17.27_en.pdf > (stating that the Special Rapporteur "is alarmed by proposals [such as three-strike legislation] to disconnect users from Internet access if they violate intellectual property rights" and that, although the three-strike proposal was finally dropped from ACTA, he "remains watchful about the treaty's eventual implications for intermediary liability and the right to freedom of expression”).

$316 \quad$ Supra note 2, art 6.

317 Commission Services Working Paper, supra note 73 at 8:

This general requirement [proportionality principle] applies to all parts of ACTA, a fortiori to all sections under Chapter II of ACTA on the 'legal framework for enforcement of IPRs.' During the negotiations, it was agreed among the Parties that making additional references to the proportionality principle in other provisions of ACTA was not only unnecessary but could also raise questions as to the applicability of the general requirement whenever a specific reference was lacking.

ACTA, supra note 2, art 27.

Ibid, art 27.2 and $\mathrm{n} 13$. Article 27.4, which is a permissive provision for a right to information about subscribers from ISPs, has a similar reference to avoiding the creation of barriers against legitimate activity, including electronic commerce.

Ibid, art 27.8.

Ibid, Preamble, para 6. 
As a result of ACTA's final text omitting or diluting several provisions in the digital enforcement section over the course of the negotiations, including ones that were particularly contentious, the more extensive changes that would have been required in Canadian copyright law are no longer necessary. In the final version, the general civil enforcement procedures on provisional measures and injunctions apply in lieu of the omitted mechanism for take-down notices, ${ }^{322}$ there are no provisions on third-party secondary liability, members are permitted to retain their laws limiting ISP liability, ${ }^{323}$ and, rather than three-strikes provisions, there is only a permissive provision enabling rights holders to obtain information from intermediaries about subscribers. ${ }^{324}$ The final text of ACTA's section on enforcement in the digital environment still requires members to address infringements of copyright or related rights through the use of "means of widespread distribution," such as peer-to-peer (P2P) file-sharing systems, and to protect TPMs and RMI against circumvention. ${ }^{325}$ With the passage of Bill C-11, Canada generally meets and, in some aspects, surpasses these obligations, with a few possible caveats highlighted below.

\section{DigITAL ENVIRONMENT INFRINGEMENTS AND THE UNLAWFUL USE OF P2P FILE-SHARING SYSTEMS}

The section defining the scope of enforcement that member states are obliged to provide in the digital environment states that ACTA's civil and criminal enforcement measures must be available against any "act of infringement of intellectual property rights which takes place in the digital environment." ${ }^{326}$ These remedies also need to be applied to copyright or related rights infringements taking place over "digital networks," which "may include” the unlawful use of technologies capable of facilitating "widespread distribution" of copyright- or relatedrights infringing materials, such as $\mathrm{P} 2 \mathrm{P}$ file-sharing systems. ${ }^{327}$ ACTA provides, however, that the procedures shall be implemented in a way that avoids creating barriers to legitimate activity, such as electronic commerce, and to preserve "fundamental principles such as freedom of expression, fair process, and privacy."328

File sharing of musical works is the most conspicuous example of online conduct that generates complaints by copyright holders in Canada, ${ }^{329}$ but not all such activities constitute

$322 \quad$ Ibid, art 27.1.

$323 \quad$ Ibid, art 27.2, n 13.

$324 \quad$ Ibid, art 27.4:

A Party may provide, in accordance with its laws and regulations, its competent authorities with the authority to order an online service provider to disclose expeditiously to a right holder information sufficient to identify a subscriber whose account was allegedly used for infringement, where that right holder has filed a legally sufficient claim of trademark or copyright or related rights infringement, and where such information is being sought for the purpose of protecting or enforcing those rights.

$325 \quad$ Ibid, art 27.

$326 \quad$ Ibid, art 27.1.

$327 \quad$ Ibid, art 27.2 .

328 Ibid.

329 See e.g. Canadian Recording Industry Association (CRIA), "Facts about File Sharing” (2006), online: CRIA < http://web.archive.org/web/20110706174619/http://cria.ca/filesharing.php> (outlining the losses that the music industry has suffered in Canada due to file sharing); CRIA, Press Release, "Canada's Music Sales Fall 35\% in First Quarter” (26 April 2007), online: CNW <http://www.newswire.ca/fr/ story/5453/canada-s-music-sales-fall-35-in-first-quarter>; “Canadian Music Industry Groups Call on Government to Make Anti-Piracy Measures a Priority in Upcoming Throne Speech” (25 September 2007), online: CNW Newswire <http://www.newswire.ca/en/releases/archive/September2007/25/c4634. html>; CRIA, Press Release, "Legal downloading on the rise in Canada, but fileswapping still a problem” (19 January 2005), online: Canadian Independent Music Association (CIMA) <http:// 
copyright infringement under Canadian law. First, the Copyright Act has a private copying regime in sections 79-88, which renders certain otherwise infringing acts non-infringing and remunerates rights holders through a levy on specified recordable media. ${ }^{330}$ Under that regime, reproducing a musical work or performer's performance embodied in a sound recording onto an "audio recording medium" for the "private use of the person who makes the copy" does not infringe the copyright in the musical work, the performance, or the sound recording. ${ }^{331}$ Instead, the Copyright Act entitles the rights holders of musical works to receive remuneration in the form of a levy from the "manufacturers and importers of blank audio recording media.”332 An umbrella collective society distributes the levies to rights holders as compensation for uses of copyrighted works and related rights subject matter that have been rendered non-infringing by the private copying regime. ${ }^{333}$ Several conditions must be satisfied for the regime to apply: the recording must be music, and it must be recorded on an audio recording medium for private use. ${ }^{344}$ Currently, these media include recordable compact discs (CD-R, CD-RW, CD-R Audio, CD-RW Audio), and MiniDiscs, but not DVDs. ${ }^{335}$ Moreover, certain purposes are excluded from the regime, including selling, renting, distributing, communicating to the public by telecommunication, and performing (and hence reproducing music for these purposes is infringing unless another exception applies). ${ }^{336}$ Notably, even non-commercial distribution (“distributing, whether or not for the purpose of trade”) is excluded from the protection of the regime. ${ }^{337}$

www.cirpa.ca/Page.asp?PageID=122\&ContentID=717>. Rights holders have cited studies and reports on the number of P2P downloads in Canada and the impact of this activity on the decline of music sales in the country. See e.g. Organization for Economic Co-operation and Development (OECD), "Digital Broadband Content: Music” (13 December 2005) at 75, online: OECD <http://www.oecd.org/dataoecd/ 13/2/34995041.pdf> (stating: "Weighted by population ... Canada has the greatest file-sharing population closely followed by the United States and then France and Germany”); International Federation of the Phonographic Industry (IFPI), Recording Industry in Numbers 2010 (28 April 2010), online: IFPI <http://www.ifpi.org/content/section_news/20100428.html> (attributing the decline of music sales in Canada to its ineffective anti-piracy regime). But see Bart Cammaerts \& Bingchun Meng, "Creative Destruction and Copyright Protection: Regulatory Responses to File-sharing" (21 March 2011), online: LSE Media Policy Project < http://blogs.lse.ac.uk/mediapolicyproject/2011/03/21/mediapolicy-project-policy-brief-1-creative-destruction-and-copyright-protection/ $>$ (concluding that “[d]ecline in the sales of physical copies of recorded music cannot be attributed solely to file-sharing, but should be explained by a combination of factors such as changing patterns in music consumption, decreasing disposable household incomes for leisure products and increasing sales of digital content through online platforms”); Birgitte Andersen \& Marion Frenz, “The Impact of Music Downloads and P2P File-Sharing on the Purchase of Music: A Study for Industry Canada” (November 2007), online: Industry Canada <http://www.ic.gc.ca/eic/site/ippd-dppi.nsf/vwapj/IndustryCanadaPaperMay4_2007_en.pdf/\$FILE/ IndustryCanadaPaperMay4_2007_en.pdf> (in which the authors were "unable to discover any direct relationship between P2P file-sharing and CD purchases in Canada" and found a correlation whereby "P2P file-sharing tends to increase rather than decrease music purchasing") (ibid at 26, 3). See also Daniel Gervais, "User-Generated Content and Music File-Sharing: A Look at Some of the More Interesting Aspects of Bill C-32" in Michael Geist, ed, From "Radical Extremism” to "Balanced Copyright”: Canadian Copyright and the Digital Agenda (Toronto: Irwin Law, 2010) 447 at 454-57 (discussing the impact of P2P on music sales). Copyright Act, supra note 1, ss 79-88.

Ibid, s 80(1). Section 79 defines "audio recording medium” as "a recording medium, regardless of its material form, onto which a sound recording may be reproduced and that is of a kind ordinarily used by individual consumers for that purpose, excluding any prescribed kind of recording medium."

Ibid, s 81 (right of remuneration). "Blank audio recording medium” is defined in section 79 as “(a) an audio recording medium onto which no sounds have ever been fixed, and (b) any other prescribed audio recording medium.”

Copyright Act, supra note 1, s 84.

Ibid, s 80.

Private Copying Tariff, 2010, (2010) C Gaz I (Supp) (Copyright Act), online: Canada Gazette <http:// www.gazette.gc.ca/rp-pr/p1/2010/2010-05-29/html/sup-eng.html\#REF1>.

Copyright Act, supra note 1, ss 80(2)(a)-(d).

Ibid, s 80(2)(b). 
By virtue of the operation of the private copying regime, downloading and uploading have distinct legal implications in Canada. Downloading a musical work for personal use by any means, including P2P file-sharing services, onto any of the designated media in the private copying regime does not constitute copyright infringement providing the requirements of the regime are met. ${ }^{338}$ On the other hand, the unauthorized download of a musical work onto a recording medium that does not satisfy the statutory definition of "audio recording medium"339 — such as computer hard drives, flash memories, portable media players (such as MP3 players and iPods) and their memories, DVDs, and removable hard drives - does not qualify as private copying and can be an infringement under sections 3, 15, 18(1)(b), and 27(1) of the Copyright Act. Further, the download cannot be for the purpose of selling or renting out, distributing, communicating to the public by telecommunication, or performing the work. ${ }^{340}$ Additionally, because the private copyright regime applies only where the copying involves a musical work and is for personal use, the unauthorized downloading of any other copyrighted work, such as movies or digital books, would constitute copyright infringement, unless one of the copyright infringement exceptions, such as fair dealing, applies.

By contrast, unlike downloading, which may be covered by the private copying regime, uploading a musical work to a shared directory on a P2P file-sharing system and making it available for others to download is outside the scope of the private copying regime if it constitutes a form of telecommunication to the public or distribution (which are exempted from the regime). ${ }^{341}$ Although the Copyright Act does not have a "making available right," infringement could be based first, on authorizing one of the copyright owner's section 3 rights without the copyright owner's permission; ${ }^{342}$ second, on unauthorized communicating of these works to the public by telecommunication or authorizing such communication; ${ }^{343}$ or

See the Copyright Act, ibid, s 80:

(1) Subject to subsection (2), the act of reproducing all or any substantial part of

(a) a musical work embodied in a sound recording,

(b) a performer's performance of a musical work embodied in a sound recording, or

(c) a sound recording in which a musical work, or a performer's performance of a musical work, is embodied

onto an audio recording medium for the private use of the person who makes the copy does not constitute an infringement of the copyright in the musical work, the performer's performance or the sound recording.

(2) Subsection (1) does not apply if the act described in that subsection is done for the purpose of doing any of the following in relation to any of the things referred to in paragraphs $(1)(a)$ to $(c)$ :

(a) selling or renting out, or by way of trade exposing or offering for sale or rental;

(b) distributing, whether or not for the purpose of trade;

(c) communicating to the public by telecommunication; or

(d) performing, or causing to be performed, in public.

See Canadian Private Copying Collective v Canadian Storage Media Alliance, 2004 FCA 424, [2005] 2 FC 654 [CPCC v CSMA] (holding at para 133 that the Copyright Board was not entitled to establish a levy on a "permanently embedded or non-removable memory, incorporated into a digital audio recorder (MP3 player)” or on the digital audio recorder devices); Apple Canada Inc v Canadian Private Copying Collective, 2008 FCA 9 [Cdn Private Copying], rev'g Private Copying 2008-2009, Re, 58 CPR (4th) 446 (Copyright Bd) (overruling the Copyright Board's decision to certify a levy on portable media recorders, such as iPod and MP3 players, and holding at para 3 that CPCC $v$ CSMA is "authority for the proposition that the Copyright Board has no legal authority to certify a tariff on digital audio recorders or on the memory permanently embedded in digital audio recorders"). The Copyright Board had excluded DVDs and removable hard drives as well as removable electronic memory cards from the levy. This part of the Board's decision was not appealed to the Federal Court of Appeal.

See Copyright Act, supra note 1, s 80(2).

Ibid, s $80(2)$.

Ibid, ss 3, 27(1); SOCAN, supra note 148.

Copyright Act, ibid, ss 3(1)(f), 3(1), 27(1). 
third, for secondary infringement, on distributing unauthorized copies of the work to an extent that prejudicially affects the copyright holder. ${ }^{344}$

First, individuals uploading musical works to shared directories accessible by P2P filesharing services might be found liable for infringing the section 3(1) right to authorize. For example, if the download would infringe another economic right (such as reproduction or communication to the public), ${ }^{345}$ then the P2P user who made the file available would infringe the right to authorize, providing that there is no relevant exception such as fair dealing, and that the private copying regime does not apply. However, infringement by authorizing the reproduction of the copyrighted works would not be established in situations where the "unauthorised reproduction" (download) is exempted from copyright infringement by virtue of the private copying exception in section 80 of the Copyright Act. Conversely, if the individual downloading the musical work is not exempted from liability by virtue of the private copying regime, the individual placing the musical work on a shared directory accessible by means of P2P file-sharing systems is authorizing the illegal reproduction of the copyrighted work, and is therefore liable, unless another exception, such as fair dealing, is applicable to the download. For example, since a download of a musical file to a hard drive of a computer would not qualify under the private copying exception, an individual uploading the musical file on a shared directory is considered to be authorizing the infringing reproduction of this file on the hard drive of the individual downloading the file. This means that, to some extent, P2P file sharers are linked in a chain of copyright liability dependence.

Second, an individual uploading a copyrighted work to a shared directory accessible to others by means of P2P file sharing could be found liable for infringing the copyright in the work by communicating it to the public by telecommunication. ${ }^{346}$ To establish copyright infringement in this case, the file-sharing peers must be found to constitute a "public," to satisfy the first requirement for finding infringement under section 3(1)(f), which requires a communication "to the public by telecommunication." 347 The definition of "public" under the North American Free Trade Agreement, however, likely encompasses individuals downloading music by means of file sharing. ${ }^{348}$ More importantly, the Supreme Court of Canada in $\mathrm{CCH}$ held that, while a "fax transmission of a single copy to a single individual is not a communication to the public ... a series of repeated fax transmissions of the same work to numerous different recipients might constitute communication to the public in infringement of copyright." ${ }^{349}$ More closely analogous, the Federal Court of Appeal has ruled

$344 \quad$ Ibid, s 27(2)(b).

$345 \quad$ Ibid, ss 3, 3(1)(f).

$346 \quad$ Ibid, s 3(1)(f).

347 See Judge \& Gervais, supra note 202 at 185-86; Copyright Act, ibid, s 3(1)(f).

348 North American Free Trade Agreement Between the Government of Canada, the Government of Mexico and the Government of the United States, 17 December 1992, Can TS 1994 No 2, 32 ILM 289, (entered into force 1 January 1994), art 1721:

public includes, with respect to rights of communication and performance of works provided for under Articles 11, 11bis(1) and 14(1)(ii) of the Berne Convention, with respect to dramatic, dramatico-musical, musical and cinematographic works, at least, any aggregation of individuals intended to be the object of, and capable of perceiving, communications or performances of works, regardless of whether they can do so at the same or different times or in the same or different places, provided that such an aggregation is larger than a family and its immediate circle of acquaintances or is not a group comprising a limited number of individuals having similarly close ties that has not been formed for the principal purpose of receiving such performances and communications of works. 
that a wireless carrier's transmission of a ringtone to the handsets of individual customers is a communication "to the public" because it is a series of transmissions of the same musical

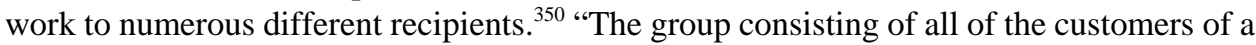
wireless carrier is a group that is sufficiently large and diverse that it may fairly be characterized as 'the public." "351 As the Federal Court of Appeal reasoned, “[i]f a wireless carrier were to transmit a particular ringtone simultaneously to all customers who have requested it, that transmission would be a communication to the public. It would be illogical to reach a different result simply because the transmissions are done one by one, and thus at different times."352 Accordingly, recipients of musical works through P2P file-sharing services might well qualify as a "public" within the meaning of section 3(1)(f) of the Copyright Act.

As to the requirements of a "communication" and "telecommunication," the Federal Court of Appeal also concluded that, even though the cellphone owner cannot listen to the music during the transmission, the wireless transmission of the digital audio file of a ringtone is a "communication" when the transmission is complete even if the subscriber does not listen to the music until later. ${ }^{353}$ Similarly important, the Supreme Court of Canada held in SOCAN that "[i]f the communication is by virtue of the Internet, there has been a "telecommunication." "354 Thus, when the music is transmitted to the recipient, the requirements for section 3(1)(f) of the Copyright Act (for "public," "communication,” and "telecommunication") are satisfied for the liability of individuals placing musical works on shared computer directories accessible by P2P file-sharing systems. Further, as noted above, the individual may also be liable for authorizing the section 3(1)(f) right to communicate the musical work to the public by telecommunication.

Third, placing a musical work on a shared directory for downloads by P2P file sharing may constitute secondary infringement under section 27(2)(b) of the Copyright Act. Providing services that enable file sharing, however, is unlikely to constitute copyright infringement under Canadian copyright law. The Copyright Act does not have vicarious or contributory infringement, and there is no requirement in ACTA's final text that a member country impose such liability. Further, providing technologies or tools by which infringement takes place, without more, does not breach the section 3(1) authorization right. ${ }^{355}$ In $\mathrm{CCH}$, the Supreme Court held that "a person does not authorize copyright infringement by authorizing the mere use of equipment (such as photocopiers) that could be used to infringe copyright. In fact, courts should presume that a person who authorizes an activity does so

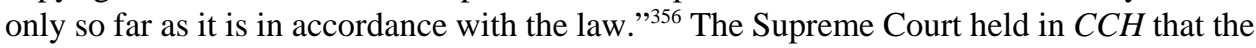
Law Society of Upper Canada did not have enough control over the users of the library to

Canadian Wireless Telecommunications Association v Society of Composers, Authors \& Music Publishers of Canada, 2008 FCA 6, [2008] 3 FCR 539 [Canadian Wireless Telecommunications Assn], aff'g Public Performance of Musical Works, Re, [Tariff No 24 -Ringtones (2003-2005)], [2006] 52 CPR (4th) 375 (Copyright Board), online: Copyright Board <http://www.cb-cda.gc.ca/decisions/2006/ 20060818-m-f.pdf>.

Canadian Wireless Telecommunications Assn, ibid at para 32.

Ibid at para 43.

Ibid at para 19.

SOCAN, supra note 148 at para 45.

Copyright Act, supra note 1, s 3(1).

$\mathrm{CCH}$, supra note 148 at para 43 (holding at para 42 that a library providing photocopying services to its users does not "constitute authorization to use the photocopiers to breach copyright law"). 
have "sanctioned, approved or countenanced the infringement" for purposes of the section 3(1) authorization right. ${ }^{357}$ Subsequently, in SOCAN, the Supreme Court concluded that ISPs were not liable to pay a tariff to a collective society when musical works in the collective's repertoire were communicated over the internet and found, in part, that ISPs were not "authorizing" copyright infringement. ${ }^{358}$ The Supreme Court held that "when massive amounts of non-copyrighted material are accessible to the end user, it is not possible to impute to the Internet Service Provider, based solely on the provision of Internet facilities, an authority to download copyrighted material as opposed to non-copyrighted material."359 The Court, following the reasoning in $\mathrm{CCH},{ }^{360}$ held that the "knowledge that someone might be using neutral technology to violate copyright ... is not necessarily sufficient to constitute authorization" of copyright infringement and reiterated that to find authorization, the defendants must “' [g]ive approval to, sanction, permit, favour, [or] encourage’ the infringing conduct."361

Answering whether Canadian copyright law complies with ACTA's compulsory provision requiring effective enforcement of copyrights and related rights in the digital environment is a demanding inquiry given the various legal dimensions of file sharing under Canadian copyright law. One controversial aspect is likely to be whether the Canadian private copying regime complies with ACTA given that, subject to the conditions described in the statute, the regime allows some activities pertaining to music file sharing that would otherwise be infringing. ${ }^{362}$ One avenue of justification for the private copying regime is to reference the several public interest safeguards in ACTA's digital enforcement section; namely, that ACTA requires that the implementation of the digital enforcement procedures be consistent with the member state's law; that they be respectful of individuals' fundamental freedoms, such as privacy, fair process, and free expression; and that they avoid creating barriers to legitimate activities, such as electronic commerce. ${ }^{363}$

To clarify the ambiguity regarding Canada's compliance with ACTA's obligation to prohibit the unlawful use of "means of widespread distribution" for copyright-infringing purposes, the Copyright Act could be amended to establish liability for enabling illegal filesharing activities. Although neither Bill C-60 nor Bill C-61 addressed this reform, Bill C-11 makes it an infringement of copyright to provide services that could enable copyright infringement in the digital environment. ${ }^{364}$ Importantly, Bill C-11 includes a number of conditions to mitigate the enablement prohibition's potential chilling effect on providers of legitimate digital sharing services, ${ }^{365}$ but any prospective reform to the Copyright Act could treat these as a minimum and provide additional protections. According to Bill C-11, in order to find someone liable for enabling the infringement of copyright, the enabling service must be "designed primarily" to enable copyright-infringing activities, the person providing the service must know or should have known that the service was “designed primarily” to enable

\footnotetext{
Ibid at para 45.

SOCAN, supra note 148.

Ibid at para 123.

CCH, supra note 148

SOCAN, supra note 148 at para 127 [emphasis in original], quoting $C C H$, supra note 148 at para 38.

The private copying regime is Copyright Act, supra note 1, ss 79-88.

ACTA, supra note 2, art 27.2.

Bill C-11, supra note 37, s 18, proposing s 27(2.3).

Ibid, s 18, proposing s 27(2.3)-(2.4).
} 
copyright-infringing activities, and the use of the service resulted in actual copyright infringement. ${ }^{366}$ This approach is consistent with the distinctive notion of "authorizing" copyright infringement under Canadian copyright law. ${ }^{367}$

\section{ISP LIABILITY, COOPERATION ENDEAVOURS, AND INFORMATION RELEASE}

In a remarkable retreat from its early drafts, ACTA does not require the regulation of ISP liability. The only time ISP liability is mentioned is when a safe harbour system that limits ISP liability from copyright infringements taking place through their services is provided in a footnote as an example of the measures that could be taken to preserve individuals' freedoms and maintain the flow of legitimate trade while enforcing intellectual property rights online. ${ }^{368}$ ACTA has also replaced the previously proposed compulsory regulation of third-party liability for copyright infringement with a general provision obliging member states "to promote cooperative efforts within the business community to effectively address" infringements in the digital environment. ${ }^{369}$ The flexibility of these provisions saves Canada from applying radical changes to its current treatment of ISP liability and enables Canada to retain its notice-and-notice regime.

The Canadian Copyright Act does not contain a comprehensive treatment of ISP liability, although the Supreme Court of Canada has held that section 2.4(1)(b), the provision exempting passive conduits from infringing the section 3(1)(f) right to communicate to the public by telecommunication, applies to ISPs when they act purely as a "conduit" for communication to the public and do not "engage in acts that relate to the content of the communication." ${ }^{370}$ In its application of that provision to ISPs, the Supreme Court of Canada concluded that "the Copyright Act, as a matter of legislative policy established by Parliament, does not impose liability for infringement on intermediaries who supply software and hardware to facilitate use of the Internet." 371 The Court held that "a lack of actual knowledge of the infringing contents, and the impracticality (both technical and economic) of monitoring the vast amount of material moving through the Internet, which is prodigious," are distinguishing qualities of an ISP having the status of a "conduit." "772 To benefit from section 2.4(1)(b), the means which the ISP provides must be "necessary": the Supreme Court explained that "[i]n context, the word 'necessary' in s. $2.4(1)(b)$ is satisfied if the means are reasonably useful and proper to achieve the benefits of enhanced economy and efficiency." 373 The Supreme Court in SOCAN also addressed the practice of ISP caching and held that it

Ibid, s 18, proposing s 27(2.3).

See supra note 313 , for a discussion on authorizing copyright infringement under Canadian copyright law.

ACTA, supra note 2, art 27.2, n 13.

Ibid, art 27.3.

SOCAN, supra note 148 at para 92; see also ibid at paras 102, 104. Section 2.4(1)(b) of the Copyright Act, supra note 1 provides: "a person whose only act in respect of the communication of a work or other subject-matter to the public consists of providing the means of telecommunication necessary for another person to so communicate the work or other subject-matter does not communicate that work or other subject-matter to the public.” SOCAN, ibid at para 101.

Ibid.

Ibid at para 91. 
should not attract copyright liability when undertaken only to provide a faster and more efficient service. ${ }^{374}$

ACTA's early drafts had described a notice-and-takedown system (in which ISPs must take down material after being notified of copyright infringement by a right holder) as part of the ISP liability provision, although the requirement was deleted from the final version of the agreement. ${ }^{375}$ Canadian law does not oblige ISPs to follow such a system, and, except for court orders, ISPs' current Canadian practice with respect to allegations of copyright infringement by their subscribers instead follows a voluntary commitment to a "notice-andnotice system.” ${ }^{\text {"76 }}$ The current Canadian notice-and-notice system can be characterized as a practical application of the cooperation that ACTA asks its member states to promote within the business community to address infringements in the digital environment. ${ }^{377}$ Notwithstanding the voluntary notice-and-notice practice, in Canada the identities of internet subscribers who are allegedly infringing copyright are released only through a court order. ${ }^{378}$ Respecting individuals' privacy rights in this context complies with ACTA, first, because the agreement makes it optional whether member states give authorities the power to order ISPs to disclose the identities of allegedly infringing subscribers to the rights holders, and second, because the agreement mandates that such procedures if implemented shall be in a manner that preserves fundamental principles including privacy. ${ }^{379}$

Ibid at paras 115-16.

In SOCAN, ibid at para 127, the Supreme Court of Canada hinted that a "notice of infringing content, and a failure to respond by 'taking it down' may in some circumstances lead to a finding of 'authorization,'” and suggested that a solution to this issue may lie in legislation that includes a "notice and take down" system.

See Gregory R Hagen, “"Modernizing’ ISP Copyright Liability,” in Michael Geist, ed, From "Radical Extremism" to "Balanced Copyright": Canadian Copyright and the Digital Agenda (Toronto: Irwin Law, 2010) 361 (distinguishing Canada’s notice-and-notice system from notice-and-takedown and graduated response systems). As described in Hamilton, supra note 312 at 296, under this notice-andnotice system, rights holders can send a notice to the ISP complaining that specific ISP subscribers are infringing. Subsequently, the ISP forwards this notice to the relevant subscribers advising them that they are abusing the ISP's services by engaging in allegedly copyright-infringing activities. The ISP informs the subscribers of the details of the rights holders' allegations, and advises them to contact the complaining rights holders. Finally, the ISP sends a notice to the rights holders indicating that the ISP has passed their notice to the relevant subscriber. The role of the ISP ends here; if the relevant subscriber does not comply with the notice and refrain from infringing copyright, the rights holders would need to pursue their options against the alleged infringers through the available means under copyright law. The ISPs have observed that a sizable amount of alleged infringing content is removed voluntarily by customers receiving these notices, though it is difficult to infer from these responses whether the content was indeed infringing or whether the notices at least sometimes have a chilling effect on legitimate uses of copyrighted material. See Michael Geist, "The Effectiveness of Notice and Notice" (15 February 2007), online: Michael Geist <http://www.michaelgeist.ca/content/view/1705/125/>. According to the former President of the Canadian Association of Internet Providers, Jay Thomson, the "notice and notice" system is "already highly successful ... resolving $80-90 \%$ of the infringement complaints received.” Jay Thomson, Oral Remarks of the Canadian Association of Internet Providers (CAIP), Standing Committee on Canadian Heritage Review of the Canadian Copyright Act (4 November 2003), online: Canadian Advanced Technology Alliance <http://www.cata.ca/files/PDF/caip/copyright/03November-04HertitageCommittee.pdf>. Rogers, Bell, and Telus, the three major Canadian ISPs, were supportive of codifying the "notice and notice" system in the hearings on Bill C-32, and thus would support the identical system in Bill C-11. See House of Commons, Legislative Committee on Bill C-32, 40th Parl, 3d Sess, (22 March 2011), online: House of Commons <http://www2.parl.gc.ca/House Publications $/$ Publication . aspx ? DocId $=5057232 \&$ Language $=E \&$ Mode $=1 \&$ Parl $=40 \&$ Ses $=3 \#$ Int 3816405>.

ACTA: October 2010 Consolidated Text, supra note 53, ch 2, s 5, art 2.18(3).

See BMG Canada Inc v John Doe (FC), 2004 FC 488, [2004] 3 FCR 241, aff'd BMG Canada Inc v John Doe, 2005 FCA 193.

ACTA, supra note 2, art 27.4. The rights holders must have "filed a legally sufficient claim of infringement" and must seek the information for the "purpose of protecting or enforcing" the allegedly infringed rights. 
Although the provisions respecting ISP liability are removed from ACTA's final text, it should be noted that ISP liability is an active issue in Canada's ongoing copyright reform process. The amendments in Bill C-11 (as in Bill C-60, Bill C-61, and Bill C-32 before it) clarify ISP liability. ${ }^{380}$ Bill C-11 exempts ISPs when they are acting as pure intermediaries with respect to their communication, ${ }^{381}$ when they practice caching for technical reasons, ${ }^{382}$ and when they host content. ${ }^{383}$ Further, Bill C-11 codifies the Canadian notice-and-notice system to deal with online infringement activities. ${ }^{384}$ According to the Bill, although an ISP is not required to remove the allegedly infringing content, it is required to retain the relevant subscriber's information for six months, or for one year if the matter is litigated. ${ }^{385}$

\section{The PROTECTION OF TPMS AND RMI}

The section on enforcement in the digital environment provides protection for TPMs and RMI, which adds substantive rights to the bundle of rights that copyright holders already enjoy under traditional copyright law. Article 27.5 requires member states to provide

\footnotetext{
adequate legal protection and effective legal remedies against the circumvention of effective [TPMs] that are used by authors, performers or producers of phonograms in connection with the exercise of their rights in, and that restrict acts in respect of, their works, performances, and phonograms, which are not authorized by the authors, the performers or the producers of phonograms concerned or permitted by law. ${ }^{386}$
}

The prohibition covers intentionally circumventing a TPM and providing to the public a device, product, or service as a tool of circumvention. ${ }^{387}$ The making, importation, or distribution of circumvention enabling tools (namely, a device, product, or a provision of service) is also prohibited where these tools are essentially made for the purpose of circumvention or have little commercial value other than when used in circumventing TPMs. ${ }^{388}$ A separate provision mandates the protection of RMI. ${ }^{389}$ These provisions are tempered by public interest safeguards, which require that the protection for TPMs and RMI be "without prejudice" not only to the "rights," but also the "limitations, exceptions, or defences to copyright or related rights infringement” under a member state's law, and that member states may subject the protection of TPMs and RMI to "appropriate limitations or exceptions."390

On Bill C-32's ISP provisions (and thus the identical provisions in Bill C-11), see Hagen, supra note 339. See Hamilton, supra note 312 (on ISP provisions under Bill C-60).

See Bill C-11 supra note 37, s 35, proposing s 31.1(1). See also Bill C-60, supra note 147, s 20 proposing s 31.1(1); Bill C-61, supra note 147, s 21, proposing s 31.1(1); Bill C-32, supra note 145, s 35, proposing s 31.1(1).

See Bill C-11, ibid, s 35, proposing s 31.1(3). See also Bill C-60, ibid, s 20, proposing s 31.1(2)-(3); Bill C-61, ibid, s 21, proposing s 31.1(2)-(3); Bill C-32, ibid, s 35, proposing s 31.1(3).

See Bill C-11, ibid, s 35, proposing ss 31.1(5)-(6). See also Bill C-60, ibid, s 20, proposing s 31.1(4)-(5); Bill C-61, ibid, s 21, proposing s 31.1(4)-(5); Bill C-32, ibid, s 35 proposing, s 31.1 (6).

See Bill C-11, ibid, s 47, proposing ss 41.25(1), 41.26(1). See also Bill C-60, ibid, s 29, proposing ss 40.1-40.2; Bill C-61, ibid, s 31, proposing ss 41.25-41.26; Bill C-32, ibid, s 47, proposing ss 41.25(1), 41.26(1).

See Bill C-11, ibid, s 47, proposing s 41.26(1)(b). See also Bill C-60, ibid, s 29, proposing s 40.2(1)(b); Bill C-61, ibid, s 31, proposing s 41.26(1)(b); Bill C-32, ibid, s 47, proposing s 41.26(1)(b).

ACTA, supra note 2, art 27.5 [footnote omitted].

Ibid, arts 27.6(a)(i)-(ii).

Ibid, arts 27.6(b)(i)-(ii).

Ibid, art 27.7.

Ibid, art 27.8. 
ACTA's inclusion of anti-circumvention obligations is notable, given that the WIPO Internet Treaties already provide an international legal framework for the protection of TPMs and RMI. ${ }^{391}$ However, ACTA's prohibitions against the circumvention of both types of TPMs (access-control and copy-control TPMs) and against the trafficking in circumvention tools go beyond the requirements of the WIPO Internet Treaties, which lack such obligations, at least explicitly. ${ }^{392}$

TPMs and RMI are particularly troubling for access to information because they can effectively convert the temporary copyright monopoly granted by the state to stimulate and reward the production and dissemination of intellectual works into perpetual property. ${ }^{393} \mathrm{At}$ the same time, they can limit the public's access to important safeguards and balancing mechanisms that are otherwise available within the Copyright Act, including defences and exceptions. Further, TPMs and RMI restrict the public's access to the public domain, which is a cornerstone of balancing under Canadian copyright law; works whose copyright term has expired may nevertheless not be accessible to the public because blunter technologies guarding the digital content may continue to restrict access past the expiration of the

WCT, supra note 66, art 11: "Contracting Parties shall provide adequate legal protection and effective legal remedies against the circumvention of effective technological measures that are used by authors in connection with the exercise of their rights under this Treaty or the Berne Convention and that restrict acts, in respect of their works, which are not authorized by the authors concerned or permitted by law" and art 12:

(1) Contracting Parties shall provide adequate and effective legal remedies against any person knowingly performing any of the following acts knowing, or with respect to civil remedies having reasonable grounds to know, that it will induce, enable, facilitate or conceal an infringement of any right covered by this Treaty or the Berne Convention:

(i) to remove or alter any electronic rights management information without authority;

(ii) to distribute, import for distribution, broadcast or communicate to the public, without authority, works or copies of works knowing that electronic rights management information has been removed or altered without authority.

(2) As used in this Article, "rights management information" means information which identifies the work, the author of the work, the owner of any right in the work, or information about the terms and conditions of use of the work, and any numbers or codes that represent such information, when any of these items of information is attached to a copy of a work or appears in connection with the communication of a work to the public.

See also WPPT, supra note 67, arts 18-19. For an article-by-article analysis of the WIPO Internet Treaties, see Mihály Ficsor, The Law of Copyright and the Internet: The 1996 WIPO Treaties, Their Interpretation and Implementation (Oxford: Oxford University Press, 2002) [Ficsor, The Law of Copyright and the Internet]. See also Jane Ginsburg, "Legal Protection of Technological Measures Protecting Works of Authorship: International Obligations and US Experience” (2005) Colum JL \& Arts 11; Mark Perry, “The Protection of Rights Management Information: Modernization or Cup Half Full?” in Michael Geist, ed, From "Radical Extremism" to "Balanced Copyright”: Canadian Copyright and the Digital Agenda (Toronto: Irwin Law, 2010) 304.

392 For an analysis of whether or not the WIPO Internet Treaties require prohibiting trafficking in circumvention tools, see Michael Geist, “The Case for Flexibility in Implementing the WIPO Internet Treaties: An Examination of the Anti-Circumvention Requirements” in Michael Geist, ed, From "Radical Extremism" to "Balanced Copyright": Canadian Copyright and the Digital Agenda (Toronto: Irwin Law, 2010) 204 at 207 [Geist, “The Case for Flexibility”] (arguing that the WIPO Internet Treaties have no "restrictions on the trafficking, distribution or marketing of circumvention tools or devices"); Ian R Kerr, Alana Maurushat, \& Christian S Tacit, "Technical Protection Measures: Tilting at Copyright's Windmill” (2003) 34:1 Ottawa L Rev 6 at 37 (stating that due to the flexibility of the anticircumvention provisions in the WIPO Internet Treaties "the form of legal protection could conceivably consist of a prohibition against acts of circumvention, a prohibition against trafficking in circumvention devices or a prohibition against both types of activities”); Ficsor, ibid at 549-50 (arguing that the member states of the WIPO Internet Treaties need to outlaw the trafficking of circumvention tools in order to comply with their obligations under the treaties). For an analysis of whether or not the WIPO Internet Treaties require the protection of both types of TPMs, see Ficsor, ibid at 550 (arguing that a country needs to provide protection for both types of TPMs in order to fulfil its TPM-related obligations under the WIPO Internet Treaties). See contra Geist, “The Case for Flexibility,” ibid at 212 (doubting that the protection of access-control TPMs is required by the WIPO Internet Treaties).

393 The rejection of the perpetual protection of copyright was confirmed by the House of Lords in England in the eighteenth century. Donaldson v Beckett (1774), 1 ER 837 (HL), 4 Burr 2408. 
copyright term, unless and until those technologies are circumvented. ${ }^{394}$ For the same reason, TPMs can render works inaccessible for legitimate uses permitted under Canadian copyright law, such as fair dealing, which the Supreme Court of Canada has emphasized is a user's right. $^{395}$

Anti-circumvention legislation, which protects the technological measures themselves from being circumvented, adds another layer of protection to the layers of protection already enjoyed by rights holders (namely, copyright law, contracts, and TPMs), which has made some commentators aptly describe it as "paracopyright." 396 Although anti-circumvention legislation can be drafted so as to exceptionally allow the circumvention of TPMs (or trafficking in circumvention tools) for fair dealing purposes, ${ }^{397}$ this would not render the anticircumvention legislation balance-oriented, but would merely make it less invasive to the principle of balance. Users would still incur the additional expense and effort of going through circumvention measures to enjoy their fair dealing rights, which is not in harmony with the Supreme Court of Canada's emphasis that users enjoy the status of rights holders in the Canadian copyright regime. ${ }^{398}$ Equally important, in light of the fact that copyrighted works are rapidly shifting to digital formats, making "exempted circumvention” the only way that TPM-protected digital works may be accessed after the copyright protection term has expired prejudicially imposes a formality, technical in nature, that must be satisfied before digital works that belong in the public domain are actually available in practice.

The WIPO Internet Treaties, to which Canada has been a signatory since 1997, already require the protection of TPMs and RMI. Both the WIPO Internet Treaties refer to "technological measures” without specifically distinguishing between "access” and "copy” control. ${ }^{399}$ Therefore, arguably legislative protection against circumvention of either copycontrol TPMs or access-control TPMs would satisfy the requirements of the WIPO Internet Treaties.

Théberge, supra note 148 at para 32: "Excessive control by holders of copyrights and other forms of intellectual property may unduly limit the ability of the public domain to incorporate and embellish creative innovation in the long-term interests of society as a whole, or create practical obstacles to proper utilization."

$395 \quad$ CCH, supra note 148 at para 48:

The fair dealing exception, like other exceptions in the Copyright Act, is a user's right. In order to maintain the proper balance between the rights of a copyright owner and users' interests, it must not be interpreted restrictively. As Professor Vaver [David Vaver, Copyright Law (Toronto: Irwin

Law, 2000)] has explained, at p. 171: "User rights are not just loopholes. Both owner rights and user rights should therefore be given the fair and balanced reading that befits remedial legislation." See Dan L Burk, “Anticircumvention Misuse” (2003) 50 UCLA L Rev 1095 at 1096; Ian R Kerr, "If Left to Their Own Devices: How DRM and Anti-circumvention Laws Can Be Used to Hack Privacy" in Michael Geist, ed, In The Public Interest: The Future of Canadian Copyright Law (Toronto: Irwin Law, 2005) 167 at 169.

397 The national implementation of treaties' requiring the protection of TPMs and RMI, such as the WIPO Internet Treaties, in some foreign jurisdictions shows that providing protection for TPMs and RMI while considering users rights is not an easy task. See Pamela Samuelson, Jerome H Reichman \& Graeme Dinwoodie, "How to Achieve (Some) Balance in Anti-Circumvention Laws" (2008) 51:2 Communications of the ACM 12 at 21 (arguing that while the WIPO Internet Treaties reflected a negotiated balance between authors and users of copyrighted digital works, the national implementation of the treaties' anti-circumvention provisions in US and EU law has been imbalanced, which harms the legitimate interests of users). Furthermore, in Canada, neither Bill C-11, supra note 37, nor Bill C-61, supra note 147, allow circumvention for fair dealing purposes. Bill C-60, supra note 147, on the other hand, provided remedies against circumvention for the purpose of infringing copyright or moral rights. Bill C-60, ibid, s 27, proposing s 34.02(1). However, Bill C-60 did not allow circumvention for the purpose of private copying. Bill C-60, ibid, s 27, proposing s 34.02(1). 
ACTA, however, imposes distinct obligations in this area, which are more stringent than those under the WIPO Internet Treaties. ACTA mandates in Article 27.5 that members provide "adequate legal protection and effective legal remedies against the circumvention of effective technological measures." ${ }^{400}$ Article 27.6 then provides that, in order to effectuate that mandate, members shall provide protection "at least” against (1) "unauthorized circumvention of an effective technological measure"; ${ }^{401}$ (2) offering the public a device or service as a means to circumvent an effective TPM; ${ }^{402}$ and (3) making, importing, or distributing a device or product or providing a service that is "primarily designed or produced" to circumvent an effective TPM or which has "only a limited commercially significant purpose other than circumventing an effective" TPM. ${ }^{403}$ ACTA hence imposes three obligations: anti-circumvention of TPMs, prohibiting offering devices or services to circumvent TPMs, and prohibiting trafficking in circumvention tools or services. In addition, Article 27.7 provides separate protection for electronic RMI by mandating that each member provide “adequate legal protection and effective legal remedies against” (1) removing or altering electronic RMI; ${ }^{404}$ and (2) distributing, importing, or making available to the public copies of works where the electronic RMI has been removed or altered without authorization. ${ }^{405}$ The requisite knowledge under Article 27.7 includes any person who, without authorization, performs those acts with knowledge (or for civil remedies, having reasonable grounds to know) that it will "induce, enable, facilitate, or conceal an infringement of any copyright or related rights."

Canada's Bill C-11, the Copyright Modernization Act, which was in part designed to ratify the WIPO Internet Treaties, adds several protections for TPMs and RMI. ${ }^{407}$ This section examines Bill C-11's provisions on TPMs and RMI and assesses whether they comply with ACTA's obligations.

ACTA, supra note 2, art 27.5.

Ibid, art 27.6(a)(i).

Ibid, art 27.6(a)(ii).

Ibid, art 27.6(b).

Ibid, art 27.7(a).

Ibid, art 27.7(b).

Ibid, art 27.7.

It has been argued that even before Bill C-11, Canada satisfied the requirements of the anticircumvention provisions of the WIPO Internet Treaties by virtue of the combined provisions in the Copyright Act, supra note 1, Radiocommunication Act, RSC 1985, c R-2, and/or Criminal Code, supra note 295; see Christian S Tacit, "The Current Status of Legal Protection for Technology Protection Measures in Canada,” online: Canadian Heritage <http://www.pch.gc.ca/>. Several arguments were raised against the introduction of an anti-circumvention law in Canada. See e.g. Jeremy F deBeer, "Constitutional Jurisdiction Over Paracopyright Laws" in Michael Geist, ed, In The Public Interest: The Future of Canadian Copyright Law (Toronto: Irwin Law, 2005) 89 (discussing whether the Canadian Federal government is empowered under the Constitution to enact a law protecting TPMs and RMI, since TPMs and RMI touch upon many issues, such as property and consumer protection, the regulation of which is reserved to the provincial and territorial legislatures); Michael Geist, "Anti-Circumvention Legislation and Competition Policy: Defining a Canadian Way?” in Michael Geist, ed, In The Public Interest: The Future of Canadian Copyright Law (Toronto: Irwin Law, 2005) 211 at 250 (arguing that an anti-circumvention legislation "risks turning the exercise of copyrights into anti-competitive behaviour”); Jane Bailey, "Deflating the Michelin Man: Protecting Users’ Rights in the Canadian Copyright Reform Process” in Michael Geist, ed, In The Public Interest: The Future of Canadian Copyright Law (Toronto: Irwin Law, 2005) 125 at 166 (arguing that an anti-circumvention law will "deepen" the restrictions on free expression already existing under Canadian copyright law); Kerr, supra note 396 (arguing that TPMs and anti-circumvention laws that don't address the privacy implications of TPMs pose a threat to privacy rights); Michael Geist, “'TPMs’: A perfect storm for consumers” (30 January 2005), online: Michael Geist <http://www.michaelgeist.ca/ content/view/1698/78/> (arguing that the protection of TPMs threatens the principle of balance embraced by the Supreme Court of Canada). 
First, with respect to ACTA's anti-circumvention provisions, members are required to prohibit the circumvention of “effective” TPMs used in association with authors' works, performers' performances, and producers' phonograms to protect these works against acts unauthorized by the rights holders or law. ${ }^{408}$ Both types of TPMs-access-control and content-control TPMs - by virtue of the definition of "effective" are included in ACTA's general anti-circumvention prohibition. According to ACTA, a TPM is "effective” where the "use of protected works, performances, or phonograms is controlled by authors, performers or producers of phonograms through the application of a relevant access control or protection process, such as encryption or scrambling, or a copy control mechanism, which achieves the objective of protection." 409

To comply with ACTA, legislation must either protect both copy- and access-control TPMs against circumvention, or protect only access-control TPMs, providing that the latter option can be justified on the grounds that an access-control TPM will effectively provide copycontrol protection since an access-control TPM would first have to be circumvented before the protected work or related rights subject matter could be copied. On the other hand, it would be difficult to argue that providing protection against the circumvention of only copycontrol TPMs would satisfy ACTA's obligations. Bill C-11, prohibits the circumvention of only access-control TPMs guarding a work, performer's performance fixed in a sound recording, or sound recording. ${ }^{410}$ Although Bill C-11 does not protect copy-control TPMs against circumvention, even those who have argued that the WIPO Internet Treaties require both copy-control and access-control TPMs to be protected have been satisfied that Bill C11's provisions comply with the WIPO Internet Treaties. ${ }^{411}$ However, Bill C-11's anticircumvention provisions also have a significant deleterious implication for users' rights. Unlike a previous bill, which provided a remedy only to those circumventions made for the purpose of infringing the copyright or moral rights in the work, performer's performance

ACTA, supra note 2, art 27.5.

Ibid, art 27.5, n 14 [emphasis added].

See Bill C-11, supra note 37, s 47, proposing s 41.1(1)(a). Bill C-11 defines technological protection measures as any "effective technology, device or component" that either (a) controls access to a copyrighted work or protected performance or sound recording whose use is authorized by the rightsholder (i.e. an access-control TPM) or (b) restricts a protected act such as the economic rights in ss 3, 15, or 18 and the remuneration right in section 19 (i.e. a copy-control TPM). Bill C-11, ibid, s 47 proposing s 41, sub verbo "technological protection measure" (a) and (b). Bill C-61, supra note 147, similarly prohibited the circumvention of only access-control TPMs protecting a work, performer's performance fixed in a sound recording or sound recording. See Bill C-61, ibid, s 31, proposing s 41.1(1)(a). Bill C-61's definition for TPMs in section 41 was identical to the one in Bill C-11. By contrast, Bill C-60, supra note 147, provided remedies against the circumvention of only copy-control TPMs protecting a work, performer's performance fixed in a sound recording or sound recording. Bill C-60, ibid, s 27 proposing s 34.02(1). Bill C-60, ibid, s 2, proposing s 2 defines TPMs as "any technology, device or component that, in the ordinary course of its operation, restricts the doing - in respect of a material form of a work, a performer's performance fixed in a sound recording or a sound recording - of any act that is mentioned in section 3, 15 or 18 or that could constitute an infringement of any applicable moral rights."

See e.g. Ficsor, supra note 391 at 550 (arguing that the WIPO Internet Treaties require member states to provide anti-circumvention protection for both types of TPMs in order to fulfil their TPM-related obligations under the WIPO Internet Treaties). Compare Mihály Ficsor, "TPMs and Flexibility ('The Ability of Bending Without Breaking') — Why Should the TPM Provisions of Bill C-32 Protect Access Controls and Prohibit 'Preparatory Acts'” (15 November 2010) at 4, 47, online: IP Osgoode <http://www.iposgoode.ca/Ficsor-TPMs-and-Flexibility.pdf> (arguing that the WIPO Internet Treaties require the protection of both types of TPMs (as well as the prohibition of "preparatory acts" (manufacturing and distributing "protection-defeating devices”), yet concluding that Bill C-32 (and thus Bill C-11) is treaty compliant). 
fixed in a sound recording, or sound recording to which the TPMs are attached, ${ }^{412}$ Bill C-11 is not subject to such an important condition. It would be preferable to amend Canada's Copyright Act to prohibit circumvention only where it is done for the purpose of infringing copyright or moral rights. Narrowing the prohibition in this manner both saves users' rights, such as fair dealing and private copying, and complies with the underlying purpose for protecting TPMs, which is to combat copyright infringement. Such a condition would also still comply with ACTA since the agreement does not require anti-circumvention protection where access or copying of the protected subject matter is allowed by law. ${ }^{413}$ Such a reform could be implemented when a subsequent bill addressing ACTA's enforcement obligations is tabled.

Second, with respect to ACTA's prohibition on providing a service that will circumvent effective TPMs, Bill C-11 prohibits offering or providing circumvention services to the public if these services are mainly targeting circumventing TPMs, if they are marketed as such, or if they have no commercial value other than when used for the purpose of circumventing TPMs. ${ }^{414}$ However, a more limited provision, in which the Copyright Act prohibited providing or offering circumvention services only where the provider knows or ought to know that circumvention will result in copyright or moral rights infringement would have been preferable. ${ }^{415}$ The latter narrower mode of protection is more respectful of users' rights and yet is still compliant with ACTA since Article 27.8 allows member states to have "appropriate limitations or exceptions" to the implementation of the anti-circumvention provisions of ACTA. ${ }^{416}$

Third, with respect to ACTA's prohibition against trafficking in anti-circumvention devices, products, or services, Bill C-11prohibits dealing with circumvention technologies, tools, and components, by means of manufacturing, importing, distributing, offering for sale or rent, or providing (including by selling or renting), in three cases: (1) when the technology, device, or component is mainly made for the purpose of circumventing TPMs; (2) if it is marketed as such; or (3) if it has no significant value but for the purpose of circumventing TPMs. ${ }^{417}$ In these provisions, Bill C-11 makes no distinction between accesscontrol and copy-control TPMs. These provisions satisfy ACTA's requirement to prohibit trafficking in circumvention devices and tools. Nevertheless, here too it would be preferable to have limited the prohibition to cover trafficking in circumvention devices only where it is for the purpose of infringing copyright or moral rights so as to give effect to users' rights and to avoid any chilling effect on cryptography research.

( remedies against someone who circumvented a TPM to make a private copy under s 80(1) of the Copyright Act, supra note 1. Bill C-60, ibid, s 27, proposing s 34.02(1).

ACTA, supra note 2, art 27.8.

Bill C-11, supra note 37, s 47, proposing s 41.1(1)(b). See also the similar provision in Bill C-61, supra note 147, s 31, proposing s 41.11(1)(b).

By contrast to Bill C-11, Bill C-60's remedies against providing or offering services to circumvent TPMs applied only if the provider knew or should have known that providing that service would lead to copyright or moral rights infringement. Bill C-60, supra note 147, s 27, proposing s 34.02(2). ACTA, supra note 2.

Bill C-11, supra note 37, s 47, proposing s 41.1(1)(c). See also similar provisions in Bill C-61, supra note $147, \mathrm{~s} 31$, proposing s $41.11(1)(\mathrm{c})$. 
Importantly, though, Bill C-11 does incorporate additional safeguards, which ACTA expressly permits in Article 27.8. Bill C-11 has a bundle of exceptions pertinent to circumvention activities and to trafficking in circumvention-enabling tools. These exceptions are solely for the limited purposes of facilitating law enforcement investigations and the protection of national security; making computer programs interoperable; doing encryption research; verifying and preventing the unauthorized collection of personal information; testing the reliability of the security of a computer, computer system, or computer network and fixing their flaws; making the work perceptible to a person with a perceptual disability; gaining access to a telecommunications service through the radio; and making an ephemeral recording of protected work or subject matter in a broadcasting undertaking. ${ }^{418}$ Some exceptions are absolute, such as the ones pertaining to law enforcement, while other exceptions do not apply in certain contexts, namely, when they involve acts that may constitute copyright infringement or a violation of any federal or provincial law, ${ }^{419}$ when they render the TPM "unduly impair[ed]," ${ }^{220}$ when they are done without the permission of the owner of the work or without the consent of the owner or administrator of the computer system, ${ }^{421}$ or when the individual benefiting from the exception has obtained the TPMprotected subject matter unlawfully. ${ }^{422}$

These exceptions to the prohibitions against circumvention of TPMs and trafficking in circumvention-enabling services and tools, taken with their constraints, comply with ACTA's anti-circumvention provisions, which already allow member states to subject the protection of TPMs against circumvention to "appropriate limitations or exceptions." ${ }^{\text {"23 }}$ In fact, ACTA is more permissive than Bill C-11. Whereas ACTA provides that the obligations to protect TPMs are without prejudice to the "rights, exceptions, limitations, or defences" already established in member states' copyright laws, and that a member state "may adopt or maintain appropriate limitations or exceptions" to the implementation measures, ${ }^{424}$ the exceptions provided in Bill C-11 do not allow TPMs to be circumvented for purposes otherwise allowed by Canadian copyright law, such as for fair dealing or private copying. This omission in Bill C-32 triggered Canadian calls to reform these provisions to include an exception allowing circumvention for purposes serving the public interest, such as fair dealing, but this change was not made in Bill C- $11 .^{425}$ Such a serious shortcoming could be overcome in a subsequent bill to address ACTA's enforcement obligations by adding an exception to allow circumvention for purposes allowed by copyright law, such as fair dealing and private copying, which would protect users' rights under copyright law, and by adding

Bill C-11, ibid, s 47, proposing ss 41.11-41.18. See also similar provisions in Bill C-61, ibid, s 31, proposing ss 41.11-41.17.

Bill C-11, ibid, s 47, proposing ss 41.12(6)-(7), 41.13(2). See also similar provisions in Bill C-61, ibid, ss 41.12(6)-(7), 41.13(2).

Bill C-11, ibid, s 47, proposing ss 41.16(2), 41.14(2). See also similar provisions in Bill C-61, ibid, s 31, proposing ss $41.14(2), 41.16(2)$.

Bill C-11, ibid, s 47, proposing ss 41.13(1)(c), 41.15(1). See also similar provisions in Bill C-61, ibid, s 31, proposing ss $41.13(1)(C), 41.15(1)$.

Bill C-11, ibid, s 47, proposing s 41.13(1)(b). See also similar provisions in Bill C-61, ibid, s 31, proposing s $41.13(1)(\mathrm{b})$.

ACTA, supra note 2 , art 27.8 .

Ibid.

See Carys Craig, "Locking Out Lawful Users: Fair Dealing and Anti-Circumvention in Bill C-32” in Michael Geist, ed, From "Radical Extremism" to "Balanced Copyright": Canadian Copyright and the Digital Agenda (Toronto: Irwin Law, 2010) 177; Michael Geist, “ACTA Conclusion Leaves Flexibility for Made-in-Canada Approach” (12 October 2010), online: Michael Geist <http://www.michaelgeist. ca/content/view/5368/135/>. 
a clarification that the prohibition on circumvention does not obviate rights users may have under other bodies of law, such as contract, privacy, or consumer protection laws. Alternatively and preferably, rather than expand the exceptions, the prohibition on circumvention could itself be narrowed to apply only when circumvention is for the purpose of infringing copyright or moral rights.

As to remedies, ACTA's final text obliges member countries only to provide "adequate legal protection and effective legal remedies," ${ }^{26}$ although earlier drafts of ACTA had included wording proposing the establishment of both civil and criminal liability against circumvention-based prohibitions. ${ }^{427}$ Bill C-11 goes beyond the requirements of ACTA by providing both civil and criminal remedies against individuals involved in the prohibited circumvention activities. Specifically, a rights holder is entitled to all remedies available under the law for copyright infringement against an individual who circumvented an accesscontrol TPM, ${ }^{428}$ except that statutory damages could not be claimed against an individual who circumvented an access-control TPM for personal use. ${ }^{429}$ Nevertheless, all remedies, including statutory damages, are available against individuals trafficking in anticircumvention enabling tools or services. ${ }^{430}$ As to innocent infringers, a court may reduce the damages awarded against individuals who satisfy the court that they were unaware or did not have reasonable grounds to know that their acts were prohibited by these sections. ${ }^{431}$ Where the defendant is a library, archive, or a museum and convinces the court that it did not know or have reasonable grounds to know that its activities were infringing, the only remedy available for the plaintiff is injunction. ${ }^{432}$ Individuals acting on behalf of these institutions are not subject to the criminal liability described. ${ }^{433}$ However, Bill C-11 subjects persons intentionally circumventing TPMs for commercial purposes to criminal penalties that may reach up to $\$ 1$ million and/or imprisonment for five years. ${ }^{434}$ Bill C-11's provisions on remedies are compliant with $A C T A$. However, given that $A C T A$ does not require that criminal sanctions be imposed for all circumvention-based prohibitions, and that as a general policy criminal liability should not be unduly extended to new offences, it is recommended that a subsequent copyright reform bill make it a criminal offense to circumvent a TPM only where it is for the purpose of copyright infringement, which is consistent with ACTA's obligation to criminalize the aiding and abetting of copyright infringement. ${ }^{435}$

ACTA, supra note 2, art 27.5.

See e.g. ACTA: April 2010 Consolidated Text, supra note 14, ch 2, s 4, art 2.18(4).

Bill C-11, supra note 37, s 47, proposing s 41.1(2). See also the similar provisions in Bill C-61, supra note 147, s 31, proposing s 41.1(2).

Bill C-11, ibid, s 47, proposing s 41.1(3). See also the similar provisions in Bill C-61, ibid, s 31, proposing s 41.1(3).

Bill C-11, ibid, s 47, proposing s 41.1(4). See also the similar provisions in Bill C-61, ibid, s 31, proposing s 41.1(4).

Bill C-11, ibid, s 47, proposing s 41.19. See also the similar provisions in Bill C-61, ibid, s 31, proposing s 41.18.

Bill C-11, ibid, s 47, proposing s 41.2 See also the similar provisions in Bill C-61, ibid, s 31, proposing s 41.19 .

Bill C-11, ibid, s 48, proposing s 42(3.1). See also the similar provisions in Bill C-61, ibid, s 32, proposing s 42(3.1).

Bill C-11, ibid, s 48, proposing s 42(3.1). See also the similar provisions in Bill C-61, ibid, s 31, proposing s 42(3.1). Although Bill C-60 made all remedies available against a person circumventing a TPM for the purpose of infringing copyright or moral rights, or offering or providing circumvention services for the same purpose, Bill C-60 did not make it a criminal offence to circumvent a TPM for infringement purposes. See Bill C-60, supra note 147, s 27, proposing s 34.02(1)-(2).

ACTA, supra note 2, art 23.4. 
Finally, ACTA also prohibits the circumvention of RMI and prohibits the circulation of works where the RMI has been removed or altered without authority. ${ }^{436}$ Bill C-11 satisfies ACTA by including both provisions protecting RMI and remedies for contravening these provisions. Bill C-11 prohibits intentionally altering or removing "rights management information ... without the consent of the owner of the copyright in the work," 437 if the person knew or should have known that these actions would facilitate or conceal copyright infringement or harm the right to equitable remuneration for public performance and communication to the public under Section $19 .{ }^{438}$ Bill C-11 makes anyone liable who knowingly and without the owner's consent sells, rents, distributes with a prejudicial effect on the owner, offers for sale or rental, or imports into Canada for one of these purposes, or communicates to the public by telecommunication, a work in which the rights management information has been removed or altered. ${ }^{439}$

Under Bill C-11, the owner of a copyrighted work whose RMI has been removed or altered is entitled to all copyright infringement remedies, such as injunctions, damages, and delivery up, against defendants who knowingly, and without authorization from the copyright owner, have removed or altered the RMI in a copyrighted work. ${ }^{440}$ The same remedies are available against defendants who knowingly distribute, sell, or rent, or import into Canada for one of these purposes, or communicate to the public by telecommunication a copyrighted work in which the RMI has been removed or altered. ${ }^{441}$

\section{CONCLUSION}

ACTA is the most recent example of an intellectual property agreement supported by industrial countries to expand the protection and enforcement of intellectual property rights. The final outcome of the ACTA negotiations moderated or removed many of the most controversial provisions in the agreement, which has alleviated much of the concern that the agreement would impose obligations that are in tension with principles of Canadian copyright law. Canada has taken significant steps toward ratifying ACTA with Bill C-11, the Copyright Modernization Act. However, further legislative changes will be necessary before

"Rights management information" is defined as information that

(a) is attached to or embodied in a copy of a work, a performer's performance fixed in a sound recording or a sound recording, or appears in connection with its communication to the public by telecommunication; and

(b) identifies or permits the identification of the work or its author, the performance or its performer, the sound recording or its maker or the holder of any rights in the work, the performance or the sound recording, or concerns the terms or conditions of the work's, performance's or sound recording's use.

Bill C-11, supra note 37, s 47, proposing s 41.22(4). See also the similar definitions in Bill C-61, supra note 147, s 31, proposing s 41.21(4) and Bill C-60, supra note 147, s 2, proposing ss 2(a)-(b). On rights management information, see Perry, supra note 391.

Bill C-11, ibid, s 47, proposing s 41.22(1). See also the similar provision in Bill C-61, ibid, s 31, proposing s 41.21(1). With a slight variation, Bill C-60 provided remedies for altering or removing "rights management information," without the consent of the owner of the copyright in the work, if the person knew or should have known that the removal or alteration would facilitate or conceal copyright infringement. Bill C-60, ibid, s 27, proposing s 34.01(1). Bill C-11, ibid, s 47, proposing s 41.22(3). See also the similar provision in Bill C-60, ibid, s 27, proposing s 34.01(2); Bill C-61, ibid, s 31, proposing s 41.21(3). Bill C-11, ibid, s 47, proposing s 41.22(2). See also the similar provisions in Bill C-60, ibid, s 27, proposing s 34.01(1); Bill C-61, ibid, s 31, proposing s 41.21(2).

441 Bill C-11, ibid, s 47 proposing s 41.22(3). See also the similar provisions in Bill C-60, ibid, s 27, proposing s 34.01(2); Bill C-61, ibid, s 31, proposing s 41.21(3). 
Canada will be in compliance with all of the agreement's mandatory provisions on intellectual property enforcement, including those pertaining to copyright.

In considering a prospective bill on intellectual property rights enforcement to satisfy ACTA's obligations, Parliament should place appropriate emphasis on the many safeguards that have been included in ACTA and be mindful that these are not always reiterated in the agreement's specific provisions. The safeguards with application to copyright include: ${ }^{442}$

- the Preamble’s instruction, with particular emphasis on copyright and related rights, to balance "the rights and interests of the relevant right holders, service providers, and users"; 443

- $\quad$ Article 1's explicit statement that ACTA shall not derogate from a member's obligations under any other existing agreement including TRIPS ${ }^{444}$ (and thus that TRIPS's safeguards continue to bind ACTA members and non-ACTA countries that are members of the WTO);

- $\quad$ Article 2.3's adoption of the objectives and principles in TRIPS Part I, which includes the flexibilities in TRIPS Articles 7 and $8^{445}$ (namely, stating that the "protection and enforcement of intellectual property rights should contribute to the promotion of technological innovation and to the transfer and dissemination of technology to the mutual advantage of producers and users ... and in a manner conducive to social and economic welfare, and to a balance of rights and obligations"; ${ }^{446}$ providing that members may adopt measures consistent with TRIPS that are "necessary to protect public health and nutrition, and to promote the public interest in sectors of vital importance to their socio-economic and technological development”; ${ }^{447}$ and acknowledging that appropriate measures consistent with TRIPS may be needed to prevent rights holders' abuse of intellectual property rights, unreasonable restraint of trade, or adverse effects on international transfer of technology); ${ }^{448}$

- $\quad$ Article 4's affirmation that the agreement preserves legal protections for privacy and confidential information; ${ }^{449}$

- Article 6.2's procedural safeguards, which apply generally to enforcement, specifically that procedures to implement the agreement be fair and equitable, appropriately protect the rights of all participants subject to the procedures, and not

There are other safeguards that are more applicable to other intellectual property rights, for example, the Preamble's recognition of the principles in the Doha Declaration on TRIPS and Public Health, supra note 248, which has a bigger effect on patent and trademark rights (ACTA, supra note 2, Preamble, para 9). 
be unnecessarily complicated or costly or entail unreasonable time limits or unwarranted delays; $; 50$

- Article 6.3's general obligation with respect to enforcement to take the proportionality principle into account; ${ }^{451}$

- $\quad$ Articles 13, 27.2, 27.3, and 27.4 on avoiding creating barriers to legitimate trade $\mathrm{e}^{452}$ (which is also stated in the Preamble); ${ }^{453}$

- $\quad$ Articles 27.2, 27.3, and 27.4 on preserving fundamental principles such as freedom of expression, fair process, and privacy; ${ }^{454}$

- $\quad$ Article 27.8 allowing members to “adopt or maintain appropriate limitations or exceptions to measures implementing” protections for TPMs and RMI and that the TPM and RMI obligations are "without prejudice" to rights as well as "limitations, exceptions, or defences to copyright or related rights infringement” in a member's law. ${ }^{455}$

Canadian copyright law was already compliant with many of the requirements in ACTA when the agreement was signed in October 2011 and has made further steps toward satisfying those obligations with the digital copyright amendments in Bill C-11. Specifically, that legislation satisfies ACTA's obligation to provide anti-circumvention protection to both types of TPMs (or at least access-control TPMs) and RMI and to prohibit trafficking in circumvention tools and services. Indeed, Bill C-11's method of implementing this new layer of protection surpasses ACTA's requirements in some aspects. To alleviate the impact of this new layer of protection on the delicate balance of copyright, while still complying with ACTA, it is recommended that circumvention (and trafficking in its tools and services) be prohibited only where it is done for the purpose of infringing copyright or moral rights. Alternatively, if Bill C-11's structure of a broad prohibition on circumvention coupled with a list of exceptions is retained, it is recommended that the list of exceptions be expanded to allow circumvention for purposes that are rendered non-infringing by exceptions or other regimes under copyright law (such as fair dealing and private copying) and to clarify that nothing in the prohibition on circumvention affects rights that users may have under other bodies of law, such as contract, privacy, or consumer protection laws.

Even after the passage of Bill C-11, it will still remain to increase border enforcement powers before Canada will have satisfied ACTA's copyright obligations. Under ACTA, Canadian border authorities would have to be provided with ex officio power to seize goods allegedly infringing copyright. This change would authorize customs officials to determine whether or not the seized goods are copyright infringing. Given the complexity of that inquiry and the level of knowledge and training required to reach an accurate determination,

Ibid, art 6.2

Ibid, art 6.3 .

Ibid, arts 13, 27.2-27.4.

Ibid, Preamble, para 5.

Ibid, arts 27.2-27.4.

Ibid, art 27.8 . 
this type of determination is more appropriate for a court than customs officials, and thus we caution that appropriate procedural safeguards need to be included along with the increased authority, including a timely right to raise exceptions and defences under the Copyright Act. Finally, to fully comply with ACTA's obligations to criminalize aiding, enticing, and abetting copyright infringement, the scope of the actions that constitute aiding, enticing, and abetting copyright infringement may also need to be expanded through amendments to either the Copyright Act or the Criminal Code. 